386
T23ó
cop.2

\title{
GARAY
}

ACOOUNT DE THE ISTHMUS

AF TEHLANTEFEC. 



\section{ISTHMUS OF TEHUANTEPEC.}





\section{A N A C COU N T}

OF THE

\section{ISTHMUS OF TEHUAN'TEPEC}

IN THE REPUBLIC OF MEXICO ;

WITH PROPOSALS FOR

ESTABLISHING A COMMUNICATION

BETWEEN

\section{THE ATLLANTIC AND PACIFIC OCEANS,}

BASED UPON THE SURVEYS AND REPORTS OF A SCIENTIFIC COMMISSION,

\section{APPOINTED BY THE PROJECTOR}

DON JOSÉ DE GARAY

\section{O N DON :}

PRINTED BY J. D. SMITH AND CO.,

7, EAST HARDING STREET, GOUGH SQUARE, FLEET STRE.T. 1846. 


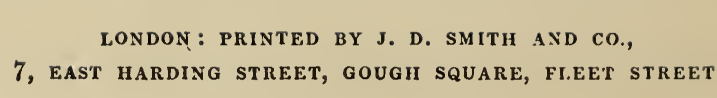




\section{CONTEN'I'S.}

PAGE.

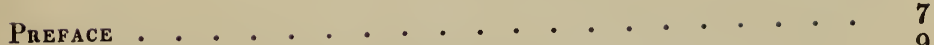

INTRODUCTION

CHAP. I.

Advantages of an Oceanic Communication through the AmeRICAN ISTHMUS, AND PREFERENCE Which OUGHT TO BE GIVEN TO the Territory of Tehuantepec over those of Panama and Nicaragua . . . • • • • • • • . • • • • • •

CHAP. II.

The Isthuus of Tehuantepec had been decreed to be opened by the Spanish Cortes, 30 April, 1814. Proposals of Don José de Garay to the Mexican Government, and terms of the grants made to him.-Scientific Commission of Survey appointed by Don J. de Garay,--departure of the Commission from Mexico,-motives of Confidence to be placed in the Reports of the Commission . .

\section{CHAP. III.}

Notices of different Authors, ancient and modern, who have spoken of the Isthmus of Tehuantepec,-Cortes,-Dampier,-Cramer,Humboldt, 一Robinson,-Tadeo de Ortiz,-Orbegoza . • .

\section{CHAP. IV.}

Proceedings of the Commission of survey of the Isthmus, measurement of a base line on the beach between St. Mateo and Santa Maria.-Examination of the district of Tehuantepec,--Las Ventosas and near the Morro unfit for Anchorages,-trigonometrical operations at San Dionisio, Camotepec, and Juchitan.Examination of the Upper and Lower Lagoons,-the Bocabarra, 
- the river Ostuta,-its waters to feed the proposed Canal, - the ground north of Chivela, Guichicovi, and Boca de Monte,-first sight of the Coatzacoalcus at Mal Paso, its transparency, firm Clay banks, slow current, - -its borders lined with thick woods.-Excursion down its course to its mouth,-weather then unfavorable for observations.-Visit to Acayucam,-the Jumuapa.-Return to Tarifa,-Venta de Chicapa,-ground examined from San Miguel to the river del Corte,- the Upper Coatzacoalcos.-Cerro de Albricias, - the view from this fixes the choice for the passage of the Canal over the Gap of Tarifa,-its minute description.Departure of Capts. Robles and Gonzales to survey the Coatzacoalcos,-the river Chicapa.-Tarifa and the Ultimo Rancho have the same level.-Volume of the waters of the Chicapa below its junction with the Monetza.-Cerro del Convento.- Source of the Monetza and river at Tarifa, same level,-also the Portillo; - the Ostuta examined and practicability of joining its waters by a conduit to those of the Chicapa.-Capt. Robles completes the survey of the lower Coatzacoalcos, and examines the upper waters to the Sarabia.-Sr. Moro explores the ground from Tarifa to the confluence of the Malatengo with the Coatzacoalcos, also from Tarifa to the Rio del Corte.-Re-inspection of the proposed line of Conduit for the joint waters of the Ostuta and Chicapa to Tarifa by Messrs. Moro and Robles and their confirmation of its practicability,-final return of the Commission to Tehuantepec, the exploration of the Isthmus being completed . . . . . . . .

\section{CHAP. V.}

Survey of the Coatzacoalcos, rises in the Sierra Madre-examined from the confluence of the Chimalapilla all the way to tlie sea.The streams of importance are, (on the right bank), the Chimalapilla,-del Pinal,-Chalchijapa,-at the Horqueta the right branch is called Apotzongo-branches re-uuite near the Rancho del Mariscal-Coachapa-Uspanapan-Creek Coatajapa and several useful Lagoons-(left bank) the Milagro-Escolapa-Malatengo - Sarabia-Jumuapa-Jaltapec-the Naranjo and Penas Blancas - the river divides at the Horqueta; to the left is the Mistan forming the Island of Tacamichapa-Creeks, Tacojalpa, Ojazapa, Cuamecatan, and 'Tacateno-the river Calzadas-which branches off and enters the sea at the Barilla-'The borders of the Coatzacoal$\cos$ and its tributaries covered with dyewoods, mahogany and other fine trees and forests of timber fit for ship-building-the Upper Coatzacoalcos abounds in lofty pine trees-Coatzacoalcos navigable for the largest ships for $34 \frac{1}{2}$ miles-the bar does not shift, and leaves two entrances- has 201 feet over its western passageThis Hakbour the finest in the Gulf of Mexico . . . . .

CHAP. VI.

Statistical notes of the Istmius of Tehuantepec.

Southern division in the department of Oajaca-the northern in that of Vera Cruz-Inhabitants-Climate-Minerals-VegetablesAnimals-Agriculture-Cattle-Salt-Industry-Antiquities . 


\section{CHAP. VII.}

Projects.

PAGE.

Correction and clearance of the course of the Coatzacoalcos-closing the entrance of the Mistan-Clearing entrance to the Bocabarradeepening the Channels of the Lagoons-first project-Waters of the Ostuta and Chicapa led by watercourses to Tarifa-summit level between the Monetza and Tarifa-line of cutting on both sides, through argillaceous rocks, marl, clay, sands, and slatessecond project-to the Portillo the summit level and descent to the Chicapa using its Channel.- Third project-summit level at Tarifa, thence by the beds of the Chichihua and Malatengo to the Coatzacoalcos; and by the Monetza and Chicapa to the Lagoons .

\section{CHAP. VIII.}

\section{Estimates of Expenses.}

All materials upon the spot-calculations based on the first projectCaledonian Canial taken as the model-cost of 120 locks- 50 miles of Canal-watercourses of 18 miles between the Ostuta and TarifaCorrection of the Coatzacoalcos-total calculated cost $£ 3,380,000$. - Sales of lands and produce will aid in carrying on the workprovisional train and railways during the formation of the Canal.

\section{CHAP. IX.}

\section{Estimate' of Returns.}

The Isthmus the nearest unoccupied tropical Country to Europethe nearest and safest route to the Pacific and Chinese seas- the voyages to the West coast of America shortened by 6500 to 12,000 miles-Enumeration of the products of the Isthmus-privileges of Colonists-steam navigation and Coals-Salt-Free Laborers-Commercial movement round Capes Horn and Good Hope-transit dues-produce of Land-Steam navigation-dyewoods, timber, and fine woods-value of other articles-total annual receipts on the completion of the communication calculated at $£ 1,200,000$.- Extract from a Report made to the Congress of the United States in 1839

\section{APPENDIX.}

No. 1. Memorial of Don José de Garay soliciting the privilege of opening a communication between the Atlantic and Pacific Oceans through the Isthmus of Tehuantepec. . . . . . . .

No. 2. Edict ordering the opening of the Isthmus with the grants therein specified, and Contract between the supreme government and Don José de Garay. . . . . . . . . . . . .

No. 3. Deeree by which the government declares that all lands granted previous to the decree of the 1st of March, both to Natives and Foreigners, and which are neither tenanted, nor cultivated, belong to Don José de Ga”ay. . . . . . . . . . . . 
No. 4. Communication from Don Jose de Garay, informing the supreme Government that the survey of the Isthmus was concluded, - and answer to the same from the goverument. . . . 108

No.5. Decree granting to Don José de Garay, the term of a year, according to his request for the commencement of the works. . . 109

A.

\section{OBSERVATIONS.}

Table I. Latitudes astronomically determined .

, 2. Geographical positions of the principal points of the Triangulation . . . . . . . . . . . . . . ib.

Table 3. Altitudes from Trigonometrical measurements . . . 113

"4. Barometrical altitudes . . . . . . . . . . ib.

" 5. Heights above the level of the sea on the road from Teluantepec to Puebla . . . . . . . . . . 114

B.

GEOLOGY.

Catalogue of the Greological collection founded in the Isthmus by the Commission

C.

\section{STATISTICS.}

Table I. Notices of the towns and villages in the southern divison of the Isthmus with their population ..$\dot{C}^{\circ} \cdot{ }^{\circ} \cdot$

" 2 Notice of the principal Haciendas and Ranchos of the southern division with their number of cattle . . . . 120

" 3 Towns and Villages of the Northern division, population and cattle . . . . . . . . . . . . .

" 4 Haciendas and Ranchoes of the northern divisionpopulation and cattle . . . . . . . . . 122

" 5 Summary of Inhabitants and cattle . . . . . . . . 123

D.

Table of distances to the principal ports in the Pacific and Indian Oceans, compared with voyages to the same, via the Isthmus of Tehuantepec

E.

Table of various canals in the United States-Canada-France-

Holland-and Great Britain . . . . . . . . . . 128 


\section{PREFACE.}

IN presenting this account of the Isthmus of Tehuantepec to the Public, the Editors deem it necessary to premise that it has been principally compiled from two reports published in London, in the year 1844, by Sr. Gaetano Moro, the Engineer, under whose superintendence the Survey was executed; and it has been their endeavour, in all statements of facts, to give them as near as possible, in the words of Sr. Moro, as found in his publications.

They have, however, thought it advisable to re-arrangc the materials in their present order, differing in this respect from the work of Sr. Moro. They have omitted such parts as purely described the scientific methods adopted by the engineers, but the results are carefully preserved in the Appendix, in a tabular form, as given by themselves.

The Comparison of the various proposed lines of Communication across the American Isthmus has been stated, with some additions, not given by Sr. Moro, but which are rendered necessary in consequence of a Report by M. Garella, on the Isthmus of Panama, having appeared in the Journal des Debats in Paris, on the 15th January, 1846, while this work was still in the press.

The chapter of Estimates of Returns did not appear in Sr. Moro's first work. The materials he collected in his additional Report have, however, been made use of by the present Editors, with some modifications. 
A Comparative Table of Distances which would result from opening a Ship Canal across the Isthmus of Tehuantepec, proving at one view the palpable advantages of such an enterprise being accomplished, is now given for the first time; as also a Table of various Canals in different countries, shewing that the proposed Canal of 'Tehuantepec differs in no extraordinary degree in any of its dimensions of length, depth, breadth, lockage, or summit level to be crossed, from similar works already executed in Great Britain, France, Holland, or the United States-these will be found in the Appendix, such additional information being deemed useful to the public for forming a correct estimate of all the bearings of the present Project now submitted to its judgment for approval. 


\section{IN'TRODUC'ION.}

ON inspecting the map of the American isthmus, the idea naturally suggests itself that the narrowest portions of it are those which would probably offer the greatest facilities for the opening of a communication from the Atlantic to the Pacific Ocean, and from this circumstance they have always attracted a greater share of attention. Repeated surveys having, however, proved that under these deceptive appearances were concealed difficulties almost insurmountable, the public mind has, at last, become accustomed to consider the enterprise as one of the most gigantic.

The recent survey of the isthinus of Tehuantepec, executed under the direction of the engineer Sr. Gaetano Moro, has proved beyond all doubt, the fallacy of this opinion. He was well aware, notwithstanding, that a deeply rooted prejudice is not easily eradicated, and he felt the more anxious, when the truth of the practicability of the work presented itself forcibly to his mind, after the most careful and oft repeated observations, to impart to others the intimate conviction which he felt upon the subject; and in this spirit he penned his Reports which were published in 1844. His efforts have not been altogether fruitless-public feeling in favour of a work, anxiously looked for during three centuries, has been once more revived by the prospect of increased facilities for its attainment-men of science and practical knowledge in various countries, both of the Old and the New world, have given their careful attention to the subject, and freely expressed their unqualified assent to his views through the medium of the public press - and the probabilities of success no longer rest on his bare assertion, unsupported by 
the testimony of high authority. It has been seen that the work proposed, far from exceeding the ordinary means of attainment, falls considerably short of such as are the object of daily enterprise, so much so indeed, that it is not even beyond the reach of individual exertion. The outlay of a comparatively insignificant sum would be sufficient to meet the first expenses and establish in the Isthmus a temporary line of transit. The produce of the country would subsequently furnish the necessary means, to complete the work in a few years.

But this would entail a delay to which it is more than probable there will be no necessity to submit. Works, which though of great magnitude are of undoubted and acknowledged public utility, fail only to be undertaken whilst there exists a doubt of their practicability; the latter once established the execution must follow, sooner or later, in the natural and infallible order of things. The opening of the Isthmus of Tehuantepec is in the number of such undertakings; the question, therefore, is not whether the work can and will be accomplished, but who shall undertake it; and under these circumstances, it should be borne in mind that the nation whose subjects shall have more immediately contributed to the accomplishment of this great work will naturally acquire in the Isthmus the largest share of its advantages.

It is, therefore, with a view to incite our countrymen to the undertaking of so great and important an enterprize that the present account of the Isthmus of Tehuantepec is now placed before them, in the firm conviction that the statements therein contained merit every confidence, and which, when more generally known, will be fully appreciated, and receive the patronage of an enlightened and discerning Public. 


\section{CHAPTER I.}

Advantages of an Oceanic Communication, through the American Isthmus; and Preference which ought to be given to the Territory of Tehuantepec over those of Panama and Nicaragua.

The project of a communication between the Atlantic and Pacific Oceans, has been the object of scientific investigation ever since the discovery of America, and had always attracted the attention of the Spanish Government during the period that a great portion of that country formed an integral part of the monarchy.

Christopher Columbus was the first to estimate the great importance to the whole world of a maritime communication, across the American Isthmus. The advantages that would result from it are indeed so evident, and the lucid observations of Humboldt, are so well known and appreciated, that it appears to be needless to repeat them in this place; we will therefore only add a few other remarks which will give them a more extensive application.

It is generally acknowledged that if the communication be once effected, all the vessels which from their ultimate destination are now compelled to double Cape Horn, would, of course, pursue their route through the Isthmus. It is also admitted, that in consequence of the favourable winds and currents, this voyage would be preferred to that round the Cape of Good Hope, even for vessels proceeding from Europe to China and Japan; but it is believed that it would be by no means equally convenient for their return from China to Europe, still less for the voyages to and from the East Indies. 
If, in order to solve this problem, we were to consider only the positive distance that separates the extreme points of these navigations, only about 1000 miles would be gained in the latter case by following the course through the Isthmus in preference to that at present adopted round the Cape of Good Hope; but if, on the one hand, we take into consideration the difficulties and dangers to be encountered in this navigation, and on the other the advantages which might be derived from making a halt half way, in a country undoubtedly destined by its natural wealth to the highest future prosperity, as well as the additional and incalculable advantage of being enabled to estimate beforehand the probable length of the voyage, it cannot be doubted for an instant that the course through the Isthmus ought at all times to be preferred. 'This opinion, which may now appear doubtful, will certainly cease to be so on that day, probably not far distant, when the progress of mechanical science will enable the mariner to disregard altogather the uncertainty of the wind, and when that route will be deemed the best which offers the safest navigation.

The American isthmus extends from the Gulf of Darien, where it is united to South America, as far as Tehuantepec, where North America may be said to commence. Different parts of this isthmus have appeared to offer advantages in their topographical form, and have invited attention to their fitness for the desired communication. It was however soon observed that only three of these localities were worthy of consideration; namely, those which from the principal towns in their territory are designated by way of distinction, isthmus of Panama, of Nicaragua, and of Tehuantepec.

In respect to the first of these named places the distance between the two oceans is only 41 miles. It is impossible therefore to examine the map of the American isthmus without being inclined to consider this point as the most eligible. The distance that divides the two seas is greater at Nicaragua, namely 93 miles, but being intersected by a lake of vast dimensions, this point would also appear to offer considerable advantages. Lastly, the territory of Tehuantepec, forming a continued line of 136 miles is that which upon a superficial exami- 
nation seerns to present the greatest obstacles for the accomplishment of the object contemplated.

However, notwithstanding these appearances, as a greater or less distance is not the only circumstance to be considered, it precisely happens in the three above-mentioned instances that the practicability of the work is in an inverse ratio to the shortness of the distance; and thus, whilst in the present state of our knowledge its execution is apparently impossible at Panama, and attended with immense difficulties at Nicaragua, we find it practicable and easy at Tehuantepec.

The isthmus of Panama has been from the time of the conquest the object of the most diligent irivestigations, and it is an error to suppose that the Spanish Government never paid any attention to this subject. Unfortunately not one of the explorations which were made offered any satisfactory result, and the silence relative to this subject, which was maintained by the celebrated astronomers who at the close of the last century resided for some time in these regions, is the greatest proof that they had no favourable tidings to communicate to the world upon this important matter.

The form and topographical aspect of a country so limited in extent, and which had attracted a considerable share of public attention, could not possibly remain unknown during three centuries, and it was very evident that there were not in either of the two opposite coasts any natural harbours to which the extremities of a canal could be directed. 1t has been lately asserted that all difficulties had disappeared, and that it would be as easy to construct a canal in Panama as it would be in Holland. The most recent report, however, of intelligent engineers purposely sent thither to ascertain the facts seems on the contrary to point out the great obstacles which the territory presents to an enterprise of this nature; but even supposing that the topographical aspect of the ground offered no difficulty whatever, there are others quite sufficient to render it impracticable, and which unfortunately cannot be remedied.

Monsieur Michel Chevalier, while examining the circumstances which ought to be kept in view in selecting the most 
appropriate place for an oceanic communication, very justly observes that one of the most important is its salubrity. $\mathrm{He}$ says :

"However great might be the saving of time effected by " steering through the Isthmus, it would always be shunned by "vessels if it were to prove a charnel-house."

The climate of the isthmus of Panama is acknowledged to be dangerous, a fact confirmed by the accounts of Humboldt and other writers. The fear of its unhealthiness was one of the causes that prevented the assembling of a Congress there, after the emancipation of the States of Spanish America, in order to establish a system of general policy suited to the interests of the American nations. The same fear prevented the engineers, Lloyd and Falmarc, remaining in the Isthmus a sufficient time to complete the labours of the exploration, which they undertook in 1827 and 1828 by order of General Bolivar. To this grievous cause is likewise to be ascribed the paucity of population and the want of the necessary means of existence in that isthmus.

The Isthmus of Panama has been lately explored by M. Garella, an Engineer appointed by the French Government, and, (whilst this work was still in the press) the results of his investigations have been given to the public in the Journal des Debats dated the 15th January this year, (1846).

The following are the most remarkable facts contained in that Report, and they decidedly confirm the opinions now geuerally entertained that the cutting of a Ship Canal is an impossibility across the Isthmus of Panama.

M. Garella first, gives his opinion that a Ship Canal across the American Isthmus at any of the points spoken of can alone satisfy the wants of Commerce and the just expectations of the civilized World; but if such a work cannot be accomplished, then he says distinctly that it would be money and pains thrown away to do anything more than to keep open a common well constructed road. A railroad would be quite preposterous over such an unhealthy country as the Isthmus of Panama. The only interests to be benefitted by such an 
arrangement might be respectively the mail and passenger steam boats on the Atlantic and the Pacific; but would not be of the least utililty to the general trade of the world.

A railroad would at first sight appear to offer facilities for the transit of goods across the 1sthmus, but it at once involves the necessity of every cargo requiring two vessels before it could be delivered at its port of destination, one for the Pacific, the other for the Atlantic. Next, even were that thought no difficulty, these two vessels must be so exactly timed as to be on the respective sides of. the Isthmus on the same day and that would be out of the question to consine for China or New Zealand voyages; nor could such a railway be of the slightest use to the vessels destined for the Fisheries and other traffic over the immense Pacific ocean. Warehouse-room for goods would have to be provided for an indefinite time on both sides the Isthmus; passengers would run the risk of fever during this delay; and although it may be said the mail boat steamers might almost calculate to an hour their respective arrivals yet even this only takes place once in the month, and how is such a limited traffic to pay the cost of maintaining the railway the whole year round? and what is to be the fate of all the officers and workmen who must remain at their posts every day in the year in the deadly marshes of Panama?

Even for the full security of passengers, mails, and treasure, costly harbours must be formed on both coasts which will greatly add to the extravagant expenses; so that with all these accumulations of charges, difficulties, and dangers, with the tolls of transit, and duties to the government superadded, there would be less expense and risk after all by the old route of Cape Horn! therefore Mr. Garella is quite right in asserting that the present mode of transit across the Isthmns of Panama by mules and horses, or perhaps common carriages on a macadam-

- ized road, is all that can be done even for the sole advantage of the mail steam-boats that visit this Istbmus 12 times in the year.

Mr. Garella next proceeds to investigate the possibility of forming a Ship Canal across the Isthmus of Panama, and without detailing all his plans and calculations, we extract the fol- 
lowing to shew what difficulties such a project has to encounter.

Having examined all the passes, he made choice of the route commencing at the little Bay of Vaca de Monte 20 Kilometres (12 miles) west of Panama, he makes it 543 Kilometres (34 miles) to the river Chagres; passing over the gap of Ahogayegua 140 metres (or 460 feet) above the sea level; and continuing $9 \frac{1}{4}$ Kilometres ( $5 \frac{3}{4}$ miles) in the bed of the Chagres as far as Gatun, he then goes direct to the Bay of Limon a distance of $12 \frac{1}{2}$ Kilometres ( $7 \frac{3}{4}$ miles) being a total of 76 Kilometres ( $47 \frac{1}{2}$ miles) from sea to sea.

Mr. Garella admits the impossibility of any supply of water being conveyed to the summit level of the gap of Ahogayegua though it be no more than 140 metres ( 460 feet) high. The greatest height to which water could be conveyed by trenches is 41 metres (131 feet).

This suggests the necessity of adopting one or other of the following plans. Either to make an open cutting at the gap of Ahogayegua to the level to which water can be conducted which would require locks for every 3 metres of height-there would be on one side lockage for 48 metres, and on the other 54 metres, on account of the difference of tides in the two oceans. Or to pierce a tunnel at the same elevation, of dimensions sufficient to let ships of 1200 tons burthen pass through with their lower masts standing! of these two projects Mr. Garella inclines to the latter if the public could at all be led to contemplate the possibility of its execution. $\Lambda$ nd these are the dimensions he deems sufficient for the object.

Height from the bottom of Canal to crown of the Arch 37 metres (122 feet.) Breadth . . . . . . 21 " ( 69 feet.) Total length 5350 metres or 5900 yards.

This would further require approaches of open cuttings 45 to 50 metres deep (165 feet).

This tunnel M. Garella thinks would be cut through a solid rock of porphyry therefore probably not exposed to the chance of falling in and possibly requiring little or no masonry. However, allowing that this last might cost 14 millions of 
francs $(£ 560,000)$, he calculates the total expense of such a tunnel at about 50 millions of francs, or $£ 2,000,000$.

The two trenches required as water conduits would be of 62 and 37 Kilom. that is $38 \frac{1}{2}$ and 23 miles long, and it is further thought that reservoirs might be formed in the gorges of the neighbouring hills at small expense.

The cost of constructing harbours at Vaca de Monte, and the Bay of Limon enter into Mr. Garella's calculations for the sum of 12 millions, or $£ 480,000$.

Mr. Garella makes the grand total for the canal, tunnel, conduits, and ports, amount to the sum of 139 millions of francs, or $£ 5,560,000$.

Upon this statement we have the following observations to make :

First, Mr. Garella abandons at once the first project of an open cutting as an impossibility, from the vastness of the dimensions to be excavated, which would be of three times the size of the tunnel, even supposing it to admit of being perpendicularly wall-sided.

Secondly, Supposing a tunnel could be cut as stated, all vessels would have to strip their masts and rigging at the port of arrival, and replace them at the port of departure, operations of great difficulty and delay in any place, and dreadful risk of the lives of the crews in such a pestiferous climate as Panama.

Thirdly, The breadth of the proposed tunnel and lockage attached to it would only accommodate one vessel at a time, and sufficient breadth of towing-path is not allowed for; light and ventilation are not alluded to.

Fourthly, The dimensions given by Mr. Garella make the excavation about eight times that of the Box tunnel on the Great Western Railway; and the solid contents of 4,156,950 Cubic Metres, is calculated to cost only 12 francs each Cubic metre. Now we happen to know by long experience of mining operations within the tropics, that in cutting through such a porphyry rock as Mr. Garella describes, each Cubic metre would cost at the lowest estimate 60 francs, or 5 times more than Mr. Garella's estimate that is nearly 250 mil-

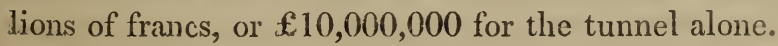


Fifthly, The calculation of Mr. Garella takes no account of the time required for the execution of the work ; the expense of conveying European Artizans to the spot, and the heavy salaries they must receive to compensate the risk of life they run at Panama; nor the cost of transnission of funds to pay the expenses; nor the weight of a heavy administration to superintend the works.

It may therefore be taken for proved from Mr. Garella's report ; first, that a railroad over any one of the proposed communications across the American Isthmus would be profitless to all the world, even to the Atlantic and Pacific Mail Packet Companies; and secondly that the cutting a Ship Canal across the Isthmus of Panama is not only beyond the resources of nations such as England, France, or the United States, but it may be said to be almost an impossibility.

The isthmus of Nicaragua possesses a fertile territory, a healthy climate, and is not deficient in population. Towards the north, the lake of Nicaragua communicates with the Atlantic by means of the river St. John, and to the south, only a small distance separates this lake from the shore of the Pacific. Thus the isthmus of Nicaragua seems to offer many advantages; but upon a more minute examination there appear many difficulties, and these of an almost insurmountable nature.

From the report published by command of the government of the state of Nicaragua in reference to the exploration of that isthmus, effected during the years 1837 and 1838 by Mr. J. Bailey, it seems that the course of the river St. John with all its windings is about 93 miles in length, six and a half of which are obstructed by four rapids, caused by ledges of rocks stretching across the whole width of the river. These obstacles, and the long course of the river were considered suçh formidable impediments as to suggest the construction of a canal as an easier operation than that of rendering the river itself navigable.

Towards the south, a distance of nearly 17 miles between the lake and the Pacific, the territory is occupied by a chain of mountains which, although not very elevated, would occa- 
sion works of extraordinary magnitude. It would be necessary to excavate a considerable portion of it to a depth much greater than has been hitherto customary in works of this kind and throughout more than $3 \frac{1}{4}$ miles it would be indispensable to bore the mountains, and open a tunnel of sufficient dimensions to admit the large vessels employed in transatlantic navigation. The impossibility of attaining such an object we have already shewn above, in speaking of the proposed tunnel at $\mathrm{Pa}$ nama, especially if the nucleus of the chain to be pierced through consists, as well as the Andes of which it forms a part, of granite or ancient porphyry, as there is every reason to believe notwithstanding the superficial experiments made by Bailey.

On the side of the Atlantic the port of San Juan de Nicaragua, into which the river San Juan empties itself uver a bar with only 3 feet water upon it, now only affords anchorage for a few vessels drawing 10 feet water; and could not be formed into a harbour for large ships except at an enormous expense.

The port of St. John south, which would be reached on the Pacific side, is not adequate from its very small dimensions to the required object, and moreover it appears that with the prevailing north and north-east winds its access is not only difificult but even dangerous.

In the isthmus of Tehuantepec, the greater part of the distance which separates the two seas is occupied on the south by lagoons and extensive plains, and on the north it is traversed by the river Coatzacoalcos; so that the principal works to be executed would be comprised within a space of about 50 miles in length.

The present project is the formation of a Ship Canal calculated for the passage of vessels drawing 20 feet water; it will have excellent ports at its extremities; and the materials for construction cannot be more abundant, superior in quality, or better distributed. A climate remarkable for its salubrity favours also the isthmus of Tehuantepec, and the departmients of which it forms a part, number a population of seven hundred and fifty thousand inhabitants.

The admirable fertility of the soil, and the abundance of cattle and resources of all descriptions would enable the vessels 
to renew their provisions at easy prices at the Isthmus, therefore they might devote a greater portion of their hold to the storing of merchandise.

Besides these purely local advantages, the isthmus of Tehuantepec offers over those of Nicaragua and Panama others of a more general nature for navigation, affording to vessels proceeding to Asia or the N.W. coast of America, a communication more direct and through a more genial climate. On their return, they are now obliged to keep in northern latitudes, and direct their course towards the Californias, in order to escape the influence of the trade-winds, and for these also the route through the isthmus of Tehuantepec would be much less circuitous. Lastly, the fresh but not dangerous north and northeasterly winds are common to the whole of the American isthmus, but Tehuantepec is not subject to the protracted calms which at some seasons of the year paralyse navigation at Panama.

The table $\mathrm{D}$ in the Appendix, shews a comparison of the distances of the voyages to the principal places in the Pacific and Indian Oceans affected by the opening of the proposed Tehuantepec Ship Canal, the immediate advantages of which to * Navigation are palpable without further demonstration. 
CHAP. 11 .

The Isthmus of Tehuantepec had been decreed to be oponed by the Spanish Cortes.-Proposals of Don José de Garay to the Mexican Government:-terms of the Grants made to him.-Scientific Commission of Survey appointed by Don José de Garay.-Departure of the Commission from Mexico.-Confidence due to the Reports of the Commission.

The Spanish Cortes, having in view all that had been written upon this subject, and the various reports presented by persons charged with the surveys of the principal points suggested for the communication, by a decree of the 30th April 1814, authorised the opening of a canal across the isthmus of Tehuantepec in preference to those of Nicaragua and Panama.

Since the declaration of the Independence of Mexico, no doubt from the distraction of political contests engrossing all other thoughts, the Government has been unable, until very lately, to turn its attention to the realization of this grand enterprize.

However, in the year 1842, propositions were submitted to the Mexican Government by Don Joseph de Garay for the opening of a communication over this Isthmus. (Appendix No. I.)

These propositions were declared to be accepted, by a decree of the first of March of the same year, and on the following day an edict was published, proclaiming that on such communication being effected, the transit should be open to all nations not at war with Mexico.

This decree concedes to Mr. Garay the exclusive privilege of executing the work; and as a remuneration grants him the establishment of the means of transport, with the right of tolls 
for fifty years; and the proprietorship of the waste lands, comprising a breadth of ten leagues on either side of the line of communication. It further authorizes, with ample privileges, the settling of colonies within fifty leagues on both sides of the line; and concedes the exclusive employment of steam locomotive power within the Isthmus for the period of sixty years: adding also in the same, as well as subsequent decrees, many other concessions of importance. (See Appendix, No. II. and III.)

Mr. Garay, being bound, at his expense, to make all the surveys necessary for the execution of the work, named the following scientific Commission for that purpose, viz:-

Director.

Signor Gaetano Moro.

Engineers.

Lieutenant-Colonel De La Troupliniere.

Captain Gonzalez, of the Staff Corps.

Secretary and Treasurer.

Don Pedro Garay, First Officer of the Ministry of War.

Assistant.

Don Mauro Guido, Lieutenant of the Navy.

This Commission set out for Tehuantepec on the 30th April, of the same year amply provided with every thing requisite; and as the following Memoir is compiled from the reports already presented to the Public in the past year by Sr. Moro, this chapter cannot more appropriately be concluded than by inserting verbatim the last few seritences from his work.

" I may perhaps be allowed, in presenting this Report, to ex" press my ardent wishes that our labours in the isthmus may " not be considered in reference only to whatever scientific me" rit they may possess, but as the means by which a most im" portant fact has been ascertained, and which I have described " with the strictest conscientiousness. Should it be so, I am " not without hopes that the great work which has been dur" ing three centurits so anxiously desired, and which the 
" present commercial and political state of the world loudly

" demands, will at length be undertaken.

"Many circumstances concur at the present moment high" ly conducive to its execution, and which ought to be made " available.

"The zealous interest which the Mexican Government " has taken in the matter is clearly demonstrated by the libe" ral concession made to the Projector, and by the promptness " with which all his applications have been favourably answer" ed, as may be seen by comparing their dates with those of

" the corresponding decrees inserted in the following Appen"dix.

"The Government of Mexico had undertaken to afford " every protection and assistance in its power to the enter" prise of Don José de Garay, and all the orders issued with " this view were punctually fulfilled. The Commission owe " their most sincere acknowledgments to the local authorities " of the isthmus. All the public officers vied with each other " in affording every possible assistance to the Commission; " forwarding their object by means of circulars and orders to " the inferior authorities, and readily furnishing all the infor" mation and particulars concerning their object which might " be useful and interesting.

"The inhabitants of that territory evinced the greatest de" sire for the realization of this great undertaking, and the "Commissioners were never compelled to make use of the " armed force which had been placed at their disposal. This "favourable disposition was never so apparent as during the " act by which Don José de Garay was legally put in posses" sion by order of the Government of the territories granted to " him, since besides its having been effected with the greatest " order, the proprietors of the adjacent lands who were present " declared before the civil and judicial authorities, that they " had no objections whatever to offer to the concessions, as " they did not at all affect their property.

"The Commission, fully impressed with the importance of " their mission, did not wish to assert any thing on mere con"jecture, nor to be guided by report which so frequently 
"proves erroneous. They would not, in fact, venture a single " assertion beyond what they could affirm to have seen and " investigated by their own observations. In so doing they " acted in accordance with the wishes of the projector, Don "Joseph de Garay, who conceived the undertaking with the " grandeur it deserved, nor would they otherwise have accept" ted the trust with which they were honoured. "The public, to whom this report is addressed, may there" fore trust the correctness and fidelity of the assertions which " it contains, ascribing only to inefficiency whatever errors of "calculation may have been committed, but by no means to a "want of zeal and conscientious diligence on the part of the " Commissioners. 
CHAP. III.

Notices of different Authors, ancient and modern, who have spoken of the Isthmus of Tehuantepec.-Cortes.-Dampier.-Cramer.Humboldt._Robinson.-Tadeo de Ortiz.-Orbegozo._Balbi.

The first point to which the Commission directed its attention was the investigation of all the former data upon the subject of the Isthmus of Tehuantepec.

I.

With the great Hernando Cortes originated the idea of a communication by this isthmus between the two oceans. Its topographical advantages evidently did not escape the perspicacity of that extraordinary man; for it cannot be explained why, in the midst of a country in general so prodigiously fertile, he should have chosen for his own domain the only portion of it comparatively unproductive, unless he clearly saw that any mode of communication to be hereafter carried into effect must necessarily be executed over this ground.

It appears from many passages in his celebrated letters to the Emperor Charles V., to have been an object of intense interest with Cortes to discover some strait which might naturally unite the two seas. In the outset he was encouraged by brilliant expectations, and he announced that he had already directed several vessels "to run along the Bay of As" cension in search of the strait, which it was supposed was to be there found."

In the meanwhile as his hopes of finding a strait were waning, the isthmus of Tehuantepec necessarily acquired greater and new importance in the eyes of Cortes. And it was he who 
conceived the idea of a lucrative speculation by means of a road over the Isthmus, to supply Spain with the spices of the East Indies and the products of such new regions as he expected to discover.

\section{II.}

Towards the end of the seventeenth century Dampier, speaking of the Coatzacoalcos, said-"This is one of the prin" cipal rivers of this coast; it is not half the breadth of the "Tabasco river, but deeper. Its bar is less dangerous than " any on this coast, there being fourteen feet of water, and but "little sea: within the bar there is much greater depth, and " a bed of soft oasie ground." * * * * "This river hath "its rise near the South Sea, and is navigable a great way " into land, especially with boats or small craft."

\section{III.}

The oldest amongst the documents of greatest importance which have been obtained, is the narrative of a royage of discovery which the engineer, Don Augustin Cramer, governor of the castle of San Juan de Ulua, performed in 1774, by order of the Viceroy, Don Antonio Maria Bucareli. His report, although so brief as scarcely to occupy one sheet of paper, is nevertheless a proof of sound judgment, and of the professional views of a man of great capacity.

After his arrival at the isthmus, by the gulf of Mexico, he commences with this important notice:- "The bar of the " river Coatzacoalcos has on it at half-tide, 24 palms of water, " excepting a very small portion of its length, on which there " are only 18 palms."

"These soundings correspond with those taken on the first " survey, and afterwards by me; for which reason, and as fre" quent soundings taken by the present pilots during the last " thirteen years agree with them, it may be inferred, that the " said bar is permanently in the same state, or that if any " variation occurs, it is so inconsiderable that it has escaped " notice."

"After passing the bar, the river is six to eight fathoms "deep." 
Cramer continues his narrative briefly describing, but with admirable exactness, the course of the river up to Mal Paso, and demonstrates the facilities which the country presents for making a good road from this point to Tehuantepec, concluding with the remarkable observations here literally transcribed.

" The river-courses, with the mountain-chain interrupted "between Santa Maria Petapa and San Miguel Chimalapa, " and the evenness of the grounds, plainly indicate that it "would not be a work of great difficulty, nor excessively " costly, to effect a communication between the two seas " across this isthmus. In the supposition that the waters of " the rivers Almoloya and Citune were held back, a canal " might be opened to join them with those of the San Miguel " or Chicapa, the course of which into the Pacific Ocean, by " the bar of San Francisco, passes by the Venta de Chicapa, " and from this spot forwards there are no further difficulties, " because it is one perfect plain as far as Tehuantepec."

An examination of the topography of the isthmus, will shew how rational was this project, bearing in mind its application to a canal of small dimensions, such as was contemplated by Cramer.

\section{IV.}

It was with reference to these results that Baron de Humboldt, after having very properly asserted that until his time " the topography of the isthmus of Tehuantepec was quite " unknown in Europe," adds, "we cannot doubt that this "point of the globe deserves no less attention than the lake "of Nicaragua." However, it is evident that if the illustrious traveller ever saw any of the writings of Cramer upon the subject, it could not be the one just mentioned, for there is no allusion in it to the possibility alleged by the Baron, of a canal "without locks, or without inclined plane."

\section{V.}

In 18\%0 Robinson, speaking of the Coatzacoalcos, says, " it is the only port in the Mexican Gulf where vessels of war, 
" and others of a large size, can enter, and is far superior ei" ther to Pensacola or Espiritu Santo. There are at all sea" sons on the bar, at the mouth of that port, twenty-two feet "water."

\section{VI.}

When the Mexicans had established the independence of their country, their first natural desire was to promote the development of the various elements of prosperity which their territory possesses.

In the year 1824, the state of Vera Cruz and the Federal Government, appointed each a commission to survey the isthmus: the former chose Don Tadeo de Ortiz, and the latter selected Colonel Don Juan de Orbegozo of the general staff; but it was only after the return of our commission to Mexico, that the reports of Senor Ortiz could be obtained.

His attention was especially directed to the promotion of colonization, and the cultivation of these fertile and favoured districts of the republic, upon all of which topics he enlarges with much enthusiam; but on what relates to our purpose he furnishes no light whatever, and his plans are not admissible, excepting only in so far as they propose to render the Coatzacoalcos navigable to the confluence of the Malatengo. He also observed the facility with which the Boca Barra of San Francisco might be opened for the admission of large ships.

In the sequel we shall advert to these observations, but limit ourselves at present to quoting those which refer to the bar of the Coatzacoalcos, and which are very important.

"The bar of the Coatzacoalcos is permanent and constant, "forming two canals or channels; that to the left or the " west, has on it in the rainy season (that is, from the begin" ning of June to the end of February) $3 \frac{1}{2}$ fathoms of wa"ter, or 21 feet, these being increased to 23 at high tides. "That on the right or to the east, has $2 \frac{1}{2}$ fathoms, or 15 feet, " and both during the dry season lessen three or four feet, the " principal channel maintaining itself at not less than 18 feet, " except perhaps under extraordinary circumstances. When " a vessel would effect an entrance, with a view only to grea" ter security, the 15 feet channel should be preferred, because 
" it has less current in it, and is probably wider, and because "when the sea-breeze blows hard, the currents are rapid in " the great channel setting from east to west, and without ta" king a pilot it would be difficult if not dangerous to be en" tered by vessels of great draft of water."

"Since the direction of the channels is from north to south, "we are of opinion that vessels can enter with the wind from " north, north-east and the easterly and southerly monsoons, by " keeping to the wind. The prevailing winds offer no difficulty "with the same precaution, only attending to the currents, "which, as before said, run with rapidity from the east to the "west, and might cause vessels to be stranded. However, " there are probably some periodical variations to the pheno" mena, which mariners would be the most competent to ap"preciate for their guidance."

"The departure of vessels by both channels cannot of course " take place with the above winds, but easily with those from " the south and west, and off the land. The latter of which " almost every day prevails, at least during the rainy season, " from after midnight till eight or nine in the morning, when " the sea-breezes commence; on which account vessels should " proceed to sea after five o'clock A.M., until seven, but not " later than eight, which is allowing sufficient time for vessels " to be beyond the danger of drifting into the dangerous iron"bound bay which is formed by the ridge of San Martin, run" ning out to a promontory."

It is evident that all these difficulties, described by Señor Ortiz for the entrance and exit of vessels, will completely disappear by stationing steamers at the mouth of the harbour.

\section{VII.}

The survey of Senor Orbegozo was made contemporaneously with that of Senor Ortiz, but he admits that he was in want of many things, and that on this account the results of his rapid examination must be defective under the unfavourable circumstances in which he was placed.

The report of Senor Orbegozo commences like that of Senor Cramer with a description of the course of the Coatza- 
coalcos; and he states that it has 14 feet water upon its bar; but it is to be observed that probably he did not enter by the deepest channel. Besides, it was the month of May, the ordinary dry season, which had succeeded a year of notable scarcity of rain.

Senor Orbegozo found, as well as Senor Ortiz, that it would be both easy and advantageous to render the Coatzacoalcos navigable as far as the confluence with the Alaman (or Malatengo); and from this point he proposes a carriage-road to be made as far as the lagoons, passing by the Chivela instead of by the Portillo de Tarifa, as proposed by Ortiz.

"Possibly," he say, "it might not be very expensive to " excavate a haven on the opposite side of the bar of Santa "Teresa, for vessels drawing 20 and more feet of water, and " also to deepen the principal bar."

\section{VIII.}

We must not conclude this enumeration of the data which have been collected relative to the topography of the isthmus of Tehuantepec, without quoting the opinion of the first geographer of our times, the judicious Balbi, who considers the Coatzacoalcos "as the finest port of all the rivers which " discharge themselves into the Gulf of Mexico, not even ex" cepting the Mississipi itself." 


\section{CHAP. IV.}

Proceeding of the Commission of Survey at the Isthmus.-Measurement of a base line on the beach between St. Mateo and Santa Maria.Examination of the district of Tehuantepec.-Las Ventozas and near the Morro unfit for anchorages. - Trigonometrical observations at San Dionisio, Camotepec, Juchitan.-Examination of the upper and lower Lagoons-The Boca Barra.-The River Ostuta.-Its waters to feed the Proposed Canal.-The ground north of the Chivela, Guichicovi, Boca de Monte.-First view of the Coatzacoalcos at Mal Paso, its Transparency, firm clay bants, slow current, its borders lined with thick woods.-Excursion down its Course to its Mouth,Weather then unfavourable for Observations.-Visit to Acayucam, -The Jumuapa.-Return to Tarifa.-Venta de Chicapa.-Ground examined from San Miguel to the Rio del Corte (the upper Coatzacoalcos.-Cerro de Albricias, the view from this fixes the choice for the passage of the Canal over the Gap of Tarifa. - Its minute description.-Departure of Captains Robles and Gonzalez to survey the Coatzacoalcos.-The River Chicapa.-Tarifa and the Ultimo Rancho have the same level,-Volume of the waters of the Chicapa below its junction with the Monetza.-Cerro del Convento,-Source of the Monetza and the river at Tarifa, same level; also the Portillo.-The Ostuta examined and practicability of joining its waters by a Conduit to those of the Chicapa.-Captain Robles completes the Survey of the lower Coatzacoalcos, and examines its upperwaters down to the Sarabia.-Sr. Moro explores the ground from Tarifa to the confluence of the Malatengo with the Coatzacoalcos;-also from Tarifa to the Rio del Corte.-Re-inspection of the proposed line of conduits for the waters of the Ostuta and Chicapa to Tarifa by Messrs. Moro and Robles, and their confirmation of its practicability-Final Return of the Commission to Tehuantepec the exploration of the Isthmus being completed.

The Commission arrived at Tehuantepec on the 28th. May, 
and the preliminary arrangements occupied it until the 2nd of June.

The possibility of effecting a communication between the two oceans through the Isthmus may be considered under four different aspects.

1. By a road.

2. By a canal for barges only.

3. By these two means combined.

4. By a canal of great dimensions, which would afford a transit to the loaded vessels themselves from sea to sea. It is natural to suppose, that this plan being by far the most advantageous was that to which attention was chiefly directed.

All accounts agree in the facility with which the river Coatzacoalcos might be rendered navigable, at least so far as its confluence with the Sarabia; therefore the space which it was most important for the Commission to explore was that intervening between this confluence and the shores of the Pacific.

The rains appeared to have set in on the mountains (Sierra), which prevented the possibility of exploring them, and as time was limited, it was resolved to take advantage of it by commencing proceedings on the southern side of the Isthmus.

With this view a rapid excursion on the coast was made, and the ground that divides the villages of San Mateo and Santa Maria, appeared well calculated for the measurement of a line to be used as the basis of the trigonometrical operations; and consequently the exploring party established their residence at San Mateo.

Messrs. Ortiz and Orbegozo had discontinued the soundings of the lakes and the Boca Barra (bar entrance) of St. Francisco, because they could not find a boat for the purpose. This want was at once provided for by adapting a sail, oars, and helm to a common canoe.

Landmarks were erected in those places which appeared the most fit as vertexes of the primary triangles. The ground for a base line was finally selected on the beach, which happening to be remarkably level, was admirably adapted for the purpose.

The tracing of the base was an operation attended with immense difficulty. The rainy season had commenced and fre- 
quently impeded the prosecution of the survey. An almost incessant wind either blew down or inclined obliquely the landmarks, or causing the instruments to oscillate violently, disturbed the observations; and lastly, with the exception of a few moments before the rising of the sun and after its setting, a dense flickering vapour hid from view the objects which served as guides, whilst the refractions, especially the lateral ones, produced the most strange illusions.

The Zapoteco soldiers, who carried the chains, evinced a wonderful degree of intelligence, and in a very short time they became as proficient as could be wished.

After the necessary corrections to the mean sums of the separate measurements, the total length of the base was obtained, showing an aggregate distance of 16,930 metres or $10 \frac{1}{2}$ miles.

The survey commenced at the villages of St. Mateo and Santa Maria, referring to the points trigonometrically fixed. The same was afterwards done with the coast of the Pacific as far as the Morro, and the tract of country between the sea and the town of Tehuantepec, including the course of the river by which it is watered, and which flows afterwards into the haven of Las Ventosas.

It has been suggested that this bay might be used for the purpose of anchorage; but, on examination, it was found that its small size, as well as its exposure to the prevailing,winds, made it totally unfit for such purpose, even supposing it were deep enough. The other haven to the west of the Morro is also too much exposed, and filled with dangerous reefs; and though it be true that Cortes launched a few vessels in the first of these coves, it is well known that in those times vessels were built of small dimensions; and probably he made use of that spot, not because he considered it fit and safe for such an operation, but simply because it was the only one near at hand where it could be at all accomplished. The sands carried down by the waters of the Tehuantepec are now fast accumulating in the bay, and before long it will be completely obstructed.

The Commission then procceded to San Dionisio Tepehuazontlan, and Sr. Moro carried on his observations in Camotepec and Juchitan, and proceeded to reconnoitre new points, in 
order to extend the triangulation. He then sailed from the quay of Salina, near the Estacada, in the canoe fitted out as before-mentioned, and passing between the islands of Monapostiac and Natar-tiac he arrived at San Dionisio, the sounding line constantly showing nearly six metres ( 20 feet) depth of water, the bottom being mud and shingle, both easy to remove.

It was supposed before this exploration that the lower lake extended as far as the bar of Tonala about 38 miles to the east of the Boca Barra leaving between the lake itself and the $\mathrm{Pa}$ cific a narrow strip of land, designated by the name of the island of St. Francisco. It was believed, also, that the whole of the lake was nothing else but a creek of little depth and of no importance, as is the western part of it, known likewise by the names of lagoon of Tilema, and Dead Sea. However, on ascending the hill of Umalalang, which overlooks the village of St. Dionisio, this erroneous impression was soon dispelled, by observing that the ground to the east of Boca Barra extends itself considerably, and contains other lakes of some extent.

On proceeding thither, the eastern part of the lower lagoon attracted Sr. Moro's attention, as he could not but observe that its vicinity to the Boca Barra and the canal of Santa Teresa, its considerable depth and excellent bed, and the circumstance of being so well sheltered from the prevailing winds, fitted it admirably for a commodious and safe anchorage.

Whilst Captain Robles, an officer of the Engineers, who had lately joined the Commission, was surveying a portion of this lake, S. . Moro proceeded with Lieutenant Guido to explore the Boca Barra. The tide, which was beginning to ebb, produced a current that did not allow them to steer their imperfect craft, and was carrying them towards the sea with such force, that they clearly saw by the effort necessary to keep their position, that it would be impossible to surmount its impetus so as to effect their return, should they be carried out. The tide was too strong to use the sounding line, but it was evident that a sand bank obstructs internally the Boca Barra throughout its whole length from east to west, and it appeared to be important to investigate the cause which might have produced it.

As the idea that a canal of great dimensions was the only 
advantageous means of effecting the desired communication every endeavour was made to ascertain the course and volume of the waters of the several rivers, without being deterred by their distance from the localities pointed out hitherto as the most favourable for the purpose. Amongst them all, particular attention was directed to the river Ostuta, remarkable for the volume and regular course of its waters, which were said to flow into the Pacific by the bar of Tonalá.

The origin of this river is unknown and has never been examined from the popular belief that it proceeds from a spot so rugged among the mountains as to be almost inaccessible.

In the course of the operations it was found that the river Ostuta does not discharge itself into the Ocean by the bar of Tonalá as had been supposed, but that after having formed the lagoons, situated in the neighbourhood of St. Francisco, it flows through the Barilla and the mouth of Lagartero, in the Duic-nahuanot.

It may be well to observe, that although the waters of the Chicapa and of the Ostuta are always limpid, this is only to be understood of the upper part of their course, for $n$ the plain during the rainy season they often gather the sands of the alluvious soils through which they flow.

On entering the eastern lower lagoon, the currents of the Ostuta flow along the southern shore, and decreasing gradually in their impetus they reach the Boca Barra so powerless as to deposit there the sands they bring with them; these are afterwards shaped into a large sand-bank by the waves, kept in incessant agitation by the northerly wind which prevails almost constantly in those regions.

In the plans which will be proposed, it is intended to make use of the waters of the Ostuta, taken from the sierra, in order to feed the canal, by doing which the principal cause of the formation of this bank would be removed; but as it would not be possible to prevent the waters that join the Ostuta in the plain from flowing in the same channel, and as this river did formerly flow into the lake of Tonalá, it would be advisable to shape again its course in the primitive direction, an operation which offers no difficulty whatever. 
The sand-bank of the Boca Barra, however, may be attributed to another and more powerful cause. The river Tehuantepec flowed not many years ago into the western lower lagoon, as may be seen by the map of the southern division of the isthmus. The opposing currents of both rivers destroyed reciprocally their strength, and caused the deposit in that particular spot of the matter they bring with them. Fortunately the river Tehuantepec spontaneously abandoned this direction, and care should be taken to preserve it in the course which it has now adopted.

Taking advantage of a calm, between two tides, Messrs. Robles and Guido succeeded in going out to sea through the Boca Barra, and executing the soundings indicated in the plans. They found that immediately after passing the bank there is a channel, the depth of which, even in the shallowest part, is of nearly $19 \frac{3}{4}$ feet, this depth increasing afterwards rapidly.

The exploring party concluded operations in this part of the isthmus, and returned shortly afterwards to San Dionisio.

The party assembled at Juchitan towards the end of October. This spot proving to be the centre of several trigonometrical operations had been selected for the purpose of referring to it the position of all the other points, after having previously ascertained its exact latitude and longitude.

'The season being now sufficiently advanced the exploring party was divided into two sections, one of which was entrusted to Captain Robles, in whose abilities complete reliance could be placed. This section established themselves in the Venta de Chicapa, which from that moment became the meeting point of the Commission until the close of their labours in the isthmus.

Mr. Moro and his party proceeded northward, passing through Chivela, Guichicovi, and Bosa de Monte. Guichicovi is situated at the commencement of the rugged part of the sierra; and the gentle hills in the neighbourhood of Chivela, approaching this spot, are, at intervals, interrupted by precipitous ravines, through which several rivers and streams find a passage for their waters. The surface of the ground becomes more level receding from Guichicovi towards Boca de 
Monte, from whence, as far as the Mal Paso, it finally becomes a perfect plain, occupied by a forest of useful and precious timber.

On arriving at the Mal Paso, they were surprised at the view presented by the Coatzacoalcos, which from the transparency and slow progress of its waters had more the appearance of an artificial canal than that of a mighty river. Its banks of strong clay, are firm and easy of access, with an almost uniform elevation of a few metres, which leads to the supposition that the river runs along a level surface, although the thick woods that line its shores conceal from view the topographical aspect of the land covered by them.

This excursion along the river scarcely deserves the name of an exploration, especially as the weather was so unfavourable as not to allow of making any kind of observation. Neither was it possible to take soundings of the bar on this occasion; but it was only a few years ago a French vessel drawing 18 feet water entered it; and from the battery situated at the left entrance its principal channel appeared more gentle and clear than any other with which Sr. Moro was acquainted. It is well known that bars owe their formation to the materials conveyed by rivers, hence the unobstructed regularity of the bar of the Coatzacoalcos is simply accounted for by the clearness and limpidity of its waters.

A short exploring expedition was made from the Fabrica or Mina-titlan, to Acayucam. After the return to Mina-titlan the Coatzacoalcos was again ascended as far as its confluence with the Jumuapa, and this was also ascended as far as the Paso de la Puerta. From this place the party took the direction of Chivela, passing by Guichicovi.

From Chivela, Sr. Moro proceded towards Tarifa along a table-land covered with a great number of gentle and interrupted declivities, and along a road so level, that it inspired him with the most flattering hopes. From Tarifa the ground continues to be still more favourable as far as the Portillo or gap, from which a rapid descent leads to the plain, in which is situated the Venta de Chicapa. This tour had lasted a month, during which Messrs. Robles and Gonzalez had actively coni- 
tinued their operations, not only in the lower part of the country, but also in that which extends from the village of San Miguel to the hills of Petapa. Captain Robles had likewise examined the ground from San Miguel to the river del Corte, in the neighbourhood of Santa Maria Chimalapa.

Sr. Moro now resolved to reconnoitre the points which had been fixed during his absence. On arriving at one of these, on the summit of a hill about one mile to the north of the village of San Miguel, which afterwards received in commemoration the name of Cerro de Albricias (Reward hill), Sr. Moro saw the problem at once solved.

The Sierra Madre (or principal chain of the Andes) appears to be interrupted, as the engineer Cramer judiciously observed, between Santa Maria Petapa and San Miguel Chimalapa. On the western side it descends rapidly as far as the first of these villages, and proceeds again suddenly towards the east of the second, leaving in the middle a surface comparatively level. To the south the small chain of Masahua and Espinosa, of moderate elevation, forms a barrier between this hilly tract of ground and the true plain, terminating at their extremities in two openings or gaps, through the westernmost of which descends the road from Chivela leading to the plain, and another through the eastern from Tarifa to the Venta de Chicapa. On the north, the table-land extends itself, gently descending as far as the Coatzacoalcos, and from thence to the Atlantic.

The river Chicapa reaches San Miguel, occupying in its course from east to west the bottom of a straight dale, between two uninterrupted chains of mountains, and then suddenly turns in a southerly direction towards the plain wherein is the upper lagoon which receives its waters.

Running in a line diametrically opposite to the first course of the Chicapa, namely, from west to east, the stream of Monetza joins the above river near San Miguel, by another dale, which in reality is only the continuation of the first, and would lead directly to Tarifa were it not divided from the plain on which this estate lies by a small chain, of which the Cerro del Convento forms a part.

The village of San Miguel is situated in a small valley, lower 
than the plain of Tarifa, by more than 264 feet; but as the most northern of the two chains between which the rivers Chicapa and Monetza are enclosed has no interruption whatever, Sr. Moro thought it possible to convey along its side the waters of the first of those two rivers as far as Tarifa, from whence they might be distributed to both seas; neither did he consider it difficult to surmount the natural barrier formed by the small chain of Converito, between the valley of the Monetza and the table-land of Tarifa. The hill of Convento rises almost isolated, and the gaps on both sides, especially the northern, is of so trifling an elevation above the ground, that a cut through the latter would be an almost insignificant undertaking.

This discovery induced Sr. Moro at once to give up the idea of his returning to the Coatzacoalcos with the view of surveying its course, and this operation was entrusted to Messrs. Robles and Gonzalez, who inmediately proceeded thither for the purpose.

Meanwhile Sr. Moro directed that Lieutenant Guido should station himself at Tarifa with a barometer, whilst he, following the dale of the Chicapa, took with him another to the place called the Ultimo Rancho.

Two series of barometrical observations performed simultaneously in two successive days, and under the most favourable atmospherical circumstances, showed that these two points are on the same level, whilst about $1 \frac{1}{4}$ miles higher up from the spot in which Sr. Moro stationed himself, the river forms a cascade of nearly 23 feet high.

From San Miguel to the Ultimo Rancho five constant streams join the Chicapa, and having measured the waters of this river in a point below its junction with these streams they were found equivalent to more than 5 metres or 176 cubic feet per second, so that by adding to it the Monetza, and the stream which runs through San Miguel, called Xoxocuta, a body of waters of about seven cubic metres or 247 cubic feet may be reckoned upon. According to all the information collected, these waters were then in a state which 
might be considered the minimum of their quantity, and they are always exceedingly clear and pure.

This satisfactory result induced Sr. Moro to undertake without loss of time the inspection of the hill of Convento, in order to judge of the magnitude of the difficulties that might offer in that quarter.

In that part where the hill of Convento is most depressed, namely, the northern side, the river Monetza takes its source, and following along a dale in the centre of the hill itself, penetrates under it, and crossing it entirely, comes out in the small valley in which it runs to San Miguel. The point of the opening in which the river has its origin is entirely hollow, since the gush of water which forms it, issues from the walls of a cave or fissure about 23 feet high, and the thickness of its vault is perhaps another 3 feet. Besides, the situation of the hill and the rock of which it is composed, which being of pure marble is admirably calculated to procure beautiful building materials as well as excellent lime to cement them, are all inviting circumstances to convert it into a quarry; thus, even were it considered necessary to make a cut in this part of the hill, the work would be accomplished whilst opening the quarry to procure the necessary materials.

The river Monetza in running under the Cerro del Convento has only to cross a distance of about a hundred and ten yards, although it passes through the very centre, and consequently the thickest part of the mountain.

Another barometrical level obtained from observations performed simultaneously at Tarifa and at the source of the Monetza showed that the level of this river is nearly the same as the stream adjoining Tarifa, the waters of which run to the Coatzacoalcos. The ground that lies between Tarifa and the source of the Monetza although level, is now and then intersected by torrent streams, the waters of which flow into the Monetza; and as these streams have their origin at a short diso tance from Tarifa, this ought to be considered as the proper spot for the division of the waters in the canal.

The houses of Tarifa are somewhat elevated in the midst of 
a ground so level, that in the rainy season it becomes inundated, for which reason this plain has been called the lake of Tarifa. Sr. Moro took advantage of this circumstance to save the trouble of a new levelling between the latter place and the Portillo, or opening of the road to the Venta, since the line left by the waters on subsiding clearly shows that the two points are nearly on a level; thus, with a cut a foot or so deep in the edge of the Portillo, the waters to the south of Tarifa would proceed towards the Pacific, whilst those on the northern side naturally run towards the other sea.

All that now was wanting was to find the manner of increasing the volume of available waters, and to avoid having recourse to the expensive means of constructing great reservoirs.

The waters of the Almoloya, Citune, and other streams on the side of the Chivela were calculated, but their distance from Tarifa, and the difficulties of the ground they would have to cross, would make their conveyance somewhat expensive; and therefore Sr. Moro resolved to examine the great river Ostuta.

At Zanatepec he experienced some difficulty in fording the river, which was rather swollen, notwithstanding which its waters continued to be perfectly clear as far as that spot. The documents deposited in the archives of the village, were examined, amongst which he found a few fragments of a map of the land comprised in its jurisdiction. This interesting document, almost entirely destroyed, may be inferred to have been executed during the first period of the Conquest; for whilst it is painted on paper, made of Maguey (agave Americana), and preserves all the characteristic signs of the Aztec works of this kind, there is on it a figure of a Spaniard by whose order the map was probably drawn; but that which most particularly attracted attention was to find noted down the traditional opinion that the river Ostuta takes its suurce in a lake.

It was with the greatest difficulty that he found any one able to accompany him in the exploration of the river. Amongst the inhabitants of the town, there were only two old men who remembered having visited a small portion of its course, and pictured with the blackest colours the dangers and difficulties of the undertaking. It would be tedious to cnumerate those 
which existed in reality; suffice it to say, that after several vain attempts, he succeeded, by following up the banks of the river, in reaching the fcot of the high hills from whence it proceeds. Throughout the whole distance the river receives no constant tributary, and its waters increase as they approach their source, which shows that a portion of them becomes absorbed in the lower part of the course of the river.

The waters of the Ostuta were not measured, not only on account of the difficulty of doing so, but because they often vary in an extraordinary manner; but it may venture to be asserted that they are never less than three times as copious as those of the Chicapa, and frequently more than six.

The wild state of the country compelled Sr. Moro to cut his way through the woods when he could not take advantage of the pathways or tracks formed by the numerous tapirs which inhabit those regions. For this reason, and also on account of the rugged hills between which the river is imbedded, it was impossibla to discover the adjacent grounds; but the direction in which he had constantly proceeded, namely, towards the north and inclining afterwards to the west, as well as the distance he had gone, made him suppose that he was near the upper course of the Chicapa. He was not mistaken, for he perceived suddenly at a short distance to the west, the Cerro Atravesado, an eminence which he had reconnoitred before to its very summit.

The elevated situation in which he was, and the proximity of the two rivers, seemed to promise that there would be no great difficulty in effecting their junction; but the intervening woods, by concealing from view the topographical aspect of the ground, did not permit a fair estimate being formed of the difficulties there might be to encounter.

The river came down precipitously from the mountains, and for a considerable distance had ceased to be fordable. It was every moment more and more difficult to ascend its course along the same bank, and at last it became evident that, in order to estimate correctly the obstacles which might oppose themselves to the projected junction, nothing else remained but to reach, if possible, the very spot where he then was, by 
descending along the craggy side of the Cerro Atravesado which lay opposite.

Meanwhile it appeared evident to him that both the Chicapa and the Ostuta proceed from that portion of these territories where the Sierra Madre is highest, which explains why these rivers increase and diminish simultaneously, without its being at all necessary to suppose that they owe their origin to a lake.

On his return from this expedition up the Ostuta he went to Niltepec, and ascended the Atravesado. The bad weather overtook him on its summit during the night, and the following day, finding it impossible to withstand its inclemency without a shelter, he was about to abandon the undertaking, when an interval of hope encouraged him to persist, and the weather, becoming more genial, rewarded his perseverance.

On arriving at the north-eastern extremity of the table-land the party found it necessary to alight from their horses and undertake the descent of the hill on foot, they did when exploring the course of the Ostuta.

The Cerro Atravesado stands completely isolated on every side, except here where it ends in a kind of ridge, and which descending to the valley is joined by another, proceeding from the summit of the Sierra Madre.

Resolving to follow the first of these ridges, in order to explore the ground which divides the two rivers, Sr. Moro was not long in reaching the point where it is most depressed, and from which the relative position of both rivers was perfectly clear and obvious.

Near to the west, was the deep ravine through which the Chicapa runs, and to the east the elevated grounds of the bed of the Ostuta, which had just been visited, and which he recognised perfectly at a distance of less than a league. The difference of level between these two points is so considerable, that there cannot be a doubt of the facility of effecting the junction of the two rivers; and it is no less evident that, in the short space which intervenes, there is no obstacle whatever to prevent it. The weather clearing up he was enabled to make several observations from points still more elevated, by means of which he ascertained beyond all question the 
favourable nature of the ground, and, as no doubt remained on his mind on the subject, Sr. Moro considered the exploration of these parts quite completed.

In these expeditions, as well as those to the Coatzacoalcos and others no less toilsome, Sr. Moro was accompanied by his friend and countryman, Don Estevan Maqueo, one of the present proprietors of the Haciendas Marquesanas, in whom the Commission found a most useful and willing assistant.

Whilst Sr. Moro was engaged in these explorations, Captains Robles and Gonzalez had returned from the Coatzacoalcos, after surveying its course from the confluence of the Sarabia to the sea.

Captain Robles went to ascertain the latitude and fix the situation of Santa Maria Chimalapa, which had not yet been obtained, and afterwards to note the course of the river del Corte from the most elevated point he could reach, as far as its confluence with the Sarabia.

At the same time Sr. Moro undertook to explore the country between Tarifa and the confluence of the Malatengo and del Corte. This part of the country is the most fertile and pleasant that it is possible to imagine. Shortly after leaving Tarifa it is truly interesting to observe, mixed together, the spruce fir-tree of the cold climates, the oak of the more temperate, and the palm-tree of the warm regions. Further on, these trees as well as beautiful green meadows of vast extent occur alternately with woods of a luxurious tropical vegetation. Trees of precious woods, wild cocoa, vanilla, \&c., are everywhere seen. The plains near the rivers, cultivated by the inhabitants of Barrio, Santa Maria Petapa, and San Juan Guichicovi, give an idea of the astonishing fertility of the soil, since the natives only come in time to burn down the brushwood, and sow without cultivation, scarcely ever revisiting their corn-fields until the harvest time.

These very circumstances made the exploration difficult. It being often impossible to examine the ground in any other way but on foot, Sr. Moro found himself beset by the tall shrubs of a luxuriant vegetation, which did not allow him to see any of the surrounding surface. 
Sr. Moro's principal object had been to find out the best line through which a canal might be opened from Tarifa to the river del Corte. From Tarifa the waters descend naturally to the Coatzacoalcos through grounds by no means too rugged, whilst the very existence of a labyrinth of hillocks, almost all individually isolated, or else joined together by ridges of an insignificant thickness, are sufficient to prove the practicability of the work, but most probably presenting numerous solutions of the problem.

Sr. Moro ascertained the situation of various points, rectified some erroneous notions previously admitted, respecting the course of the principal rivers which flow into the Malatengo, and followed the course of this river from its junction with the Chichihua for about two-thirds of the distance which separates it from the river del Corte. Throughout the whole of this space its course is neither rapid nor tortuous; and although it was the season when its waters are lowest, it carried a volume of more than fifteen cubic metres per second.

Captain Robles accomplished also satisfactorily the exploration of the river del Corte, although the bad weather and other unfavourable accidents had molested them both considerably. His reports form the subject of the next chapter.

Sr. Moro immediately set out again and reached the river del Corte, passing through San Miguel and Santa Maria Chimalapa with the view of inspecting that part of the country which he had not yet visited.

He next went in company with Captain Robles to San Miguel, and again examined the brow of the Sierra, which limits towards the north, the course of the Chicapa and that of the Monetza, in order to become positively assured that they had not left unobserved any part which might offer an obstacle to the execution of the work. After this last inspection its accomplishment appeared to them even more easy than they had hitherto considered it.

The Commission definitively left the Venta de Chicapa where they had fixed their residence, and afterwards visited. the Hacienda de Santa Cruz, the village of Chihuitan, and the Rancheria de Comitancillo, the situations of which they fixed on 
the map, and with these last operations Sr. Moro had the satisfaction of knowing that none of the places which had been the object of research in the Isthmus had escaped his personal notice.

On the 25th of March, 1843, after nine months of toilsome labours, all came back to Tehuantepec, to prepare for the return to Mexico, as the Commission considered the exploration of the Isthmus to be now quite completed. (Appendix No. IV.) 
CHAP. V.

SURVEY OF THE RIVER COATZACOALCOS.

Rises in the Sierra Madre-examined from the confluence of the Chimalapilla all the way to the sea.-The streams of importance are, (on the right bank) the Chimalapilla-del Pinal-Chalchijapa-at the Horqueta the right branch is called Apotzongobranches re-unite near the Rancho del Mariscal-river Coachapa - Uspanapan-the creek Coatajapa, and several useful Lagoons. (Left bank) the Milagro-Escolapa-Malatengo-SarabiaTumuapa-Taltepec-the Naranjo and Penas Blancas-river divides at the Horqueta, to the left is the Mistan, forming the island of Tacamichapa-creeks Tacojalpa, Ojozapa Cuamecatan and Tacoteno-the river Calzadas branches off and enters the sea at the Barrilla.-The borders of the Coatzacoalcos and its tributaries covered with dye-woods, mahogany, and other fine trees, and forests of timber fit for ship-building.-Upper Coatzacoalcos abounds in lofty Pine trees. - Coatzacoalcos navigable for the largest merchant ships for $34 \frac{1}{2}$ miles-the Bar does not shift, and leaves two entrances-has $20 \frac{1}{2}$ feet water over its western passage-THIS IIARbour tile finest in the Gulf of Mexico.

The river Coatzacoalcos takes its rise in the unexplored part of the Sierra Madre, and the highest point in its course which we visited was at its confluence with the Chimalapilla, from whence we examined it all the way to its mouth in the Gulf of Mexico, situated in $18^{\circ} 8^{\prime} 30^{\prime \prime}$ north latitude, and $94^{\circ}$ $17^{\prime}$ west longitude from Greenwich.

The Chimalapilla falls into the Coatzacoalcos on its right bank, $4 \frac{1}{2}$ miles to the S. S. E. of the village of Santa Maria Chimalapa, and this confluence is 393 feet above the level of the sea. We were assured by the Indians that they had as- 
cended the river still higher than that point on their rafts, during six days, which may be reckoned about 56 miles, until they came to the junction of two small streams forming the river, and the courses of which were too precipitous to allow of being followed in their rafts.

On the same side, and at a short distance below the Chimalapilla, is the confluence of the river del Pinal, so called because it flows through mountains whereon the pine-timber was cut by the Spanish government to be sent to the Havannah for the masting of large ships, and for this reason this part of the Coatzacoalcos is still called the river del Corte (of the cutting).

As far as the confluence with the river del Milagro, which enters on the left bank at $1 \frac{1}{2}$ miles to the W. N. W. of Santa Maria, the Coatzacoalcos takes a precipitous course through a deep ravine, with a descent of 132 feet in the space of 12 miles. The mountains which border the channel are at first very high and precipitous, but gradually lowering and softening in their character as the mouth of the Milagro is approached, they then appear only as hills of moderate elevation, and the river has changed from being a rapid torrent, in which the rafts could with difficulty float, into a quiet stream, with only occasional rapids of small extent. The rocks on the banks of the river are of sand-stone, calcareous spar, and slate, although this last but rarely occurs. The limestone is excavated by the river, which thus appears to pass under the ruins of a bridge.

In the few small patches of level ground, on the borders of the river, the Indians of Santa Maria plant maize, tobacco, and cocoa; some of these tracts of land being only accessible in rafts, and others only by very craggy pathways.

The volume of water now filling the river is considerable, for as Sr. Moro descended, he found it to be about 57 cubic yards persecond, and the Indians assured him that it was rarely less.

Beyond the confluence of the Milagro, the river, hitherto running from east to west, follows a general direction towards the S. W. as far as the mouth of the Escolapa, and after that to the N. W. as far as that of the Malatengo. Both these rivers flow into the Coatzacoalcos by its left bank; and the 
Escolapa as well as the Milagro, and the streams which unite with it, have their sources in the desert part of the Sierra to the east of the road which leads from San Miguel to Santa Maria Chimalapa. The course of the Malatengo and its tributaries are laid down upon the map.

The hills on either side become gradually depressed, and at a short distance from the Escolapa they are very insignificant; nevertheless the rocks before mentioned frequently show themselves, forming the rapids already spoken of, and which give rise to many windings, so that the course of the river between the confluence of the Milagro and that of the Malatengo is $28 \frac{1}{2}$ miles.

Half way between the Escolapa and the Malatengo is the station of the Angostura, so called from two beds of greenstone rock rising in the middle of the river, whilst the banks of the stream, also of the same formation, are very precipitous; so that the channel, which above this spot was 33 yards wide, becomes divided into three, the widest of which is only $5 \frac{1}{2}$ yards broad. This same rock is found in some of the rapids below this, but they considerably diminish in importance.

As the Malatengo is approached, the hills reappear with more elevation and frequency on the borders, and continue the same beyond its confluence. The accession of waters to the Coatzacoalcos is now more perceptible in its greater depth, which from this place to the mouth of the Sarabia is generally from 5 to $8 \frac{1}{2}$ feet and sometimes even $16 \frac{1}{2}$ feet deep whilst in its breadth, it does not exceed 44 yards.

Next after the Malatengo the rivulet of rio Chico joins on the right bank coming from the Sierra of Chimalapa; and at no great distance on the other side enters a stream, near which is an ancient wharf called Mal Paso, so named on account of a strong rapid a little below it, and which caused it to be abandoned. At the present day another loading place is called by the same name, but this is 220 yards above the Paso del Sarabia close to the mouth of the river of the same name.

This rapid, which is the strongest to be found after leaving Angostura, is formed of various ridges of calcareous spar and granite, and occupies a space of 200 yards. The first of these 
rocks frequently occurs at the base of the hills, and often forms smaller rapids.

After the junction of the Sarabia the hills become inconsiderable, and almost entirely disappear a little below the river Jumuapa (or de la Puerta); the rapids also are less frequent and the last of them, called the Suchil, is seen just before reaching the mouth of the river Jaltepec (or de los Mijes).

The rivers Sarabia, Jumuapa, and Jaltepec enter the Coatzacoalcos on the left bank, and next to them the Chalchijapa on the right hand. The two first descend from the sierra of Santa Maria Guienagate, and although the Sarabia has much water it is not navigable, on account of its course being too precipitous, and having near its mouth a fall which impedes the entrance of canoes; but the Jumuapa can be ascended by them, in the rainy season, to the point named the Paso del la Puerta; from whence the road to San Juan Guichicovi is shorter and better than the one from the Paso del Sarabia. The river of Miges has its source in the sierra of the same name in the district of Villa Alta; and notwithstanding the rapidity of its current, it is navigable all the year round for canoes to a spot called Tutla, distant $7 \frac{1}{2}$ miles from the village of Trinadad. The distance from Tutla to the mouth, calculating by the time occupied in ascending it, may be reckoned at 50 miles. The river Chalchijapa carries also much water; the Indians of Santa Maria ascend it for five days with rafts, and then cross by land to their village, which is 38 miles distant from the point where they leave their rafts.

Between the confluence of the Chalchijapa and the point of Horqueta, where the river is divided into two branches, the stream Colorado, the rivers Naranjo and Peñas Blancas, and the stream Cuapinoloya join the river by its left bank, and the brook Churriagao by the right; the latter and the Peñas Blancas come from large lagoons not far distant.

The general course of the Coatzacoalcos from the confluence of the Malatengo to that of the Jumuapa is from S. to N.; then it runs N. W, until it meets the Jaltepec; and thence to the bar its course is N.E. The length from the mouth of the Malatengo to the Sarabia is 22 miles; from the Sarabia to 
the Jumuapa, 17 ; from the Jumuapa to the Chalchijapa, $22 \frac{1}{2}$; and to the Horqueta $40 \frac{1}{2}$ more, being a distance of 102 miles, between the Malatengo and the Horqueta.

The banks of the river, after quitting the hills, are generally from 10 to 17 feet high, without being steep; yet they are sometimes so low as to be covered in times of flood. At some few spots called cerritos or hillocks, the banks are from 40 to 66 feet high, and are composed of beds of clay. Among them, only the Oajaqueña, Tecolotepec, Churriagau, Penas Blancas, and Cuapinoloya, are worth mentioning. Below those of Tecolotepec, at the bend of the Cascajal, the river overflows its right bank, and the waters that escape, join the river Coahuapa, which unites with the Coachapa of which mention will be made hereafter.

In consequence of the low and sloping banks which here suffer the river to spread out laterally, and the slowness of the current, which after the confluence of the Jaltepec is scarcely apparent, the depth of the stream does not increase so much as might be expected; and during the dry season, shoals are even to be met with covered only by 20 inches of water. These shoals are formed of sand and gravel, and almost all of them are small. Those of any extent are, one commencing below Tecolotepec, which occupies the greater part of the bend of Cascajal; another between the river Naranjo and the bronk Churriagao; another that of Cuapinoloya between the island of this same name and one a little lower down; and lastly, that of Horqueta obstructing the entrance of the two branches of the river which is divided at this point.

These two branches again unite after having formed the island of Tacamichapa. The one to the west called Mistan is longer and narrower than that to the east called Apotzongo; the length of the first is 34 miles, its width between 100 and 110 yards, or about 20 to 30 yards less than the river was before it became divided: and the depth is abuut $13 \frac{1}{2}$ feet. Several streams fall into it, and near the extremity is the creek of Monzapa which has from 10 to $13 \frac{1}{2}$ feet of water at its entrance, and reaches nearly to the village of Tesistepec. In this creek is found the Paso de la Cienaga which is only two 
leagues distant from the village of Jaltipan; and in this same branch of Mistan is the pass of Blancos, at a distance of 13 miles from the large town of Acayucam, the capital of the district.

The branch Apotzongo is 25 miles long, and on its right bank, 18 miles from Horqueta, is the village of San Miguel de los Almagres (or Hidalgo-titlan), the first inhabited place met with, proceeding down the river. Below this point the water in this branch is constantly 20 to 23 feet deep; but a little above los Almagres between the strands of Mistan-grande and Gaviota, it is impeded by a considerable shoal.

After the junction of the two branches, the Coatzacoalcos receives on its right the rivulet Ishuatepec, the stream of Otapa, and the river Coahuapa, the mouth of which is 10 miles from the lower end of the island of Tacamichapa. The source of this river is unknown, and the district it traverses is a desert; it has been ascended in canoes for twelve days, which is the same time as that employed in going up from the bar of the Coatzacoalcos to the pass of Sarabia; schooners have also sailed up it to a sugar plantation $7 \frac{1}{2}$ miles above the entrance. At a spot three leagues higher up, it receives the river Coachapa, which, as already mentioned, collects the waters that leave the Coatzacoalcos at the turn of Cascajal. The stream Otapa comes from some small lagoons producing salt in abundance.

Four miles and a half below the confluence of the Coachapa, but on the opposite shore, is the village of La Fabrica of Mina-titlan; and at $4 \frac{1}{2}$ more below this, the river Uspanapan joins the Coatzacoalcos by its right bank.

Half way between the river Coachapa and Mina-titlan is situated on the left bank in front of an islet, the common entrance to the creeks Tacojalpa, Ojozapa, and Cuamecatan, in which the pine logs destined for the arsenal at the Havannah were formerly deposited.

Of all the villages named by Don Tadeo Ortiz, only Minatitlan and Hidalgo-titlan now remain, although their situations are indicated on the map.

The Uspanapan is the most considerable of all the numerous 
tributaries of the Coatzacoalcos; its course is wide, spreading through an uninhabited country; and although its sources are unknown, they are generally supposed to come from a range of mountains, which is often visible to the S.E. from the upper part of the Coatzacoalcos, This range has the reputation of being rich in gold and silver minerals, and has been explored by several expeditions, which ascended the river in canoes for sixteen to eighteen days, and some of them are said to have done this even for twenty-six days. On the banks of this river, at $23 \frac{1}{2}$ miles from its mouth, Mr Baldwin of Minatitlan built a schooner a few years since.

Below the Uspanapan, near a spot named Paso Nuevo, through which runs the high road leading to Tabasco, the rivulet of San Antonio joins the Coatzacoalcos, proceeding from some marshes $15 \frac{1}{2}$ miles above its mouth.

Finally, at $10 \frac{1}{4}$ miles below Uspanapan, and $5 \frac{1}{4}$ from the bar, is found on the left the confluence with the river Tierra Nueva, or the Calzadas, this being the channel by which the Coatzacoalcos unites with the river Huasuntan, which empties itself into the sea by the mouth of the Barrilla, not practicable for large vessels.

The banks of the river here are very low, and frequently flooded, and there are many creeks; the most remarkable of which are, that of Tacoteno on the left bank, below Paso Nuevo, which reaches back to near Mina-titlan, and that of Coatajapa on the right hand, which flows near the village of Yshuatlan.

The depth of the Coatzacoalcos, from the separation of the branches which form the island of Tacamichapa to the mouth of the Coachapa, is $26 \frac{1}{2}$ feet, and from this to the bar not less than 33 to 40 feet. Its breadth, where narrowest, is from 130 to 170 yards; and in some places below the mouth of Tierra Nueva it is nearly 770 yards. It will therefore be seen that as far as the island of Tacamichapa, a distance of $34 \frac{1}{2}$ miles (13 Mexicans leagues nearly), or at least up to the confluence of the Coachapa, the Coatzacoalcos is navigable in all seasons and for every class of ships, forming a convenient as well as most secure harbour. Schooners might 
ascend as far as Horqueta by the branch of Mistan, and to Hidalgo-titlan and somewhat higher by that of Apotzongo.

From the battery on the left shore at the entrance of the river, a clear channel is to be seen through the break in the bar, which we were informed never varies in position; and although we knew well that there is a sufficient depth of water for large ships (since but a few years ago two large French vessels with colonists had entered the channel), we examined it ourselves in an open boat, going out to the distance of 2 miles, where we found 50 feet of water with a rapidly increasing depth. The shallowest water we found on the bar was $20 \frac{1}{2}$ feet, and we were not certain that we had gone over the deepest part of it.* A North American pilot, who resides in the establishment of Mr. Baldwin, assured us that he had many times crossed the bar, and that he had never found less water upon it than 21 English feet. This account nearly agrees with our own observation, and confirms the old opinion that the bar does not shift, a circumstance easily explained, since the current of the river is slow, its waters limpid, and the tides are almost imperceptible at its mouth.

The abundance of ship timber which is to be found on the borders of the river itself, the convenience and security of the port, the facility of defending its entrance by placing batteries at the points of the river facing the channel, and which from the nature of the ground might be rendered unassailable from the land side, are all so many combining circumstances to render the Coatzacoalcos the fittest place in all the gulf of Mexico for the establishment of an arsenal. These advantages were first pointed out to the Spanish government by the engineer Cramer, in the year 1774. In $17 \% 8$ another engineer, Don Miguel del Corral, submitted to the Viceroy a plan for the construction of an arsenal, with two building slips for vessels of every size, and a fort to defend the entrance of the river.

In making our survey we descended the river in canoes

* When we reached the greatest distance from the land, the rusty shanks of the rudder of our boat broke, and this compelled us to return immediateiy, without taking any other soundiugs, as we had intended. 
from the Paso of the Sarabia to its mouth: from the confluence of the Chimalapilla to that of the Sarabia we floated down on rafts ; and, in laying down the course, we determined astronomically the latitudes of five points. The intermediate places were observed by compass, estimating the distances by the time employed in passing along them, which was the only method we could adopt, owing to the matted state of the forest along the banks; and in those places where some of the loops made by the river approach each other in the branch of the Apotzongo, the ground was examined on foot by paths which we had to cut for ourselves.

Not being enabled to determine by observations the position of the mouth of the river, we have adopted that laid down by the Spanish naval officers. 
CHAP. VI.

STATISTICAL NOTES OF THE ISTHMUS OF TEHUANTEPEC.

Southern Division in the Department of Oajaca-the Northern in that of Vera Cruz-Inhabitants-Climate-Minerals-Vegetables-Animals-Agriculture-Cattle-Salines-Manufactures and Industry-Antiquities.

The isthmus of Tehuantepec belongs to the Mexican Republic, and forms part of the departments of Oajaca and Vera Cruz. According to the official reports, published by the Mexican Government in December 10th, 1841, as a basis for the elections, the former department contains a population of 500,278 inhabitants, and the latter, 250,380.

The two extremities of the isthmus are the only inhabited portions, and they are separated from each other by an immense forest of astonishing beauty, which, from the richness of its natural produce contains evidently treasures of incalculable value, but which with its luxuriance conceals the aspect and form of the hitherto unexplored soil, on which it stands.

\section{SOUTHERN DIVISION. DEPARTMENT OF OAJACA.}

This part of the Isthmus is topographically divided by nature into two sections. The first occupies the plain which extends from the Pacific Ocean to the foot of the Sierra, and the second belongs to the Sierra itself.

Politically, the southern grounds of the Isthmus constitute the greater part of the district of Tehuantepec, and comprise twenty-four municipalities; the town of Tehuantepec, which the Spaniards call also Guadalcazar, is the head of the district; and the residence of a Prefect, a Judge of first instance, a military Commander, and a parish Priest. Juchitan and Petapa are the heads of two sub-districts with their respective Sub-prefects. 
Ecclesiastically this portion of the Isthmus is dependant on the diocese of Oajaca, and in addition to the parish of Tehuantepec it has five Rectories.

\section{INHABITANTS.}

The whole of the southern territory of the Isthmus contains about 31,000 inhabitants, as may be seen in the Appendix C.

The population of this division is composed of Europeans, Huaves, Zapotecos, Mijes, Soques, and Zambos.

The Europeans, as regards numbers, constitute an insignicant part of the population, and are disseminated over various localities.

The Huaves are in all little more than three thousand, and occupy the four villages of the coast called San Mateo, Santa Maria, San Dionisio, and San Francisco.

These natives are easily distinguished by their aspect, which differs materially from that of the other inhabitants of the Isthmus. They are generally robust and well-formed; some among them evince a high degree of intelligence, but the majority are grossly ignorant.

The Huaves of both sexes are habitually in a state of almost complete nudity. Their industry consists of little else than fishing, and even this they can only do by means of sweepnets: with the produce of their fisheries, however, they carry on an extensive trade, although not possessing proper vessels to venture into deep water, and being ignorant even of the use of the oar, they only frequent those spots which, from their shallowness, offer little danger, such as marshes, and the margin of the lakes and of the sea. It is a singular fact that although the Huaves are chiefly fishermen, very few among them know how to swim.

The Zapotecos constitute the greater part of the southern population of the Isthmus, and almost exclusively that of sixteen villages out of twenty-four.

The aborigines of Tehuantepec are by their civilization incomparably superior to those of any other part of the Republic; their intellectual qualities are of no mean order, and 
they are generally found intelligent, industrious, docile, and lively.

In point of personal appearance the Tehuantepecans are vigorous, and of a pleasing aspect, and among them there are many with light hair, and a complexion comparatively fair. Speaking of the women of this part of the Isthmus, they are also noted for their graceful carriage, and the regularity of their features : their gala costume is picturesque, rich, and elegant, as well as the head-dress which they generally wear.

In Tehuantepec, in particular, there are bakers, carpenters, smiths, tinkers, silversmiths, tanners, shoemakers, saddlers; and every family, whatever may be their circumstances, manufacture the soap necessary for home consumption. 'The clothes woven by the women from the wild silk and cotton, are really admirable, particularly considering the very imperfect instruments which they possess for the purpose.

The Mijes constituted formerly a powerful nation, and they still occupy the land from the Sierra, north of Tehuantepec, to the district of Chiapas. In the Isthmus they only inhabit the village of Guichicovi, and a small portion of the Sierra, which is never visited.

Physically and morally speaking the Mijes are a degraded race, of a repulsive aspect, and most grossly ignorant. They are, however, given to agriculture, and they grow plantains, maize, beans, and sugar-cane, from the latter of which they extract an impure kind of sugar, and they may be said to supply with these articles the southern division of the Isthmus.

A favourite object of the ambition of the Mijes of Guichicovi is that of possessing the greatest possible number of mules, a circumstance not easily accounted for, considering that they make no use whatever of these animals, not even for the carriage of their goods, which they prefer bearing on their own shoulders.

The Soques, who came originally from Chiapas, inhabit in the Isthmus only the villages of San Miguel and Santa Maria Chimalapa. They are easily distinguished from the other inhabitants of these regions by their peculiar features.

In point of morality the Soques appear somewhat more 
rational than the Mijes ; and contrary to these they are naturally kind and obliging.

They cultivate the scanty supply of maize required for their own consumption, a small quantity of tobacco, and two plants belonging to the family of the bromelias, from which they extract the iatle and the pita, the fibres of which they can bleach, weave, and dye of different colours. Their spun materials, and the hammocks which they weave with them, constitute their chief industry and commerce.

The inhabitants of Santa Maria extract also some annotto, and supply the whole of the southern part of the Isthmus with the delicious orange, which grows abundantly about their settlement.

The Zambos, are a half-cast between the Indian and the Negro. They are robust and industrious, working as labourers in the fields, and applying themselves to the cultivation of wheat, indigo, and cochineal. Unfortunately neither the Zambos nor the other natives of these districts are remarkable for their sobriety.

\section{Climate.}

The climate of that portion of the country, which in this part of the Isthmus extends from the shores of the Pacific to the foot of the Sierra, is in general warm and dry, a circumstance to which no doubt it owes its salubrity.

The heat is not equally intense in every part of the plain. Tehuantepec, situated in a sandy ground, open to the south and encircled on everyother side by hills which prevent the approach of breezes, the coolness of which mitigates the heat of a burning sun, is without doubt the hottest spot in the Isthmus. We have often seen the centigrade thermometer at seven o'clock in the morning rise to more than $33^{\circ}\left(92^{\circ}\right.$ of Fahrenheit.)

Zanatepec is also subject to excessive heat in consequence of the proximity of the mountains which shade it on the northern side. The other villages, especially those near the sea, being at a greater distance from the mountains, are freely exposed to the northern winds which blow almost incessantly 
in these regions, and they consequently enjoy a much milder temperature. The winds proceeding from the north, being as it were confined within the great valley formed by the interruption of the grand chain of mountains between Tarifa and Petapa, descend with considerable force through the gaps of Tarifa and Chivela. The Venta de Chicapa, situated opposite the former, receives these currents at times with great force and they are also often felt by travellers on arriving in front of the Portillo de la Chivela.

The climate of the elevated section of this part of the Isthmus is so different from that of the plains, that when the thermometer stands in the latter place at $30^{\circ}$, it scarcely rises to $13^{\circ}$ at Chivela or Tarifa. In all the heights surrounding these estates, we find the pine ocote, the presence of which clearly indicates a very temperate climate. This considerable difference of temperature appears much more strange considering that the absolute elevation of Tarifa is not more than 650 feet, whilst its latitude is less than $17^{\circ}$. Our surprise ceases, however, when it is remembered that Tarifa participates in the temperature of the Sierra, which, near to it, reaches suddenly an elevation of more than 7,500 feet.

The summits of the Sierra Madre are almost constantly enveloped by the clouds, which, coming from the Atlantic there discharge themselves, a circumstance that accounts for the rivers of the Isthmus having an almost constant body of water during the greater part of the year. At Guichicovi and Santa Maria Chimalapa it rains almost incessantly, and often also at San Miguel. Whenever such is the case the table-land of Tarifa is covered with a kind of thin mist, which disappears upon reaching the Portillo where the reigning wind becomes more powerful. This phenomenon may be considered permanent, the suspended mist rarely extending beyond the table-land of Tarifa. Thus the Venta enjoys an almost constant unclouded atmosphere, and rain seldom falls in the plains.

It cannot fail to be observed, that among the advantages offered by the isthmus of Tehuantepec for the execution of the proposed work, that of a mild and healthy climate, pre- 
cisely in those localities where the assistance of European workmen would be required, is of the greatest consideration. The small rains of Tarifa and of the valley of San Miguel are not of sufficient consequence to impede the continuation of the work during a considerable portion of the day.

During the long sojourn of the Commission in the Isthmus, they had often to undergo hard and severe toils, and were frequently exposed to the most trying inclemencies of the weather, and yet neither themselves nor their numerous attendants experienced any illness indicative of an unhealthy climate.

\section{MINERALS.}

The geological collection will give a sufficiently clear idea of this department of the subject. Iron is found in abundance in many points of the Isthmus, and that of Tarifa especially appears to be of excellent quality. As regards the precious metals, which made the department of Oajaca once so famous, there is a tradition still prevalent from the time of the conquest that the mountains of Mijes and the upper Uspanapan contain very rich gold and silver mines.

\section{VEGETATION.}

The mangrove tree (rhizophora mangel) of sinister omen is not so common on the coasts of the Isthmus as on others of the Republic. In the southern division, it can only be found in the neighbourhood of San Francisco and of the Morro.

In the peninsula of San Mateo and Santa Maria the most remarkable plants are the tamarind, the palm, and the cocoanut trees, besides which the ground is also covered with regetation. Three different species of the sensitive plant are here found in abundance, one of which attains to nearly a metre in height.

The land to the north of the lower eastern lagoon, in which the Haciendas of San Dionisio and San Francisco are situated, appear clothed with a luxuriant vegetation somewhat resem- 
bling that of the parks in Europe. The flowers in some of these localities are of astonishing beauty.

Between the coast and the Sierra the plain is partly covered by acacias, which, as we shall presently see, might furnish a considerable quantity of gum.

On approaching the Sierra the vegetation is more vigorous, and the Brazil-wood tree (cœsalpinia crista), of which considerable fellings might be effected, becomes very common. The granadillo, the mahogany tree, (swietenia mahogani), the copalchi (croton cascarilla) the bark of which is a well-known febrifuge, and the dragon-tree (pterocarpus draco) begin to make their appearance as well as many other shrubs that yield resins and balsams, to which the natives ascribe the most marvellous virtues. There are also the fustic (morus tinctoria), the log-wood (hœmatoxilon campechianum), as well as a con siderable number of other trees both picturesque and useful for their flowers and the hardness and durability of their wood.

Both the soil and the climate are favourable to the cultivation of indigo and the sugar-cane; and those tracks of land which are protected from the winds produce cotton of superior quality.

The table-land and hills between Tarifa and the Barrio appear covered with good grass which affords an excellent pasturage for cattle. The dales are covered with palm-trees, and a little higher up we find the ocote pine (pinus religiosa?) which has some affinity with the pinus picea. The latter tree is also found on the summits of the hills between the above mentioned places and Santa Maria Chimalapa alternately with the tropical plants which grow in the lower portions of the ground.

It is impossible to describe with effect the luxuriance of the vegetation in the latter places; but among the prodigious multitude of plants, however, the guayacan (diospyros lotus), the cedar, the mahogany, the rose-wood, the gateado, and the ebony, are particularly abundant. No less worthy of notice are the amber-tree (liquidambar styraciflua), from which is extracted the resin of the same name, and the tree yielding the 
balsam of Peru (myroxylon peruiferum) and the ocozotl producing a gum very similar to the true amber.

Innumerable species of fruit trees also luxuriate here, among which are found two kinds of vine bearing fine flavoured grapes, the plantain, the orange tree, two species of spontaneous cocoa (theobroma cacao) and the sapota tree of various kinds. The abundance of these is so considerable, especially that of the mammee sapota, that the Indians are accustomed to cut down the tree to gather the fruit more readily.

There are likewise several kinds of indigoferas; the bixa orellana, from which the annotto is extracted, the sarsaparilla (smilax sarsaparilla), the ginger (amomum zingiber), and two kinds of vanilla, very common, and of which no use whatever is made. This precious plant is also found in great abundance on the hills west of Petapa.

The Cerro Atravesado has on its summit a table-land, at the northern extremity of which rises an isolated peak. It is covered with excellent pasture grass, and a splendid wood of ocotes. The fissures by which the table-land is intersected are constantly supplied with delicious water by the frequent rains, and when these are considerable, the superabundant water falls perpendicularly over the western side, forming a cascade nearly three thousand feet in height. The edges of the fissures are richly ornamented with zamias, ferns, and orchidaciæ of great beauty.

The southern side of the most elevated portion of the chain is profusely covered with majestic oak trees.

To the right of the upper Coatzacoalcos, or river del Corte, are found in astonishing abundance various kinds of pines, and among them it would appear is the pinus abies which the Spanish Government used to send to the dockyard at the Havannah for the construction of masts for ships. According to Don Tadeo de Ortiz many of these trees are from six to twelve feet in diameter, and of a prodigious height ; they are found at the very banks of the river. The plains watered by the rivers Malatengo, Chichihua, and Almoloya (the latter of which takes in its lower course the name of Guelaguesa) are 
noted in the Isthmus for their delightful aspect. The vegetation in them is similar, and perhaps even more luxuriant than that of the low grounds on the road to Santa Maria. The soil and climate are likewise peculiarly adapted to the growth of maize, coffee, cocoa, tobacco, rice, and the sugar-cane.

On the road from Boca de Monte to the Mal Paso the vegetation begins to assume an aspect peculiar to the plains of the Coatzacoalcos. The laurus sassafras, the fern tree, an infinite variety of palms, and the plants of the tropical regions already alluded to, united and interwoven with passion flowers, and innumerable filamentous reeds, or richly enveloped and crowned by a multitude of exquisitely beautiful orchidaciæ formed an admirable and sublime spectacle. But the peculiar characteristic of these shrubberies is, that the plants concealed in the midst of this luxuriant regetation appear desirous to reach as soon as possible an elevation where they may enjoy the rays of the sun, thus acquiring an extraordinary height, and their stems being remarkably straight.

The Sarabia also runs through groves and woods of great beauty, the soil of which seems to be waiting only for the helping hand of man to yield with profusion the natural riches it contains.

\section{ANIMALS.}

The wild beast most common in the Isthmus is that which is improperly called a tiger by the inhabitants of the Republic, it being in reality the ounce (felis uncia); after this comes the American lion or puma (felis discolor): they are both numerous, although they are said never to attack a man, probably because they have other prey in abundance. The ocellots or small tiger (leopardus pardalis), the wild cat, and particularly the American fox (vulpes fulvus) are also very numerous in the Isthmus; but their skins are not turned to any account by the natives.

In every one of the different estates of the Isthmus a tigrero (tiger-hunter) is kept, who with a numerous pack of hounds is exclusively engaged in destroying the wild beasts which cause serious damage among the herds of cattle, notwithstanding 
the immense number of deer, hares, and rabbits on which they could and do also prey. As soon as the dogs discover one of these animals they set off in pursuit, and soon compel him to climb a tree for protection, where he is quickly dispatched by the tigero's rifle.

The most remarkable animal in this country, in respect to its size, is the tapir (tapirus terrestris), which is found in great numbers in the upper course of the rivers Chicapa and Ostuta, as well as in all the wild spots of the Sierra affording good pasture and an abundant supply of fresh water. The fiesh of this animal has an agreeable taste.

In the upper Ostuta there are also considerable herds of wild cattle, proceeding no doubt from those which escaped into the woods from the old estates called Frailescas.

In the river just mentioned, as well as in all the others above named, there are a great number of martens of a particularly beautiful species.

In this part of the Isthmus two kinds of the hog are very common, one called the wild boar throughout the Republic, although it bears no resemblance to the animal known by this name in Europe; the other, the pecari, dicotyles tayacu of zoology. The male of this last has on the back a gland that contains a fetid humour, but its flesh, especially that of the female, is delicious food.

The woods swarm with an immense number of monkeys of the genera lagothrix and ateles.

The deer, rabbits, and hares are innumerable in the Isthmus, and the quantity of the latter which are constantly passing by the traveller in the plains of the southern coast is almost incredible.

From what has been already said of other animals, the abundance of the feathered tribe in these regions will naturally be inferred. Of these the crax alector, improperly called pheasant; the wild turkey (meleagris gallo pavo); the chachalaca (ortalida garrula); the partridge, the quail, the wild pigeon, and ducks of various kinds are particularly remarkable.

Among the birds the most deserving of attention for their beautiful plumage are those of the parrot kind, the toucan 
and on the shores of the lagoons the platalea ajaja of a beautiful rose colour.

Among the reptiles are found the iguana, the flesh of which is considered by the natives delicate food. Unfortunately too there are also the most dangerous kind of serpents, such as the rattle snakes (crotalus horridus), the coral coloured, and many others.

Lastly, of the natural products of the country those yielded by the Insects of the Isthmus ought not to be overlooked. The most remarkable of these are the honey and wax with which the bees fill the woods, and the enormous bags of raw silk suspended by small worms from the branches of trees which the women of Tehuantepec turn to no small account.

\section{AGRICULTURE.}

Appendix C. Table 2, exhibits the private landed property existing in the southern part of the Isthmus.

The produce most in requisition with all the inhabitants of Isthmus, and in general of the whole Republic, is maize, of which they make the tortillas (small cakes), and which is their principal food.

The Indians of Guichicovi are the most active cultivators of maize; but the harvest, which in proportion to the quantity sown they reap in great abundance, is due much more to the fertility of the soil than to the intelligence or art of the cultivator. Tehuantepec and San Miguel are the only places in the Isthmus where the maize plantations are artificially watered.

Some attention is also paid in this part of the Isthmus to the cultivation of the sugar-cane. There is a sugar factory in the neighbourhood of Chihuitan, belonging to Messrs. H. Gobert and Olivier Gourjon, the former a German and the latter a Frenchman. According to the note taken by Don Pedro de Garny, this establishment, founded but a few years ago, can yield 100,000 lbs. of sugar, representing there a value of $£ 1800$, and $£ 800$ more for the brandy distilled from the molasses. 
The consumption of the whole district of Tehuantepec, may at present be considered to amount to about $250,000 \mathrm{lbs}$.

The Indians of Guichicovi especially, manufacture an impure sugar, used for the confection of brandy. This spirit is chiefly distilled at Tehuantepec, Juchitan, and Itztaltepec. The total value of the brandy consumed in the southern part of the Isthmus is estimated at $£ 1600$ to which ought to be added $£ 1200$ more for the mescal, a kind of brandy extracted in those places from the leaves of the American agave.

The most important agricultural produce in this part of the country is that resulting from the cultivation of indigo.

It is of such excellent quality as to be in request in all parts of the Republic, and it is also exported abroad. An average crop will produce about 120,000 lbs. representing a value of $£ 24,000$. Its cultivation demands scarcely any attention, as the plant continues to be productive for the long period of three years. It has been often calculated that the expense of the producing of indigo in fruitful years, does not exceed $1 \mathrm{~s} .6 \mathrm{~d}$. per $\mathrm{lb}$. whilst its value is never less than $4 \mathrm{~s}$. per lb.

The settlements where this important cultivation is most flourishing are Juchitan, Itztaltepec, San Gerónimo, Chihuitan, and generally throughout the whole districts of Tehuantepec.

After the indigo, the iztle and pita are among the most considerable productions, but we are without sufficient accurate information to venture an assertion respecting their true value, which is also the case respecting tobacco, annotto, wax, honey, and wild silk.

It is ascertained that the cochineal insect of these parts is the best in quality of any known, but its cultivation is almost entirely abandoned. Gum is so abundant, that according to the assertion of Don Pedro de Garay the neighbourhood of Juchitan alone will furnish 600,000 lbs. valued at about $£ 3200$.

\section{CATTLE.}

Formerly numerous herds of cattle grazed in the southern division of the Isthmus. Don Tadeo de Ortiz says that in the Frailescas estates alone there were more than 30,000 head of 
horned cattle, besides a considerable quantity of horses. At present they have not more than 1500 of the former, and only a few hundreds of the latter.

Table No. 2 shows that the whole of the black cattle in this district amounts to some 44,000 head, one-fourth of this number occupying the Marquesanas estates.

The number of horses and inules may be estimated at 25,000 , and that of the sheep at 1500 . No use whatever is made of the wool.

\section{FISHERIES。}

The lagoons, the rivers, and the ocean contain a variety and quantity of fish truly astonishing, as well as a considerable number of tortoises of various kinds. The divers of other parts are in the habit of coming to the neighbourhood of the Morro in quest of the valuable tortoise-shell, coral, and pearl, which these coasts contain in abundance. The alligator inhabits the lakes near the coast. The natives of Tehuantepec find also near the Morro a kind of purple shell-fish, from which they extract a substance which is much in use among them as a dye.

The shrimp and dry fish prepared by the Huaves in the four villages of the coast, besides providing for the consumption of the inhabitants of the country, are sent in rather large quantities to Oajaca, and other points of the Republic.

\section{SALT PITS.}

Salt pits are so numerous, that it would be difficult to determine the quantity they yield; but from a proximate calculation, made with the assistance of some well-informed persons, their produce may be estimated during the period when they were worked on account of the government at 75,0001bs; and it may be asserted with truth that the whole of their produce was not turned to account, sirice it is no exaggeration to say that from Huamelula to Tonala the entire intervening space is one continued salt mine.

This salt is highly esteemed in various parts of the Republic, both for its purity and its whiteness. The principal con- 
sumption takes place in the departments of Chiapas and Oajaca, the annual produce derived from it being about $£ 8,000$. This salt was sold at the public administration of Tehuantepec at $2 \mathrm{~s}$. $5 \mathrm{~d}$. per lb. Its cost to the government was not more than $6 \mathrm{~d}$. for every $100 \mathrm{lbs}$. since being of spontaneous formation, and not requiring any operation whatever, the expense was limited to the mere carriage from the works to the place of deposit.

\section{MANUFACTURES.}

Those for which the inhabitants of the Isthmus are more distinguished are leather-dressing and saddlery. At Tehuantepec and Juchitan doe-skins are prepared of any colour required, and with a degree of skill which entitles them to the high repute they have attained. Other kinds of skin are also tanned there, and the sole-leather and dressed ox-hides of 'I'ehuantepec are much esteemed. Shoes and saddles manufactured of them are occasionally sent to Guatemala and the interior of the Republic.

Another produce of the industry of the inhabitants of the Isthmus consists in cotton stuff, woven with an admirable degree of fineness, considering the imperfection of the looms employed for its manufacture.

\section{NORTHERN DIVISION OF THE ISTHMUS.}

\section{DEPARTMENT OF VERA CRUZ,}

This portion of the Isthmus belongs to the district of Acayucam, which was formerly one of the most densely populated of the Mexican empire.

The government of Vera Cruz published, in 1831, the statistics of their own territory, and Don José M. Iglesias edited with accuracy and tact the portion relating to the district of Acayucam. Since 1831 the condition of this country has considerably improved, as may be inferred by the buildings 
now in progress in the chief town of the district, as well as by the flourishing plantations of cotton and tobacco, not one of which existed at that time, but which have since acquired some importance.

The topographical knowledge of these regions is necessarily very limited where forests of immense extent and almost impenetrable thickness render the work of exploration difficult. It is, however, particularly characterised by the course of the Coatzacoalcos, which the Commission examined, and it is known that the ground on both sides of this river is traversed by streams of scarcely less importance, the waters of which might be advantageously employed to facilitate the communication between this fertile territory and the adjacent districts.

After the river Coatzacoalcos, the next in importance is the Uspanapan, which according to Ortiz "runs through a "pleasant and picturesque region of temperate climate, and "once thickly populated." This region, he thinks, is that which Cortes and Clavijero called Chimatlan and Quiexula.

"It is very probable," says Ortiz, " that this district, " which is now deserted, may afford a short and regular tran"sit to the beautiful plains in the centre of the Isthmus, as " the conquerors penetrated through it into the Upper Tabasco " and Guatemala."

Besides the Uspanapan, the rivers Coahuapa, Coachapa, San Antonio, Tancochapa, and Zanapa, water also the plains lying on the right of the Coatzacoalcos: all of them are more or less navigable, and the latter discharges itself into the Atlantic, about 25 miles eastward of the mouth of the Coatzacoalcos, through the bar of Toneladas, which the mariners of old mention in their writings as a frequented port, and which is well worthy the attention of modern navigators.

The territory west of the Coatzacoalcos is also intersected by large rivers, among which the Jaltepec and the San Juan are the most remarkable. The former, which as we have seen joins the Coatzacoalcos, runs through a country remarkable for its magnificent vegetation; and Ortiz is of opinion that a great portion of its course might be navigable for steamers. 
The latter falls into the Atlantic by Alvarado, and the Acayucans follow its course, when going to Vera Cruz, between which port and the Coatzacoalcos it is asserted that a water communication might be very easily established.

In the district of Acayucam there are sixteen municipalities.

The town of Acayucam, situated at about $17^{\circ} 50^{\prime} 30^{\prime \prime}$ north latitude, and $0^{\circ} 5^{\prime} 45^{\prime \prime}$ east of the meridian of Juchitan, is the head of the district of the same name, and the residence of a Prefect, a Judge of first instance, a military Commander, and a parish Clergyman.

Acayucam, before the conquest, was the court of one of the most powerful caziques among the tributaries of the empire of Mexico. Cortes, however, diminished its importance by founding the town of Espiritu Santo, which during one hundred and thirty-six years was the capital of the province; but the latter having subsequently been abandoned by its inhabitants in consequence of the frequent pillages to which it was subjected about the middle of the seventeenth century, Acayucam, recovered a small portion of its former importance.

The district of Acayucam, as regards the ecclesiastical division, belongs to the diocese of Oajaca, like the rest of the Isthmus.

\section{INHABIT ANTS.}

The tables formed upon the data afforded by the statistics of Senor Iglesias show that the population of this district, even if we suppose it not to exceed that of 1831, amounts to 21 thousands inhabitants, divided into Europeans, Indians, and Mestizos, or mongrels.

The Europeans are a limited number, and chiefly occupy themselves in commerce and the public administration of affairs.

The Indians constitute more than three-fourths of the whole population, and apply themselves to agriculture. These Indians are almost all Mexicans, and although very ignorant and superstitious, do not evince any perverse inclinations. Their manners and customs are somewhat loose; they are 
little inclined to work, but their natural docility leads us to believe that it would not be difficult to make them industrious and useful. They have not the disagreeable appearance of the Mijes and Soques, and if they are not to be compared to the Zapotecos, the difference is chiefly owing to the excessive use of strong spirits, as well as the habit acquired from childhood of eating earth, which deforms them, and imparts to their complexion a sickly hue.

Jaltipan is celebrated among the Indian villages of this territory for having been the birth-place of the enchanting Malinche (Dona Marina), who by her fidelity and sagacity materially assisted the conquests of Cortes.

The women of this village are famed, and not undeservedly as the handsomest throughout the district; but in common, with the rest of their sex in the Isthmus they cannot boast of very strict ideas of propriety. It is also said that the male population, instead of watching them with a jealous eye, carry their ideas of hospitality to a very peculiar length.

A singular circumstance, deserving the attention of the ethnologist, is the existence of a race of dumb people, of which there are numerous families in Jaltipan. However strange this may appear it is nevertheless certain, and the Rancho de los mudos (settlement of the dumb), established a few years since near the lower part of the island of Tacamichapa, owes its designation to the fact that the individuals are all dumb who inhabit the three or four houses which form this settlement.

The Mestizos are a mixed race of Europeans and Indians. They are in general more rational and industrious than the latter; but, like them, indulge in intemperate habits, and are much more turbulent. The number of Mestizos exceeds that of the Europeans.

\section{CLIMATE.}

The climate of this part of the Isthmus is damp, but its temperature being generally low, compared not only with the southern division of the Isthmus but even with the other coasts 
of the Atlantic, it is by no means unhealthy, as its position would lead one to suppose. The centigrade thermometer does not reach in these regions more than 30 degrees; the most prevalent diseases are intermittent fevers, but no instances have thitherto been known of the yellow fever, endemic in other countries.

By means of considerable felling of timber and the cultivation of the ground, the climate of this portion of the Isthmus will no doubt be considerably improved.

\section{MINERALS.}

Information purely traditional supposes the existence of rich mines of precious metals at the head of the rivers Jaltepec, Uspanapan, \&c.

In the statistical account of Don José Maria Iglesias mention is made of two mineral veins in the neighbourhood of the village of Joteapa, which were "denounced"* in 1597 as being of silver, but the exact nature of which in reality is not yet known. It is stated in the same work that the calcareous rocks found in several parts of this territory might furnish excellent building materials ; that in the settlement of los Quemados there is beautiful alabaster, and near Jaltipan gypsum of excellent quality. Lastly, it is stated in the villages of Sayultepec and Moloacan there are fountains of petroleum; in the last mentioned place and Almagres are sulphureous springs, and in the village of Chinameca a fountain of mineral waters, without mentioning its qualities.

Sr. Moro has been fortunate enough to be the first to find in the Mexican Republic mines of coals of a superior quality, which he has already legally " denounced," and the circumstance of their being situated in the neighbourhood of a great river would render the conveyance of their produce very easy. No indication has been seen in the Isthmus of the existence of this valuable fossil, but certain analogies of geological formation suggest the probability of its being found in a particular spot between Tehuantepec and Oajaca. He did not wish to

* The legal term for demanding the grant of a mine. 
omit these observations, on account of the importance of the subject in connection with our main object.

\section{VEGETABLE PRODUCTIONS.}

All the plants mentioned, speaking of the southern division of the Isthmus, are also found in the northern, but with a profusion incomparably greater. The luxuriance and majestic appearance of the forests of the Coatzacoalcos are beyond all description, and as Don Tadeo de Ortiz well observed, they exhibit "a truly monstrous vegetation, of which ocular inspec" tion alone can give an adequate idea."

In the description of the course of the Coatzacoalcos, all the large timber fit for ship-building has been already noticed.

In almost all the rivers, and especially in the Jaltepec and Uspanapan, the pine is found in the upper part of their course; then comes the majestic oak, and in the lower part the most precious woods. Among those used in construction, the cedar, the sapota, the oak, the yellow-wood, the ebony, the javicue, macayo, and above all the paqui (iron-wood), which from its extreme hardness is also called there quiebra hacha (breakaxe).

Along the whole coast of the Atlantic the tree which produces the kind of pepper known by the name of myrtle (myrtus pimenta) is found; and according to the calculations of Senor Ortiz, this fruit might be gathered annually to an amount of $£ 10,000$.

In various parts, but particularly in the neighbourhood of Jaltipan, the Jatropha elastica has been observed, from which the caoutchouc, or India rubber, is obtained. In other spots the cassia is also very common. Fruit trees are almost innumerable: the sapotas of various kinds, the lemon, the orange, and the wild cocoa tree being remarkable among them, as well as two kinds of vine. The vanilla, the indigo plant, and the sarsaparilla are also very plentiful.

In the neighbourhood of Mina-titlan are found two species of the sensitive plant one of which is the common mimosa pudica so generally known, and the other grows as a bush 
upwards of two metres in height. It would be useless to add that the most beautiful flowers are everywhere to be found, and that a great quantity of gums, resins, and balsams form a part of the rich produce of this magnificent vegetation.

\section{ANIMALS.}

The quantity of wild animals which infest these territories is almost innumerable, particularly in the neighbourhood of the settlement of Teposapa, according to Senor Iglesias. The tapirs, the deer, the rabbits, \&c., are still more abundant ; but surpassing all in number, is the tribe of monkeys, that delight in a plentiful harvest from the constant profusion of fruit by which they are surrounded. Many of these belong to the classes before named when speaking of the southern division of the Isthmus, while others are peculiar to the woods of the Coatzacoalcos, among which are some nocturnal species, and the stentor ursinus that frequently breaks the silence of the forest with his shrill and powerful cries, so loud indeed, that, judging only by its power, any one not seeing the insignificant little animal from which it emanates, would suppose it to be of considerable size.

Following the course of the Coatzacoalcos, its banks abound with the so-called pheasants, the wild turkeys, the pigeons, partridges, ducks, and many other fowl, the flesh of which furnishes wholesome and delicious food.

The multitude of parrots which inhabit this country is really astonishing. There are also a great number of toucans, especially as the inhabitants of the Isthmus include among these, without any distinction, the ramphastos and the ptercglossus. As regards other kinds of birds, their variety almost baffles calculation; some of them being remarkable for the beauty of their plumage, and others for the melody of their song.

The waters of this district abound in excellent fish. In the lower part of the Coatzacoalcos the manatus, called, from its size, the sea-cow, is frequently found. A peculiar kind of fresh-water tortoise deposit on the banks of these rivers great quantities of eggs quite different from those of the sea 
tortoise, and very similar to those of the hen, both in appearance and flavour.

The coasts of the Atlantic belonging to the Isthmus are celebrated for the abundance of tortoise-shell they afford, the fishery of which gives employment to the industry of the inhabitants of Campeachy.

The iguanas, the flesh of which is a delicious morsel to the natives of the Isthmus, differ in the southern and northern divisions. In the former they inhabit the dry and barren spots, and are of a dusky-brown colour, whilst those of the Coatzacoalcos are of a light green, variegated in the males with beautiful red spots.

In the oak forests of this district there are vast quantities of bags of wild silk, and everywhere wax and honey in abundance.

\section{INDUSTRY.}

Agriculture, however, which in 1831 might be considered almost nugatory, has made some progress of late years, and several of the inhabitants have applied themselves to the cultivation of cotton and tobacco, although I am unacquainted with the respective amount of these products.

The cotton grown here appears to be of excellent quality, and also the tobacco, which is especially cultivated in the territory of Jaltipan, where the natives understand well its management. The grains more generally sorvn are maize, beans, and rice, but only in sufficient quantity for home consumption.

The soil is so fruitful that both Don Tadeo de Ortiz and Don José Maria Inglesias assert, that the efforts of the cultivator are in some places rewarded with five annual crops of maize; each of these crops is distinguished by a different name, being respectively called tornamil, tepachole, temporal, tepeta, and etopil. Senor Ortiz, speaking with enthusisam of this fertility, says: "that which most particularly characterizes this " privileged region, however, is the singular fact that one " single sowing of rice, will yield successively two large crops "without the slightest additional labour, as I had an oppor- 
" tunity of observing in the rancho de Gavilanes situated in " the strand between the rivers Coatzacoalcos and Toneladas." The sugar-cane, coffee, and cocoa prosper throughout this district, and are cultivated in the neighbourhood of almost alt the settlements, although in very limited quantities. On the Coatzacoalcos, the only plantation of any importance is one of coffee and cocoa, which an European settler established a few years ago, near Hidalgo-titlan, on the banks of this river, opposite to this village.

The iztle is chiefly cultivated at Jaltipan, Soconusco, Tejistepec, Oteapa, Ishuatlan, and Moloacan. In 1831, Senor Iglesias numbered 1221 iztle plantations, the produce of which, generally sent to Vera Cruz, he estimated at upwards of $£ 4,000$.

\section{ANTIQUiTIES.}

The southern division of the Isthmus is particularly rich in antiquarian remains.

1. The road which leads from Mexico to Tehuantepec, on arriving in front of the Mistequilla, crosses a defile overhung by an eminence, called in the Zapoteco language Guiengola, which means large stone. In the historical manuscript, which has been alluded to, it is observed that when king Cosijoeza began his struggle for dominion against the emperor Montezuma, he made on this hill, which he had previously fortified and well supplied with arms, ammunition, and provisions, the brilliant defence which secured to him the sovereignty of these lands. It appears that in those times there were in the hill several springs of water, of which not the slightest trace now remains; but there are still to be seen, as Sr. Moro was informed, splendid ruins of fortifications and vast barracks. There is no doubt whatever of the existence of these ruins, and the Commission intended to have visited them had not other duties of more importance prevented it.

2. The hill of Coscomate, near Zanatepec, is also called the hill of the sun and moon, from two colossal representations of these heavenly bodies carved in the solid rock, which are described as illustrated by an inscription in unknown characters. The 
name of Cerro del Venado (deer hill) is likewise attributed to an effigy of this animal being hewn out of one of the rocks.

3. The old men who accompanied Sr. Moro in one of his expeditions to the upper Ostuta, pointed out the situation of a valley about nine miles east of the Cerro del Venado, where they found the remains of a large town with buildings of stone. None of these spots were visited by the Commission.

4. Any object which has been shaped by nature into a fantastic form is considered as enchanted by the inhabitants of the Isthmus. Thus they designate with this epithet the caves of the cerro del Convento and of the upper Chicapa; the Cerro Atravesado ; the problematical lake of Ostuta ; and above all, the island of Monapostiac, more generally known as the $E n$ chanted Hill.

In the manuscript just alluded to, it is mentioned that king Cosijopi at the beginning of his reign offered up a solemn sacrifice to the greatest idol of the Zapotecos, called the Heart of the Kingdom, which was placed in this island.

From the commencement of operations the highest point of the Monapostiac was fixed upon as the vertex of one of the first triangles of the trigonometrical net. The intelligence of the determination to proceed thither and fix upon it a signal, caused the greatest astonishment and terror among the natives. It was said a furious storm was sure to arise on nearing the island, and the loss of the party was considered inevitable.

Nor is it surprising that these ignorant people should entertain superstitious ideas respecting this island, since the formation of it naturally excites considerable wonder, even in the minds of the well-informed. From the summit, to the base which lies in the waters of the lake, it is composed of huge blocks of green sienitic stones, confusedly thrown one upon another, as if a heap of rubbish; and when these stones are struck together they emit a sound not unlike that of a large bell. In Sr. Moro's account of the Survey, an hypothesis was ventured upon the singular structure of this island, supposing that it came out in a state, if not of positive fusion, at least one of incandescence, and that it broke into pieces by the uneven contraction of the matter caused by the surface, from being ex- 
posed to the air, cooling sooner than the centre. The movement of the successive strata might afterwards have displaced the upper fragments, giving to the whole its present aspect. Should this be a mistake, it is, however, that which naturally occurs on seeing the Monapostiac, and its regular formation appears difficult of explanation in any other way.

The idols which were found in this island are of terracota, and have been deposited in the national museum of Mexico. Their character is very different from those made by the Aztecs, and some of them are not without artistical merit. Unfortunately during their removal the best were broken in such a manner as to prevent the possibility of joining the fragments.

It was asserted that the island of Tilema possesses also several objects of archæological interest, and that in the island of Arrianjianbaj, which signifies old city, the remains of an abandoned small town are still to be seen. 


\section{CHAP. VII.}

\section{PROJECTS.}

Correction and Clearance of the Course of the Coatzacoalcos-closing the entrance of the Mistan-Clearing entrance to the Boca Barra -Deepening the Channels of the Lagoons.-First Project-Waters of the Ostuta and Chicapa led by water-courses to Tarifa-summit level between the Monetza and Tarifa-Line of cuttings on both sides through Argillaceous rocks, marl, clay, sands, and slates.Second Project-The summit level at the Portilla, and descent to the Chicapa, using its channel.-Third Project-Summit level at Tarifa, thence by the beds of the Chichihua and Malatengo to the Coatzacoalcos; and by the Monetza and Chicapa to the Lagoons.

The various plans which Sr. Moro has submitted are formed on the supposition of the Coatzacoalcos being rendered navigable as far as its confluence with the Malatengo; and the Boca Barra of San Francisco being cleared for the admission of large vessels; and both these ends are, in his opinion, attainable without having to overcome extraordinary difficulties.

The favourable and useful pecularities of the Coatzacoalcos soon attracted the notice of its early discoverers. Cortes speaking of the country of which the Isthmus forms a part says :

"I had heard that in a very great river which runs through " the said province and falls in o the sea, there was an excel" lent harbour for vessels; because Ordaz; and those who ac" companied him had examined it, and as the country appeared " particularly fitted for colonization, and there being on this " coast such scarcity of harbours, I was desirous of finding one, " and establishing there a settlement." 
Subsequently, by order of Cortes himself, Ordaz founded the town of Espiritu Santo, four leagues from the mouth of the river, of which only some slight traces now remain it having been ruined by the ravages of the Buccaneers.

No one ever visited the Coatzacoalcos whether acquainted with these matters or not, without being impressed with the facility with which the whole of it might be made navigable.

The stability of its bed is owing both to the slowness of the current, which prevents its excavating the bottom and banks, and to the clearness of the waters, which carry no materials down to make new deposits. The gentleness of the current may be inferred from the fact that its course, with all its windings from the confluence of the Malatengo to the sea, measures 160 miles with a fall of only 130 feet.

It has been observed that the bar of the Coatzacoalcos is permanent, and in the survey of its course, in 1825 by General Olbegozo, we find, after a lapse of eighteen years, that the same windings exist throughout. The islets and streams are also identical both in number and importance, which seem to promise that whatever works may be necessary to give greater depth to the river will have a permanent result if they are well conceived and properly executed.

The usual engines might be used, as well as the power of the river itself, by narrowing temporarily its bed. This object might be effected by means of dikes constructed with solid piles, taking advantage for the purpose of the useful materials which nature herself offers profusely in the large trees and excellent clay that cover the banks of the river.

In some of the upper parts of the river it may perhaps be necessary to straighten its course, checking the increased current by means of a lock, and in others to construct solid embankments so as to limit the width of its bed; but any attempt to determine at present the number and magnitude of these works would only evince either want of good faith or presumptuous ignorance.

To change the established course of a mighty river is one of the most delicate operations in hydraulics, and requires not only much skill and tact, but a careful study of local circum- 
The two most difficult points are the rapids of the old and the new Mal Paso, where the river runs upon a rocky led; but these are of limited extent, and the many efficient means employed in similar cases are too well known to allow of much importance being attached to such obstacles.

With these two exceptions the remaining rapids are generally caused by shingle and sand-banks, and diminish gradually in number until they become very rare below the river Jumuapa.

After passing the small hill of Cuapinaloya, the Coatzacoalcos divides itself into two branches called Apotzongo and Mistan. If the former of these were straightened, compelling at the same time the whole of the waters of the river to run through its channel, and obstructing the entrance of the other arm, the shoal of Horqueta would be removed, and the river become navigable for large vessels to a point beyond Cuapinoloya, namely, more than 62 miles from the mouth of the Coatzacoalcos.

Before dismissing this subject it is necessary to make one other observation. The various authors, who have spoken of the Coatzacoalcos, differ in their statements as regards its depth,

$\begin{array}{lll}\text { Dampier states it to be } & 14 & \text { English feet. } \\ \text { Cramer }, & 18 & \text { Castilian feet at mid-tide. } \\ \text { Orbegozo ", } & 14 & \text { Castilian feet. } \\ \text { Robinson }, & 22 & \text { English feet, and more in the rainy } \\ & & \text { season. }\end{array}$

The last Commission 6,40 metres, or 21 English feet.

These apparent contradictions will disappear if we observe with Don Tadeo de Ortiz that the bar has two channels, the depth of one varying at different seasons of the year from 18 to 23 feet, and that of the other from 12 to 15 . It is not likely that all have measured the deepest channel, besides from the opportunity which Sr. Moro had of examining the plan of the soundings made by Cramer, he thinks he may with certainty assert that the bar has increased in depth.

If regulating the course of the Coatzacoalcos may be pro- 
duciive of some trouble, there would at all events be very little in opening the shoal of the Boca Barra of San Francisco, and giving more depth to a canal in the lakes, the bottom of which is nothing but mud and shingle.

These difficulties once conquered, nothing remains but to convey a sufficient quantity of water to an elevated point from whence it may be distributed and directed on the one side to the Coatzacoalcos, and on the other to the upper lagoon. Both objects may be attained by different means.

\section{FIRST PROJECT.}

This would be to open a trench that would lead the waters of the Ostuta to the valley of the Chicapa; and another, which beginning a little above the "Ultimo Kancho," would direct the waters thus collected to the table-land of 'Tarifa, following the brows of the hills to the north of the valley watered by the Upper Chicapa and the Monetza. These two proposed trenches are shown in the plan of the southern part of the Isthmus. The point of distribution of the canal would be placed between the Cerro del Convento and the estate of Tarifa, from whence it would descend on the one side to the Coatzacoalcos following nearly the natural course of the waters, and on the other would reach the upper lagoon, descending along the eastern and southern sides of the hills of Masahua by means of proper locks. By the annexed geological plan it will be seen that the proposed canal would have to be cut through a soil formed in some parts of an argillaceous rock of excellent quality, and in others of marl, clayish sand, and slates. All these rocks are easy to excavate, and of sufficient consistency to require no revestments. Now and then among the slate, the quartz makes its appearance, but we have always found it so broken as to cause no difficuity whatever.

General Orbegozo saw in the ordinary fissures of the slate a considerable obstacle, supposing that through them the waters might escape, but it would not be at all difficult to remedy this inconvenience by stopping such joints as might require it both in the bed and sides of the canal with a good hydraulic 
cement, or still better, by taking advantage of the prodigious quantity of asphaltum found in the environs of Alvarado, which the sea is continually casting on the banks of the Coatzacoalcos.

The alluvial soil, which extends from the foot of the Sierra as far as the lagoons, being for the greater part sand, might offer another obstacle, were it not that the observations which were made in two different points at a considerable distance from each other in the grounds of the Venta de Chicapa, show that at 13 feet from the surface, that is, at a much less depth than that required for the canal, there is found a very consistent clay upon which might be erected the revestment walls and other necessary works.

No less firm is the earth that was lately found on opening a well in the village of Juchitan at more than 36 feet from the surface.

\section{SECOND PROJECT.}

The second combination, undoubtedly easier and more economical than the preceding, would be to direct to the Portillo of Tarifa, that part of the canal which goes towards the Pacific, and from thence along the brow of the hills to the east, join the canal to the river Chicapa, which would be made navigable as far as the plain.

\section{THIRD PROJECT.}

After having conveyed to the immediate neighbourhood of Tarifa the waters of the Ostuta and Chicapa, by the means shown in the first project, the next consideration would be to take advantage of the beds of the rivers, which from that point proceed towards both oceans, regularising their courses so as to make them navigable. The stream of 'Tarifa, and the rivers Chichihua and Malatengo, might be followed on the one side, and on the other the Monetza and the Chicapa.

It would not always be possible or convenient to follow the windings of the rivers, but by carefully observing the ground considerable saving of labour might be effected in the work 
of excavation. The windings of the Monetza and Chicapa, judiciously turned to account, would give to the canal a more extensive line in which the locks could be better distributed. The solid rocks, through which these two rivers run, would afford both at the bottoms and sides a firm foundation to the necessary works.

The Commissioners do not pretend to have indicated the only means of effecting the desired canal transit, much less do they flatter themselves of having proposed the best, and only hope to have been the means of showing the practicability of the undertaking. With regard to its advantages as a commercial speculation, the following estimate of the necessary expense will afford the best means of calculating them. 


\section{CHAP. VIII.}

\section{ESTIMATES OF EXPENSES.}

All materials upon the spot.-Calculations based upon the first project. -Caledonian Canal taken as the model-Cost of 120 locks-50 miles of Canal-Water courses of 18 miles between the Ostuta and Tarifa-Correction of the Coatzacoalcos-Total calculated cost $£ 3,380,000$. - Sales of Land and produce will aid in carrying on the work-Provisional train and railways during the formation of the Canal.

Dutens, speaking of the Caledonian Canal, which he visited before its completion, observes, that " in a great un" dertaking of this kind it is impossible to pre-estimate the " cost of every part." And so it is: the amount of expense is mostly influenced by eventual causes, by the mode of husbanding the funds, and by the skill with which the engineer conducts the work.

If in Europe, where it is comparatively easy to obtain correct data in these matters, it is considered venturesome to name beforehand a sum as the probable cost of an undertaking of this nature, it must necessarily be more difficult to do so in the present case, from the want of the requisite particulars. However, by making use of proper investigations, and tending to over-estimate the expense rather than to diminish it, more cannot be expected in our present disadvantageous position, than an approximation to the truth.

It would be an error to suppose that every portion of the work must, in our case, cost more than it would in Europe. The prodigious quantity of timber of the best quality which the projector is authorised to use at pleasure, in virtue of the 
grant made to him by Government, and which lies profusely in every part through which the canal would pass; the excellent kinds of building stone, the lime, bitumen, clay and all other necessary materials which nature seem to have taken pleasure in scattering in the most convenient spots; and, lastly, the ground and the waters, the acquisition of which occasions often considerable expenditure, and which, in our case, if it did occasion any at all, would be so trifling as not even to be worth mentioning, are all advantages in favour of the undertaking, and which very few of the same kind in Europe could easily command.

Sr. Moro does not take into consideration these advantages, supposing them to be counterbalanced by other circumstances, and he therefore takes as a guide in his calculations the cost of an analogous undertaking, generally admitted to have been exceedingly expensive by a combination of adverse circumstances. He does still more: he applies these calculations to his first project, which as has been mentioned may be considered as the most costly, and he supposes the necessity of excavating the whole of the canal from the confluence of the Malatengo to the lagoons, without taking advantage of any of the favourable accidents of the ground.

Sr. Moro says, "the canal which I have taken as a model, is the Caledonian, the dimensions of which appear to me sufficient.* To alter them much would occasion a considerable increase in the expenditure, perhaps without a suitable compensation, whilst the alteration required in the dimensions of some of its parts for the admission of steamers destined to a transatlantic navigation, would not make it much more expensive.

"Although the Caledonian canal measures less than 22 English miles of proper channel, if we add to it the cost of cleansing and deepening the lakes, it may be considered as 25 miles long. The declivity from the top of the canal is of a medium height of 95 feet on each side, and it has in all 27 locks.

"From the statement in the Encyclopredia Britannica (7th edition, vol. 19, page 750 ) if would appear that the above-

* Excepting the length of its locks which are too short for the vessels built at the present day. 
named canal cost up to 1822 , when it was opened, the sum of $£ 905,258$, but as I find in other works that its total cost was $£ 986,924$, I will proceed with my calculation upon this last amount, although less favourable. The writer in the Encyclopædia has probably excluded from the total expenditure the cost of collateral works, such as bridges, roads, \&c., which, strictly speaking, do not belong to the canal.

"Each lock of the Caledonian canal cust, upon an average, $£ 8,000$ and therefore the whole 27 amounted to $£ 216,000$.

"Deducting this sum from the total cost, it will appear that the 25 miles of canal cost, exclusive of the locks, $£ 760,000$ and each mile $£ 30,400$.

"Selecting the proper ground, the fall of the proposed canal is :

From the table-land of Tarifa to the Pacific . . . . 660 feet. From the same point to the mouth of the Malatengo . . . . 525 feet.

"Given to it a number of locks proportionate to that of the Caledonian canal, there would be required:

On the side of the Pacific . . . . . . . 89 locks.

On the side of the Atlantic . . . . . . 72 ditto.

$$
\text { Total number of locks : . . . . . } \overline{\mathrm{I} 61}
$$

"But the number of locks depend in a great measure on the accidental form of the ground; and, these permitting, there might be given to each lock a fall of 10 feet in which case their number would be reduced

On the Pacific side to . . . . . . . 67

On that of the Atlantic to . . . . . . 53

$$
\text { In all . . . } \overline{120}
$$

"However, to come nearer to the existing data, and because it might be necessary to put one or more locks below the confluence of the Malatengo, we will suppose that the total number of necessary locks is 150 .

"The length of our canal would be fifty miles. 
"The trench, intended to convey to Tarifa the united waters of the Ostuta and the Chicapa, would be about 15 miles in length, and we will give to the section of its excavations 430 superficial feet front. According to what is actually paid in Mexico and the United States for a similar work in soils analagous to that of the Isthmus, its total cost will be about $£ 400,000$.

"The trench necessary to join the Ostuta to the Chicapa might be 3 miles in length at the utmost, and allowing for unforeseen obstacles in this part of the country on account of the nature of its rocks, we will suppose it to cost $£ 120,000$.

"Lastly, let us apply $£ 160,000$ more to regulate the course of the Coatzacoalcos and to excavate the lakes and the Boca Barra.

"Then, summing up the preceding calculations, the total amount of the work will be found to consist of the following sums :

Cost of 150 locks at $£ 8000$. . . . . $£ 1,200,000$

" 50 miles of canal at $£ 30,000 \ldots . . .51,500,000$

" 15 miles of trench . . . . . . 400,000

"3 3 miles of trench . . . . . . . . . . 120,000

Regulation of the Coatzacoalcos lakes, and Boca Barra $: 160,000$

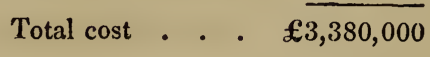

$\mathrm{Sr}$. Moro here adds some important observations to the preceding estimates which we quote in his own words:-

"I said at the commencement that it was my intention to " exaggerate the cost, and it cannot be objected that this pro" mise has not been fulfilled in the preceding calculations; for " not only have I laid aside the real advantages which the na" ture of the ground offers to the execution of the work, by " adopting the least favourable project, but I have also fixed " prices, certainly exaggerated, and by no means probable. " 1 . The ravines, which from the neighbourhood of Tarifa " convey the waters of some torrent streams to join the river "Monetza, and with it enter the valley of San Miguel, would " decrease the work at the point of distribution. " 2. I have calculated as having to open the whole of the "canal, whilst, as we have seen, advantage might be taken 
" of part of the beds of the rivers which run towards the two " opposite seas from Tarifa.

" 3 . Both the length of the trenches and the section of their

" excavation may be greatly diminished by constructing some

" dike across the valley of the Chicapa, and taking advantage

" of the favourable shape of the brow of the Sierra in some "parts.

" 4. In the Caledonian canal it was found necessary to " build a considerable number of bridges, whilst none are re"quired in our case, therefore it is evident that the average " cost for each mile of canal which I have adopted is exces" sive.

" 5. It must have been observed that I do not pretend to " attach any inportance to the traditional notion of the exis" tence of a lake, which gives origin to the rivers Ostuta and " Chicapa ; but if this were true (and it must be admitted that " there is nothing impossible in the assertion) the union of the " two rivers might probably be accomplished at their source, " causing thereby an economy of many thousand pounds. " 6. Among the expenses of the Caledonian canal there was " a sum of $£ 47,956$ paid for the acquisition of the grounds " occupied. In the Isthmus those which are not lay or waste " lands, and therefore the only portions that do not belong by " right to the Projector, are in their present state insignifi" cant as to their value : and $\mathbf{l}$ will only say that if it were de"sirable to turn into a lake the valleys of Chicapa, Monetza, " and even that of the village of San Miguel itself, the amount " of indemnifications to be paid would be considerably under " any supposition that might be made in Europe, however un" derrated it might appear.

" From all the circumstances just mentioned, and from the " knowledge I have of the localities, I am authorised to infer " that the preceding estimate may be considerably modified, " and the valuable produce of the country which from this " moment might be turned to account, would procure annu" ally no small portion of the funds requisite for the work. "Neither would it be necessary to wait until its completion to 
" establish a commercial communication between the two " oceans; for the river Coatzacoalcos might soon be made na"vigable and the Boca Barra of San Francisco fitted for im" mediate use."

"A lateral line of rails for the conveyance of mails, pas" sengers and merchandise might also be added to that which " must at first be laid down for the progress of the work." 


\section{CHAP. IX.}

ESTIMATE OF RETURNS.

The Isthmus the nearest unoccupied tropical country to Europe-The nearest and safest route to the Pacific and Chinese Seas-The voyages to the West Coast of America shortened by 6,500 to 12,000 miles.-Enumeration of the products of the Isthmus.-Grants of Land and privileges of Colonists.-Steam Navigation and CoalsSalt-Free-labourers.-Commercial movement round Capes Horn and Good Hope.-Transit dues-Sales of Land: and Steam Navigation-Dye-woods, timber, and fine woods-Value of other articles -Total annual receipts on the completion of the communication calculated at $£ 1,200,000$.-Extract from a Report made to the Congress of the United States in 1839.

'The territory of Tehuantepec, from its position, its population, and its produce, offers peculiar facilities for the opening of the Isthmus.

The advantages, which would result from the opening of the Isthmus, are so numerous and considerable, that it would be impossible to name the total amount of the returns which might be realised; but it would not be difficult to prove that even were we to adopt for our calculations only a limited number of those advantages, the value of which is incontrovertible, the result would exceed in the most extravagant degree that of any other speculation, even those generally considered as the most profitable.

1st. It is the nearest country to Europe, yet unoccupied to any great extent, yielding every tropical produce.

2nd. It is universally admitted that in consequence of the favourable direction of the winds and currents, ships proceeding from Europe to China, the Phillipine Islands, and the 
great Pacific Ocean, through the Isthmus, would perform the voyage in a much shorter period than those following the present track by the Cape of Good Hope, and it is equally well known that this voyage would be performed through regions always exempt from dangers, and at all times of the year, which is scarcely practicable round the Capes. Its local resources would enable ships to renew their provisions halfway to the Indian Seas, and thus allow them to take on board a greater quantity of merchandise.

3rd. Ships from Europe, bound to the north-western coast of America, would save a distance of nearly 6,500 miles, and those of the United States from 9,000 to 12,000. And the coasts of the Oregon territory, the Californias, Mexico, Peru, and Chili, that is, an extent of nearly eight thousand miles, from Nootka Bay to Cape Horn, would receive a new existence, and be easily accessible to the superabundant population of all the world.

4th. The cerealia which those countries can produce, the hides, fish oil and whalebone, cotton, indigo, sugar, coffee, cocoa, cochineal, sae-morse ivory, rich furs, precious metals, \&c. present so many branches to the speculator. And the spontaneous products of the Isthmus, are wax, silk, caoutchouc, pepper, sarsaparilla, vanilla, gums, and resins, tortoise-shell, coral and pearls. But among all these productions, the timber of its immense forests deserves particular mention. Its abundance is such, that the only limit which can be assigned to the supply it may yield is the demand for centuries to come. From the fir, the oak, the cedar, and every description of building timber, to the dye and fine woods, their profusion is absolutely incredible. None of the countries which at present supply these species of woods could compete with the Isthmus, where they are found on the very banks of the rivers which serve for their transport.

5th. The territories, assigned to the Projector in fee simple by the Mexican government, occupy an extent of 56 Mexican leagues in length by 20 in width; that is, 1,120 square leagues, each containing 4,310 acres, thus making a total amount of nearly five millions of acres. This with the right of making settlements within 50 leagues on either hand of the cominuni- 
cation (also comprised in the grants) presents an opportunity of establishing one of the noblest Colonies the Civilized world has ever yet witnessed.

6th. Steam navigation through the Isthmus is an exclusive privilege of the enterprise during sixty years. The quantity of coals existing in the Republic, and the facility with which they might be conveyed to the Isthmus, would offer also considerable advantages to all vessels proceeding through the Isthmus.

7th. Salt pits are extremely abundant, which might be turned to profitable account without any other outlay than the bare expenses of conveyance. The N. W. Coast of America receives at present its supply from the United States by way of Cape Horn. Salt might be sent to the countries in the neighbourhood of the line of communication, such as Chiapas and Guatemala; as well as to the Havannah and New Orleans, where the price generally averages eight or ten dollars per ton.

Lastly, the country itself can supply thousands of workmen at moderate wages, all free labourers, for there is not a single slave in all the Republic of Mexico.

From the consideration of these favourable circumstances just enumerated, it is fairly presumable that the communication, once opened would be adopted by nearly the whole of the vessels which at present double the two Capes.

A most careful investigation shews that there left the ports of Great Britain, during the year 1843,

\section{To double the Cape of Good Hope,}

417 vessels of the aggregate burden of 164,447 tons.

To double Cape Horn,

300 vessels, of the aggregate burden of 110,040 tons.

which, supposing the number of arrivals to equal that of departures, gives a total amount of

$$
\text { 1,434 vessels . . and . . 548,974 tons. }
$$

This amount agrees with the results given in the Documens sur le Commerce exterieur, published by the minister of com- 
merce of France, and according to which, including only the four principal maritime powers, namely, England, France, the United States, and the Netherlands, the movement out and home was

$$
\begin{aligned}
& \text { In } 1839 \text {. } 2,453 \text { vessels . . . . } 983,890 \text { tons. } \\
& 1840 \text {. } 2,532 \text {. . . . . } 1,000,995 \\
& 1841 \text { • . } 2,996 \text {. . . . . . 1,203,762 }
\end{aligned}
$$

The changes, which have taken place in the mutual relations of Europe and China, must have considerably increased these numbers, and there is no doubt that the amount of tonnage conveyed by these four nations alone, exceeds at present one million and a half. To this amount must be added the navigation of the other maritime powers.

After what has been said, it is no exaggeration to suppose that, in consequence of the opening of the Isthmus, the commercial movement would soon reach two millions of tons. Let it however be calculated that only three-fourths of that traffic passes through the new channel, namely one million and a half.

1. By exacting from the vessels the moderate transit duty of 2 dollars per ton, the million and a half would yield a sum of $£ 600,000$.

2. The sale of lands, and the privilege of steam-boats, may yield (say only) $£ 50,000$. Lands analogous to that of the Isthmus but less advantageously situated, would be worth in Cuba more than $£ 2,000$ per square league.

3. The consumption of dyewoods, mahogany and other fine woods, such as the Isthmus can supply, amounts, for London and Liverpool alone, to upwards of sixty thousand tons, the value of which, at the present market prices, exceeds $£ 300,000$ nett of all charges, and when the demands of every other country are taken into account, it is but reasonable to put down under this head the sum of $£ 500,000$.

4. We will give to the other produce a value of only $£ 50,000$ nett, although it is evident that such a sum is considerably below the real valuation; indeed, from what is said on the subject in Sr. Moro's Report, it may be inferred that the article pepper alone would yield $£ 10,000$; the gums and resins more 


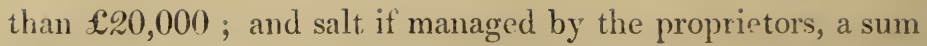
equal to the latter. 'The immense quantity of vanilla which might be collected is of great value; and a considerable fishery, including that of tortoise-shell and pearls, would give results no less surprising. Lastly, we count for nothing what might be derived from the mines which must exist in the mountains of the Isthmus, since they are only a continuation of the rich chain of Oajaca.

Adding together these sums, we have,

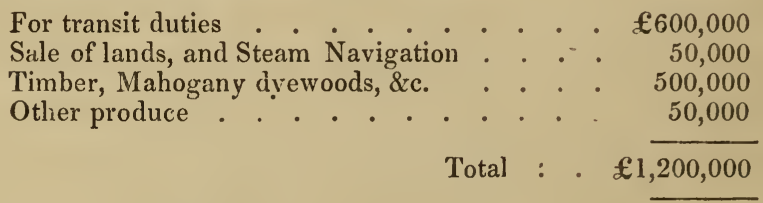

Calculated receipt when the canal shall have been completed, subject only to the annual expenses of management and repairs of the canal, and the nett one-fourth of the transit dues payable to the Mexican government.

We cannot now better conclude this subject than by giving the following extract from a Report made in the year 1839 to the congress of the United States, shewing of what immense importance the opening of any ship Canal across the American Isthmus would be considered in that country; and we give this verbatim as Sr. Moro has inserted it in his work. In the United States, where the advantages offered by such a project are generally better understood than anywhere else, its probably results have been very carefully investigated and studied; and in the Report, No. 332, presented in 1839, during the third sessions of the twenty-fifth Congress, we find, at pages 111 and 112, some very remarkable observations. The author, formerly consul of the republic at Lima, supposes the opening of the Isthmus (without fixing upon any particular locality) to cost twenty millions of dollars, or $£ 4,000,000$ sterling; and upon this basis he reasons in the following manner :-

"Suppose the work to cost twenty millions of dollars, the " interest thereon, at four per cent. per annum, would be 
" eight hundred thousand dollars annually. But in order to " present sufficient inducement to advance the capital re"quired, and suitably to reward contributors to an object so " beneficial to the world, a higher compensation ought to be " allowed, and, as far as possible, to be guaranteed; limited, " however, from considerations of general equity and policy, " to a rate that would not be extravagant. Without assigning, " at present, more particular reasons, it will be assumed that " the rate of interest should be about double the usual value " of money; that is, about eight per cent. per annum on the " capital invested, and never allowed to exceed that rate; " payable half yearly from the period when the income of the "canal shall be sufficient to meet it, with an accumulation " on the advances of four per cent. per annum until that " period arrives. This would require a revenue from the canal " of one million six hundred thousand dollars annually.

"It is easy to show how that amount, and a great deal more, " would be produced, or rather would be saved, by means of " the canal, upon the present commerce of the world that " would flow through it, whenever opened, without calculating " its certain and almost unlimited increase, and consequent " larger savings in time.

" The mere difference in the amount of insurance paid, the " interest of money invested, and the expenses of navigating "vessels employed between voyages from the United States " and Europe to the Pacific Ocean, and all the countries " bordering on it, by way of the canal, or by Cape Horn and " the Cape of Good Hope, would far exceed annually the one " million six hundred thousand dcllars required for interest on " the cost of the canal. But it is impossible to make esti" mates, from present information, more precise or accurate " than as approximations towards correctness, of which the " following is a specimen ; viz., " The average length of voyages from the United States " round Cape Horn to the principal ports on the west side "of America, and to the whaling districts of the Pacific is " above four months; while, by way of the canal, it would not " exceeed one month, making a difference of three months G 2 
" each way, and six months on a voyage out and home, usually " performed in about a year, except by whaling vessels; con" sequently there would be a saving effected of insurance on "vessels and cargoes, and of interest in the amount of their " cost, and of expense in navigating those vessels, just in pro"portion to the saving of time on the royages. This saving " would be about one-half, or one per cent. both on the in" surance and on the interest, as is usually paid, and conside" rably more on the expenses of navigation, making not less " than ten per cent. per annum. It is estimated there are at " least one hundred ships or vessels of the United States sail" ing annually from home ports for the Pacific, and as many " returning thence, including those employed in whaling; the " aggregate value of all which, with their cargoes, may be esti" mated as high as five or six millions of dollars, and ten per " cent. saved thereon would be at least half a million of " dollars.

"The British and Europeans exchange annually with the " western side of America to a much larger amount, and carry " on also considerable whaling business in the Pacific. As, "from the relative distances, the time to be saved in their " voyages would be rather less than those from the United "States, and the saving of insurance, interest, and navigating " expenses, of course proportionally less, yet, as the amount " of their exchanges is so much larger than ours, it may be " about correct to estimate the whole saving on the trade of "Europe with the Pacific through the canal as at least equal " to that on the trade of the United States through it-viz., " half a million of dollars-making together, therefore, at least " one million annually. In addition to this must be estimated " the saving on the whole trade of the United States and of "Europe with China and the neighbouring countries and " islands of the Pacific, which would be carried on by way of " the canal, because that route would be above four thousand " miles shorter than by the Cape of Good Hope, without " crossing the equator or reaching high latitudes, and would " reduce the length of voyages out and home at least two " months on an average; consequently as much as three per 
" cent., if not more, on the aggregate amount of that trade " must also be estimated as to be saved by the canal : but the " amount of that trade is almost incalculable. "From official reports to Congress it appears that the ex" changes between the United States and Canton alone amount " to above ten millions of dollars annually. Those between " Europe and China and neighbouring countries must be a vast " deal more, perhaps four or five times as much; but suppose " only a little above twice as much, and that the whole amount of " exchanges of both Europe and the United States with China " and the neighbouring countries was only thirty-three millions " and a third of dollars, then the saving thereon by means of " the canal would be as much as one million of dollars annually, " thus making altogether two millions. "Thus it appears that if the present commerce of the United "States and of Europe with the western side of America, the " islands of the Pacific and China and neighbouring countries, " should be carried on through the canal, the immediate " annual saving thereon, upon the ground stated, without re"ference to other great benefits, would not be less than two " millions of dollars (and it might be a great deal more), while " the whole revenue required to pay the interest of the cost of " the canal, at the high rate of eight per cent., would be only " one million six hundred thousand dollars; consequently " there can be no doubt of sufficient remuneration for the " capital to be employed. But this calculation does not com" prehend all the sources of revenue to be derived from the " canal: it merely shows the saving to be made in effecting " the present exchanges between certain parts of the world by " means of the canal, and the amount which might, of course, " be levied for the use of the canal, without adding at all to " the present charges on the same commerce. Other advan" tages would justify additional charges if more income were " required; but the natural growth of commerce, together " with that resulting from the increase of facilities, would soon " produce an immense addition and a vast surplus of income " from the canal, unless limited by previous restrictions, as " proposed, and as it ought certainly to be." 


\section{A P P ENDIX.}

Memorial of Don José Garay, soliciting of His Excellency the President of the Mexican Republic, the privilege of opening a Communication between the Atlantic and Pacific Oceans, through the Isthmus of Tehuantepec.

SIR,

Your Excellency has caused the Mexican public to look forward to the present epoch as one of improvement and gigantic advancement in the career of national aggrandizement.

No measure can be more fruitful in prosperous results, - none more remarkable or more glorious than that which shall form a junction between the two oceans, without the necessity of doubling that stormy cape, discovered by a Hollander, and to which he gave his name, which forms the Southernmost extremity of the American Continent.

Thousands of ships yearly perform this difficult and tedious voyage, passing twice through the tropics in the midst of innumerable and imminent dangers.

The mind is bewildered with the difficulty of embracing in one comprehensive view, the astonishing consequences that would result from a communication between the two oceans, by means of which ships sailing from Europe will save two thousand leagues, and those from North America, three thousand one hundred leagues, in their voyage to the coast of China. What an economy of time and money! And how far will these advantages extend now that the lines of Steam Boats established upon the high seas have so prodigiously shortened distances !

A great revolution will take place in the commercial and even in the political affairs of all nations, the instant America shall open the passage through any of her Isthmuses. The epoch which shall see this effected will be more memorable than that of the discovery of this Continent; and the name of him to whom the world shall owe this event will be at least as glorious as that of Columbus.

If your Excellency is ambitious of this glory for yourself and your Country 


\section{3}

you should now dedicate your attention and the powerful mind with which you are endowed to the execution of the Enterprise contained in the present representation and to which is annexed the project I have conceived for forming a communication between the two oceans.

By this your Excellency will see that I propose to execute this gigantic work in a very short time, considering the magnitude of the Enterprise; and I ask not the least pecuniary assistance from Government, and from the commencement, 1 offer to the National Treasury, a considerable revenue, viz. one fourth of the transit duties on the line of the route; and these will, after the term of fifty years, belong wholly to the Republic.

What I ask as an indemnification of expenses is certainly not much, when it is considered that it will be necessary to form forts, raise fortifications, and other edifices, and open roads or canals ; and when it is borne in mind that the indemnification does not consist in any funds of which the government is at present possessed, but in property to which I am about to create a value.

The value hereafter of the lands of which I solicit a grant, will be the consequence of my efforts, for at the present day they have none whatever.

The enterprise could not be undertaken by any person for less than what $I$ have solicited, because the magnitude of the works will be such as probably to absorb all the resources arising from what I ask.

Your Excellency cannot fail to remark two very striking features in my project. First : the establishment of the neutrality of the line of transit-this is a point worthy of the magnanimity of government, and necessary to interest all nations; in order that the communication may not be seized by any foreign power, but be ever preserved as the property of the Republic. Secondly: that I have not proposed to open immediately a Ship Canal across the Isthmus; because I have seen similar proposals fall to the ground in other parts of Central America and Columbia: Often the desire of carrying into execution a magnificent undertaking is the cause why a lesser one though highly important, has been neglected.

Convinced that it has been well said that by "seeking perfection we lose what may be attainable," I have resolved to carry the latter into effect, without however renouncing my hopes of accomplishing the former; although a communication by water may not be practicable for the present, this will infallibly take place when the Isthmus shall become known from the commerce of the world traversing it, when the advantage of giving to this grand work all the perfection of which it is capable shall be duly appreciated, and when both sides of the line shall be dotted with rich and populous cities, as will certainly happen in a fe:v years.

Let this be enumerated among the acts of your Excellency's public life, and your name will not only belong to the glory of your Country, but will be identified with the best interests of mankind, and immortalized by an imperishable monument. The whole world will receive incalculable benefits; and what advantages will not accrue to Mexico in particular, when the accomplishment of this undertaking shall make her the centre of universal commerce giving a vast impulse to the elements of her terrestial wealth undeveloped at present from the little intercourse she enjoys with the splendour and industry of Europe? 


\section{4}

I beg leave, Sir, to repeat that the mind is bewildered in the attempt to calculate the beneficial results that must accrue to Mexico from the facility with which her native products will be exported ; and from her becoming the Emporium of the Commerce of the world; as also from deriving revenues from duties not levied upon the inhabitants of the Republic, and from the vast influx of population and capital into the country.

May your Excellency, therefore, become the Author of these great and numerous benefits to your country, and by acceding to the articles of this Memorial, thus sauction the most memorable act of your illustrious and patriotic career.

Mexico, February 25, 1842,

José de Garay.

No. 2.

Edict ordering the opening of the Isthmus, with the Grants therein specified; and Contract between the Supreme Government and Don José de Garay.

"Antonio Lopez de Santa Anna, General of Division, Benemerito of t!e Country, and Provisional President of the Republic of Mexico, to all the inhabitants, thereof, Know ye :

That firm to my purpose of exalting the nation and of rendering the people happy; and taking into consideration the propositions which Don José Garay has presented, and considering that no means are so sure and effectual for promoting the national prosperity as that of creating the Republic the centre of the commerce and navigation of all countries ; and that this must be the consequence of the establishment of an easy and short communication from one ocean to the other:-That nature itself offers the means of accomplishing this, without opposing any great obstacle, and without the necessity of incurring any vast expense, in the Isthmus of Tehuantepec; inasmuch as there the Cordillera dips to such a degree that it may almost be said to disappear; that there are two harbours in those parts, one towards the north and the other towards the south, at a short distance from each other, and that a considerable portion of the space between them is transitable by means of a navigable river and a lake, and that the nature of the intermediate ground is favourable for carrying on such works as it may be necessary to undertake, as it abounds in materials for construction:-And considering that if up to this moment public attention has not been properly called to this enterprise (which alone is capable of exalting the Republic), this has, perhaps, happened from not having duly calculated its important consequences, or because the possibility of its execution has not been 


\section{5}

known, or that from a preconceived idea existing in favour of making a cut to join the two oceans, the advantages of a road or canal destined for the transhipment of goods has been entirely lost sight of, by which the same results might be approximately obtained :-And furthermore desiring, if more cannot be done, to accomplish what is practicable, but still of the greatest importance to the Republic and to the world in general; and seeking, by promoting the execution of what is at present attainable, to give an impulse to future attempts on a larger scale, sirce the opening of a line of "communication, by tending to show that it is not difficult to cut across the cortinent, may hereafter conduce to the undertaking of this great work:-Feeling, besides, that in order to encourage the spirit of speculation, it is necessary to make concessions, by which alone enteprise has ever been fostered; and that by this enterprise in particular the nation will obtain revenues with which it cannot reckon at present, derivable from foreign trade, and immediately reap the advantages which must result from universal intercourse, when its soil shall become the emporium of commerce, and consequently teem with wealth and abundance, when its various products sl all become articles of exportation:-Therefore, by virtue of the powers and faculties vested in me by the 7 th article of the convention signed at Tacubaya and sworn to by the Representatives of the Departments, I have determined to issue the following

\section{DECREE.}

Article 1. A line of communication shall be opened between the Pacific and Atlantic Oceans through the Isthmus of Tehuantepec.

Article 2. This shall be performed by water, but when this may not be convenient, then railroads and steam carriages may be used.

Aiticle 3. The passage to be opened across the Isthmus, shall be neutral, and common to all nations at peace with the Mexican Republic.

Article 4. The execution of this work shall be confided to Don Jose Garay ; to whom is hereby granted an exclusive privilege to this effect. His obligations and indemnificaticns shall be as hereafter expressed :-

First. Don José Garay shall cause to be made at his own expense a survey of the ground and direction which the route should follow ; and also of the ports which may be deemed most proper and commodious from their proximity; all which shall be concluded at furthest within the space of eighteen months from the date hereof: and the works shall be commenced at furthest within the space of ten months next thereafter; - and in case this shall not be performed within the time specified, the exclusive privilege hereby conceded to him shall cease.

Second. The said Don José Garay shall cause to be made in the ports which he shall select, all kinds of works that may be necessary for shelter and utility. He shall construct in each of them fortresses and warehouses; he sliall carry into effect the line' of communication between the two ports by means of watercarriage or railroads, in both cases by means of steam ; and he shall establish as many steam-boats and trains of steam-cars as shall be deemed necessary, so that there shall be no delay for want of means of transport.

Third. The grantee shall pay at a just valuation for any private property 
through which the route shall pass; but he shall not demand on account of public utility, more than a quarter of a league on either side of the line, which is all he can require the proprietors to sell.

Fourth. The indemnifications which are here accorded to the grantee and to those who may acquire his rights, are the following:- $\mathrm{He}$ shall have the right of collecting the transit duties for the term of fifty years, at the expiry of which time they shall revert to the Government of the Republic; and for sixty years the exclusive privilege of carrying on the transport by steam-vessels and railroad cars, fixing equitable rates of freight. But he shall give to the Government, from the time that the line of communication sliall be made available, the fourth part of the nett produce of the dues that are paid for the right of transit, deducting all expenses of administration, preservaticn, and repairs. A similar fourth part shall be given by the Government to the Negotiation for a like term, when it shall enter into possession of the before mentioned transit dues, payable on the line of communication.

Fifth. The Government and the Negotiation may each name their agents to look in to the receipts and expenditures, during the whole of the time that each resfectively shall be entitled to the before mentioned fourth part of the transit dues. All the unoccupied lands for a distance of ten leagues on either side of the line of communication, road or canal; are hereby ceded in fee-simple to the Negotiation.

Sixth. All foreigners are permitted to acquire real property, and to exercise any trade or calling, not even exceptir $g$ that of mining, within the distance of fifty leagues on either side of the line of transit. That territory shall be the country of all who may come to establish themselves there; subject, however, to the laws of the Republic.

Seventh. The Government engages to give to the Negotiation cvery protection and assistance, as well for effecting the survey as for carrying on the works ; but th remuneration of the services of the inhabitants of those parts shall be at the expense of the Negotiation. The Government also engages not to impose any contributions or taxes upon the travellers or effects in transitu, during the aforesaid term of fifty years, and not to levy upon the Negotiation or its finds any imposts or forced loans.

Eighth. The Government shall have the right of appointing the customhot:se officers which it may see fit, in the ports and in any other points it may choose, on the line of communication : but only for the purpose cf recovering the duties of exportation and importation upon articles which do not come and go merely in transitu, and for the prevention of smuggling. The Government shall in no case interfere in the collection of transit dues, nor in the collection of freights, lighterage or tonnage, or of any other class of dues, for none shall be payable by vessels loading or unloading in transit, as long as the line of communication sball belong to the Negotiation. The measures which the Government shall adopt for the prevention of smuggling, shall be such as to cause no embarrassment or delay in the transport of effects across the Isthmus, and particular regulations will be adopted and issued to this effect.

Ninth. When the works shall be completed, they shall be examined by two surveyors, one to be named by the Government, and the other by the Negotia- 
tion, in order that they may declare whether the terms of the contract have been complied with by the latter; and in case these shall disagree, the surveyors shall nominate an umpire who shall settle the dispute. No kind of question or difference shall prevent the line of communication from coming into operation as soon as it shall be ready; nevertheless the Negotiation is always bound to fulfil the contract in every particular.

Tenth. In case it should hereafter be found practicable to join the two seas by a cut, and that propositions to this effeet should be made by any individual or any company, they shall not be admitted during the period of fifty years for which the privilege is granted to Don Jose Garay, without his previous consent or that of those who may have acquired his rights.

Eleventh. The contract between the Government and Don José Garay shall be drawn out in writing according to the tenor of the articles forming the basis of this decree, with all the f,rm lities required by the law.

Therefore I command that it be printed, published and circulated, and duly carried into effect. Given at the palace of the National Government this 1st day of Marci, 1842.-Antcnio Lopez de Santa Anna.=Jose Maria Bocanegra.

\section{No. 3.}

Decree by which the Government declares that all the lands granted previous to the decree of the 1 st, of March, both to natives and foreigners, and which are neither tenanted nor cultivated, belong to Don José Garay.

Office of Foreign Affairs.

To their Excellencies the Governors of Oajaca and Vera Cruz.

[Copy.]-His Excellency the Provisional President has been pleased to publish the following decree:

Nicholas Bravo, General of Division, Benemeritus of the country, and provisional President of the Republic of Mexico, to all the inhabitants be it known :-That a grant having been made in favour of the undertaking to open a communication between the two oceans, through the Isthmus of Tehuantepec, of the untenanted lands lying within ten leagues on both sides of the line of communication, which according to the surveys already made must pass througb the river Coatzacoalcos, and wishing to remove every obstacle which might prevent or retard the realization of the undertaking, I have deemed it necessary in right of the faculties which the 7 th article of the Convention signed at Tacubaya, and sworn to by the representatives of the various departments, awards to the Supreme Government, to declate the following : 
All the grants of land made either to natives or to foreigners previous to the decree of the 1st of March, 1842, from among the untenanted lands mentioned in the 3rd article of the said decree, and which actually remain uninhabited and uncultivated, are comprehended in the concessions made in behalf of the undertaking for the communication of the two seas, therefore I do order this to be printed, published, and circulated for the purpose of being fulfilled.

Palace of the Government, Mexico, Febuary 9th, 1843.

Nicholas Bravo.

J. M. De Bocanegra, Minister for Foreign Affairs.

A true copy of the original document transmitted to the Governors of Vera Cruz and Oajaca, which I enclose to you for your intelligence.

God and Liberty, Mexico, February 9th, 1843.

O. Monasterio.

No. 4.

Communication from Don José de Garay to his Excellency the Minister for Foreign Affairs, enclosing a letter from the Secretary of the Commission of Survey, announcing his return to the capital, and repeating the opinion already expressed by him on the possibility of opening the intended communication through the Isthmus.

Office of Foreign Affairs.

\section{Most Excellent Sir;}

In a letter of the 18th instant the Secretary of the Commission of Survey writes as follows: "I arrived here yesterday with the Commission, who last year left this capital to explore the Isthmus of Tehuantepec for the purpose of opening a communication between the two oceans, according to the decree of the 1st of March, 1842. My former note informed you of the favourable results of our labours in that part of the country, and nothing could be more gratifying to me than to repeat my opinion concerning the practicability of the undertaking, which will be ever memorable from the great good and the important changes it will effect in the destinies of the Republic. The Commission will now proceed to arrange the notes, observations, and plans, in which will be shown the project they have conceived, and they hope to discharge this part of their duty with all the exactness the great importance of the enterprise demands. It remains now for me to assure you that the chief engineer, Don Cayetano Moro, and Captains Don Manuel Robles and Don José Gonzalez, are worthy of the highest esteem for the indefatigable activity and zeal with which they applied their scientific acquirements to the attainment of our object; and the third member of the 
Commission, the navy officer, Don Mauro Guido, is no less praiseworthy for his kind disposition and constant attention to every charge committed to his care. Finally I beg to express my gratitude for the confidence placed in me when entrusted with this Commission, and to assure you that $I$ have sought by every means in my power to justify your choice."

In enclosing this to your excellency, that you may convey it to the knowledge of his Excellency the President, I deem it my duty to call his attention to the merit and zeal displayed in the fulfilment of his Office by the firit naval officer, Don Pedro de Garay y Garay, Secretary to the Commission, whose ability, zeal, and devotedness are worthy of commendation. I have the honor to repeat to your Excellency my professions of respect.

God and Liberty, Mexico, April 22, 1843.

José de Garay.

To his Excellency the Minister for Foreign Affairs.

\section{Answer of his Excellency the Minister for Foreign Affairs, to the above communication.}

His Excellency the Provisional President of the Republic was much pleased with the persual of your note of the $22 \mathrm{~d}$ inst., in which you enclose that of the Secretary of the Commission of Survey, containing a reiteration of his opinion that it was possible to open a canal between the two oceans through the Isthmus of Tehuantepec. His Excellency waits for the documents you have offered, in order to obtain a clearer idea of the investigation which has been concluded and of the great result we may anticipate from it.

I beg to reassure you of my consideration.

God and Liberty, Mexico, April 29th, 184.

Senor Don José de Garay.

Bocanegra.

No. 5 .

Decree granting to Don José de Garay the term of a year, according to his request, for the commencement of the worls.

Sir,

Office of Foreign Affairs.

His Excellency the President ad interim, whom I acquainted with your request, that the period prescribed in the decree of March 1842 for the 
commencement of the works in the Isthmus of Tehuantepec should be postponed for the term of a year, has been pleased to determine in Council this day that the same shall be granted.

God and Liberty, Mexico, December 28, 1843.

BOCANEGRA.

Senor Don José de Garay. 


\section{A.}

\section{ASTRONOMICAL OBSERVATIONS.}

\section{TABLE No. 1.}

Latitudes determined from astronomical observations.

Cupola of the church of Juchitan . . . . . . $16^{\circ} 26^{\prime} 10^{\prime \prime}$

$\begin{array}{llllll}\text { Church of San Mateo Huazontlan del mar . . . . } & 16 & 12 & 47\end{array}$

Id. San Dionisio Tepehuazontlan . . . . 161630

Id. San Juan Guichicovi _ . . . . . $\quad \begin{array}{llll}16 & 58 & 35\end{array}$

Id. Santa Maria Chimalapa . . . . . $\quad \begin{array}{lllll} & 16 & 55 & 5\end{array}$

Paso de la Puerta . . . . . . . . 171235

The strand on the right bank of the Coatzacoalcos below the mouth of the river de la Puerta (or Jumuapa) . $\quad$. $\quad \begin{array}{llll}17 & 21 & 5\end{array}$ South point of the island of Pedernal . . . . . $\quad . \quad \begin{array}{llll}17 & 27 & 45\end{array}$

Horqueta of the island of Tacamichapa - . . . 1743 ",

Hidalgo-titlan . . . . . . . . . . 174636

$\begin{array}{llllllllllll}\text { Mina-titlan } & 0 & 0 & 0 & 0 & 0 & 0 & 0 & 55\end{array}$

Mouth of the Coatzacoalcos Long. W. of Greenwich $94^{\circ} \quad 17^{\prime} 0^{\prime \prime}$ Lat. $18 \quad 8 \quad 30$

Bocabarra

$\begin{array}{llllll}94 & 53 & 22 & 16 & 13 & \end{array}$

\section{TABLE No. 2.}

Geographical positions of the principal points of the Triangulation.

The longitudes rcckoned from the meridian of Juchitan, which is $95^{\circ} 9^{\prime} 37,5^{\prime \prime}$ west of Greenwich.

$$
\text { North West }
$$

Latitudes. Longitudes.

\begin{tabular}{|c|c|c|c|c|c|c|c|c|c|c|c|c|}
\hline Cerro del M & & • & & & & • & & $16^{\circ}$ & $10^{\prime}$ & $24^{\prime \prime}$ & $7^{\prime}$ & $57^{\prime \prime}$ \\
\hline Xunirahui & - & • & . & - & & - & & 16 & 12 & 40 & 13 & 10 \\
\hline Daniguibixo & . & . & . & . & & . & & 16 & 14 & 36 & 7 & 16,5 \\
\hline Town of $\mathrm{Hu}$ & tepec & - & . & . & & . & & 16 & 14 & 54 & 7 & 42 \\
\hline Daniliesa (C & ro de & & eva) & & & . & & 16 & 20 & 7 & 13 & 16 \\
\hline
\end{tabular}




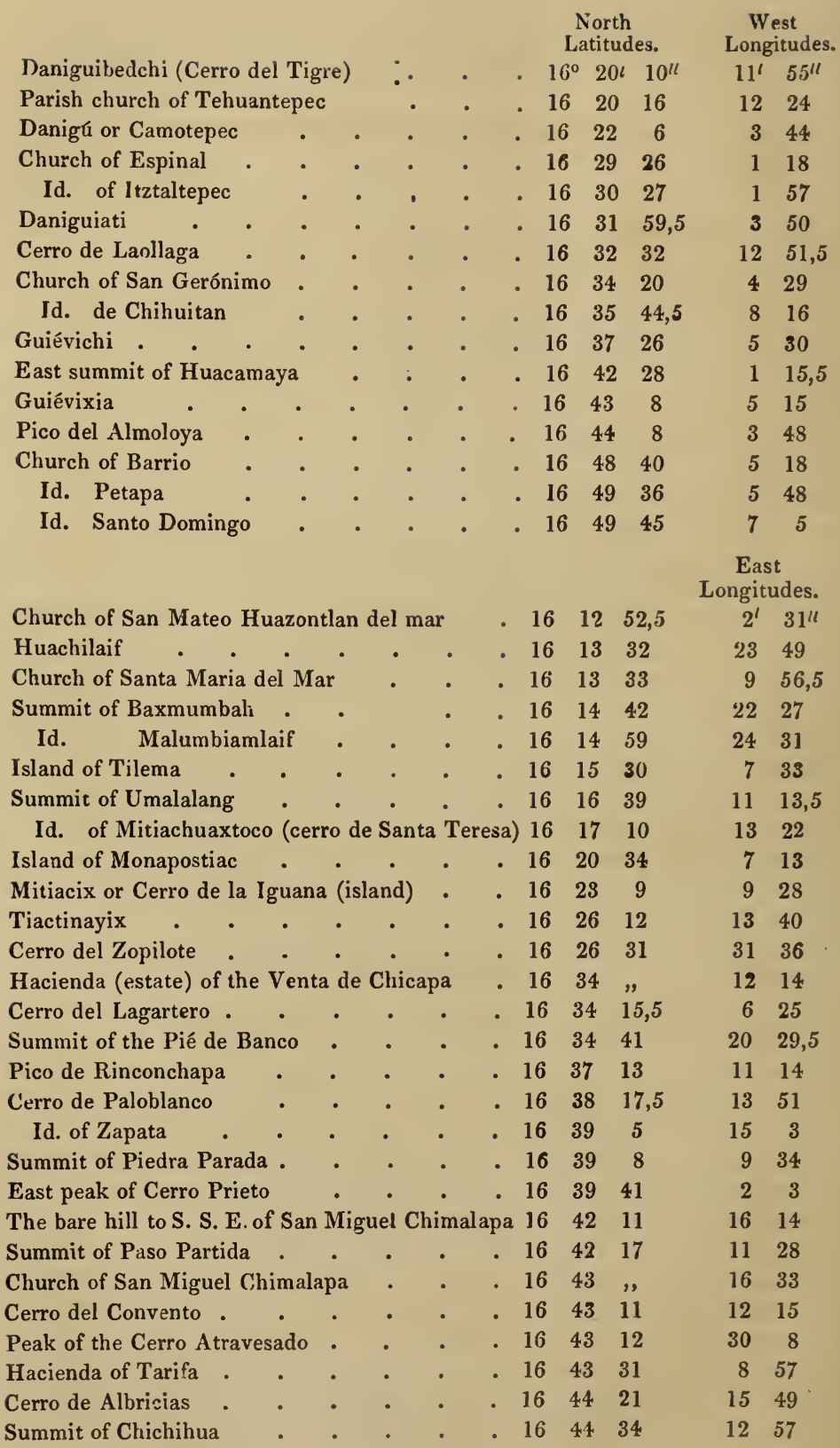


TABLE No. 3.

Altitudes resulting from trigonometrical measurements.

Heights above the level of the sea.

Summit of Daniguiati metres 274,5

Top of the cupola of the church of Juchitan a $\quad$. $\quad 35,8$

Basement of the same church . . . . . . 18

Monapostiac . . . . . . . . . . 111

Umalalang : • • • • . • • . • 218

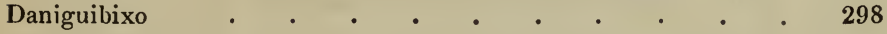

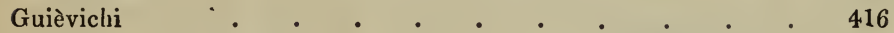

East peak of Cerro Prieto . . . . . . . . 460

Guiévixia . • . . . . . . . 598

Masahua (the middle summit) . . . . . . . 687

East summit of Huacamaya $\quad$ • . . . . . . . 775

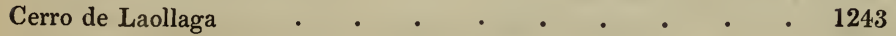

Palo Blanco . . . . . . . . . . 371

Estate of Tarifa (the place of the habitations) . . . $\quad 208,5$

Cerro de Piedra Parada . . . . . . . . 4 4I6

Id. del Convento . . . . . . . . . 446

Paso Partida . . . . . . . . . . . 466

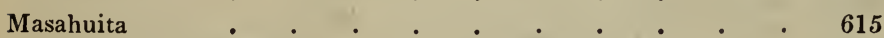

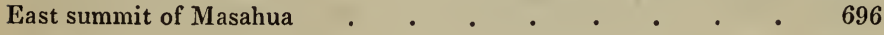

Guiéxila $. \quad . \quad . \quad . \quad . \quad . \quad . \quad . \quad . \quad . \quad .1152$

Peak of the Cerro Atravesado . . . . . . . 1529

The highest peak beyond it . . . . . . 2343

TABLE No. 4.

\section{BAROMETRICAL ALTITUDES}

Across the Isthmus of Tehuantepec.

Heights above the level of the sea.

Umalalang . • . • . . . . . metres 220

Mitiachuaxtoco $. \quad . \quad . \quad . \quad . \quad . \quad . \quad . \quad .250$

Daniguibixo . . . . . . . . . . $\quad$. 296

Venta de Chicapa (house at the estate) . . . . . . 24

The river Chicapa, near the Rancho of la Puerta Vieja . . 83

The river Coatzacoalcos at the confluence of the Chimalapilla $\quad 119$

Source of the stream Monetza . • • • . . . 196

Petapa (the town house) . . . . . . . . 204

The river Chicapa at the Ultimo Rancho . . . . . 208 
Heights above the level of the sea.

Farm of Chivela . . . . . . . metres 210

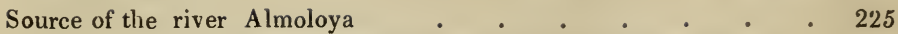

Santo Domingo (the town-house) . . . . . . $\quad$. 226

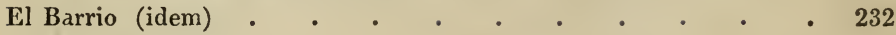

Road from Santa Maria to San Miguel Chimalapa.

San Miguel Chimalapa (the town house) . . . . metres 119

Rancho de la Cofradia . . . . . . . . 376

Tbe stream running towards Chichihua and often traversed 275

Jacál del Ocotal . . . . . . . . • • 331

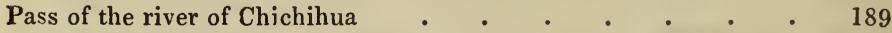

Pass of the river Escolapa . . . . . . . . 50

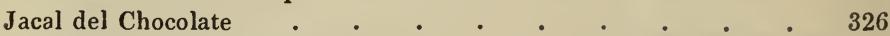

Pass of the rivers del Milagro $\quad$. $\quad$. $\quad . \quad . \quad . \quad .84$

Santa Maria Chimalapa (the town house) • • • • • 262

La Piedra del Viejo (the highest point between Santa Maria and the river) . . . . • . . . . . 296

The river del Corte at the confluence with the Chimalapilla $\quad 119$

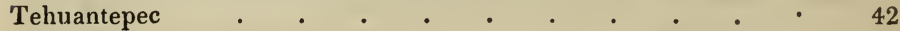

Zanatepec . . . . . . . . . . . 50

San Gabriel Boca de Monte . . . . . . 50

San Juan Guichicovi (the town house) . . . $\quad 249$

TABLE No. 5 .

Heights above the level of the sea of various places on the road

from Tehuantepec to Puebla.

Tequisistlan . . . . . . . . metres 210

Rancho de las Vacas . . . . . . . . $\quad$. 745

San Bartolo Yautepec. . . . . . . . . . . 870

Rancho Quemado . . . . . . . . . 1160

San Pedro Totolapan (the lowest part of the town) . . . $\quad$. 940

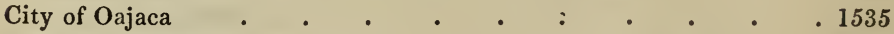

San Juan del Estado.$\quad$. $\quad . \quad$. $\quad$. $\quad$ : . 1680

Venta de Aragon . . . . . . . . . . . 1005

Cuicatlan . . . . . . . . . . . . 420

City of Tehuacan . . . . . . . . . . . 1575

Tlacotepee . . . . . . . . . . . 1905

Tepeaca . . . . . . . . . . . . 2210 


\section{B. \\ GE 0 L 0 G Y.}

Catalogue of the Geological Collection formed in the 1sthmus of Tehuantepec by the scientific Commission entrusted with the exploration of the Isthmus, and classified by Senor Don Andres a'el Rio.

\section{SIERRA MADRE (PRINCIPAL CHAIN) AND NEIGHBOURING} HILLS.

\section{NON-STRATIFIED ROCKS.}

1. Milk quartz with a resino-vitrous lustre and with the cleavage of the rhomboedron very distinct, found near Chivela.

2. Decomposed granite near the Hacienda de Tarifa.

3. Granite found in the descent from the Portillo de Tarifa to the plain of the Venta de Chicapa.

4. Granite boulders in the upper course of the Coatzacoalcos.

5. Syenite also in boulders in the same spot.

6. Syenite at the foot of the Sierra, at little less than midway from Niltepee to Zanatepec.

7 Dioritic prophyry, or porphyritic greenstone, in the descent from Guichilona to Chihuitan.

8. Hypersthene rock found in the heights which surround the source of the stream Zopiluapa, cutting at intervals the calcareous rock.

9. Antique porphyry with crystals of felspar, tinted with chlorite and ferruginous clay from the hillock of Guichicovi.

10. Claystone porphyry from the summit of Cerro Atravesado.

11. Magnetic iron ore from the hills of Niltepec.

\section{STRATIFIED ROCKS.}

12. Quartz rock found in the descent from the Portillo of Tarifa to the Rancho de la Agua Escondida.

13. Quartz of a chipped texture from the Paso del Ostuta, on the road to Zanatepec.

14. Quartz breccia, resting on the porphyry in the summit of the Cerro Atravesado. 
15. Greenstone schist, hornblende rock of Lyell, peak of Guiévixia.

16. Grey-wacke schist; descent from Guichilona to Chihuitan.

17. Grey-wacke from the hills of Barrio.

18. Clay-slate, with the appearance of pearl-stone resting on the quartz in the summit of the Cerro de Espinosa.

19. Clay-slate from the Portillo de Tarifa.

20. Clay-slate found in the descent from the Portillo to the plains of the Venta.

21. Clay-slate, also with the appearance of pearl-stone on the summit of Paso Partida.

22. Clay-slate, in the gap between the above-named hill and that of Convento, on the road from Tarifa to San Miguel Chimalapa.

23. Clay-slate on a hill on the road from 'Tarifa to the Cienaguilla.

24. Greenstone schist found in the summit of Palo Blanco, mixed with fragments of quartz.

25. Greenstone schist in the pass of the Chicapa, near the Rancho of Puerta Vieja, on the road from the Venta to San Miguel.

26. Greenstone schist from the heights of the Upper Chicapa.

27. Greenstone schist changing to dioritic from the ascent to San Miguel Chimalapa.

28. Grey-wacke schist from the hills between the river Malatengo and the ancient estate of Xochiapa, on the road to Boca de Monte.

29. Talcose schist from the brow of the Sierra, in the ascent from Niltepec to the Cerro Atravesado.

30. Clay-slate from the foot of the Sierra, half-way between Niltepec and Zanatepec.

31. $a$ and $b$ clay-slate and talcose schist from the banks of the Upper Ostuta.

32. Dolomite limestone found in a hillock at the foot of the hills of Laollaga.

33. Compact limestone, with veins of calcareous spar, found near the slate in the neighbourhood of the Rancho del Zapotal.

34. Compact limestone which breaks into thin sheets in the descent from the Portillo to the plains of the Venta.

35. Calc tuff? from the same spot.

36. Compact limestone, and occasionally stinkstone, with veins of pearl-spar, from the Convento Chico.

37. Compact limestone of the Convento Grande : in one of the pieces there is a vein of calcareous spar, with fragments of diorite.

38. Quartzose sandstone from Daniguiati.

39. Argillaceous sandstone from Guievichi.

40. Sandstone, partly quartzose and partly argillaceous, near the estate of Chivela.

41. Sandstone schist from the table-land of Tarifa:

42. Sandstone from the foot of the small hill of Guievixia.

43. Sandstone from the Piedra Parada of Daningadchi.

44. Argillaceous sandstone from the foot of the Sierra, halfway between Niltepec and Zanatepec.

45. Claystone which may change to jasper, on the road to Santa Maria Climalapa, between the river Escolapa and the Chocolate. 
46. Jasper found in boulders in a strand of the Upper Coatzacoalcos.

47. Argillaceous stone in layers, little inclined, resting on the porphyry, No.9.

48. Guigosina stone.

49. Calcareous stone with a circular design, found on the brow of the hills of Masahua, in the source of the stream Tolistoco.

50. Calcareous stone with cavities, resting upon another similar to that on the Cerro del Convento.

51. Variegated marls resting upon sandstone, on a hillock near the Hacienda de la Chivela.

52. Earthy marls, taken from a cavity in the calcareous rock in the ascent to the Portillo de la Chivela.

53. Common marl lying over the sandstone, No 38 .

54. Calcareous breccia on the road from the Venta to San Miguel.

55. Pearl-stone breccia, found in loose fragments in the stream followed in going from Zanatepec to the Upper Ostuta.

56. Lamellar specular iron ore, from the neighbourhood of Tarifa.

\section{BANKS OF THE RIVER COATZACOALCOS.}

57. Sandstone with a base of ferruginous clay, from above the confluence of the river Chimalapilla.

58. Greenstone rock, from a rapid a little before Angostura.

59. Metamorphic, or primary limestone, from the bank of the river a little below the mouth of the Malatengo.

60. Decomposed granite, from the great rapid below the old landing place of Mal Paso.

61. Clay from the small hills on the banks of the river in its lower course: $a$ from the hill of Oajaquena ; $b$ from that of Churriagao ; $c$ from that of Penas Blancas.

62. Clay in layers, alternating with others of sand at Juchitan, 12 metres below the alluvial soil which covers the plain.

63. Calc tuff, from the margin of the fountain of Agua Caliente.

\section{HILLS NEAR THE LAGOONS AND ISLANDS IN THE UPPER LAGOON.}

64. Grey-wacke, very finely grained, of the island of Iguana or Mitiacix.

65. Porphyry with basis of jasper, from the Mitiacxocuen.

66. Porphyry with basis of argillaceous stone, from the summit of the hillock of Potrero.

67. Trachitic porphyry with small veins of calcedony, from Danigu.

68. Conglomerate of argillaceous base, from the small ravine of Chico Zapote or Endedchina, near to Danigu.

69. Jasper, from the small heights near those of the Potrero.

70. Dioritic porphyry, of the Manguixtiac.

71. Porphyry from the summit of Umalalang.

72. Syenitic greenstone from the island of Monapostiac, in large separate pieces.

73. Stratified greenstone, from Natartiac or Cerro Prieto. 


\section{8}

74. Fine grained granite in veins from the same hill, intersecting the former rock.

75. Greenstone from the same, resembling basalt, and taken from near the veins.

76. Greenstone with veins of tremolite, from the hill of Santa Teresa or Huaxtoco.

77. $a$ Greenstone from the hill near to the Hacienda de Santa Teresa, intersected by veins of the granite $b$.

78. Conglomerate of fragments of greenstone from the brow of the Umalalang.

79. Argillaceous conglomerate, from the foot of the southern slope of the $\mathrm{Ma}$ loxuet.

80. Prase, found under the slate in the same hill.

81. Grey-wacke, from the small hill of Umalpotate at the foot of the former.

\section{SIERRA DEL MORRO, AND HILLS NEAR TEHUANTEPEC, HUILOTEPEC, AND SAN FRANCISCO.}

82. $a$, Ancient porphyry, with veins $b$ of red iron and hidrate of iron, from the Cerro de la Cueva.

83. $a$ and $b$, The same porphyry also, with veins from the Cerro del Morro.

84. Dioritic porphyry, intersected by veins of sienite $b$, from the Cerro del Tigre or Daniguibedchi.

85. Finely-grained sienite, from the hills of San Diego.

86. Sienite and another rock, composed of quartz and albite, from the Huilotepec or Daniguibixo.

87. Graphic granite of the hills of Huazontlan.

88. Veins of Porphyry, altered by the fire of the hills of the Morro.

89. $a$, Dioritic porphyry of the Baxmumbah; $b$, granite from a fragment which intersects and partly covers the dioritic porplyyry; $c$, new granite in veins which intersect the two pervious rocks.

90. Gianite and sienite from the Malnagirastiac. 


\section{c. \\ ST A T IS TICS.}

TABLE No. 1.

Notice of the towns and villages in the southern division of the Isthmus of Tehuantepec, with their respective census, from the account furnished to Don Pedro de Garay by the Prefect of that district.

Names of the towns and villages.

Census.

Tehuantepec-town

8934

1. Santa Catalina Mistequilla . . . . . 247

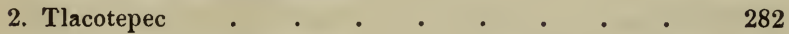

3. Santiago Laollaga '. . . . . . . 152

4. Santo Domingo Chihuitan . . . . . 532

5. San Gerónimo $\quad$ • $\quad$ • $\quad$ • $\quad$ • $\quad$ • 805

6. Itztaltepec . . . . . . . . 1546

7. Espinal . . . . . . . . 504

8. Juchitan . . . . . . . . 4567

9. Huilotepec . • . . . . . . 185

10. San Mateo del mar . . . . . . 1500

11. Santa Maria del mar . . . . . . 148

12. San Dionisio del mar . . . . . . 888

13. San Francisco del mar . . . . . . 287

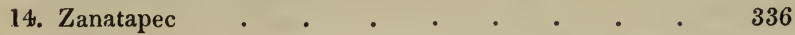

15. Niltepec . . . . . . . . 626

16 Tapanatepec . . . . . . . . 321

17. San Miguel Chimalapa . . . . . . 318

18. Santa Maria Chimalapa . . . . . . 524

19. Santa Maria Petapa . . . . . . 1447

20. Santo Domingo Petapa . . . . . . 626

21. Barrio de la Soledad . . . . . . $\quad$ • 999

22. San Juan Guichicovi . . . . . . 5000

23. San Gabriel Boca de Monte . . . . . 71

30845

Note.-In the census of the above places, the number of inlabitants of the haciendas (estates) and ranchos (settlements) of their respective jurisdictions (Table No. 2.) has been included. 
TABLE No. 2.

Notice of the principal haciendas and ranchos of the southern division of the Isthmus of Tehuantepec, and of the number of horn cattle in each, calculated from the most authentic information which Don Pedro de Garay was able to obtain.

\begin{tabular}{l}
$\begin{array}{l}\text { Names of the haciendas } \\
\text { and ranchos. }\end{array}$ \\
\hline
\end{tabular}


TABLE No. 3.

Notice of the towns and villages of the northern division of the Isthmus of Tehuantepec, their respective census and the number of head of cattle in each, according to the data furnished by the statistics of the state of Vera Cruz, published in 1831 .

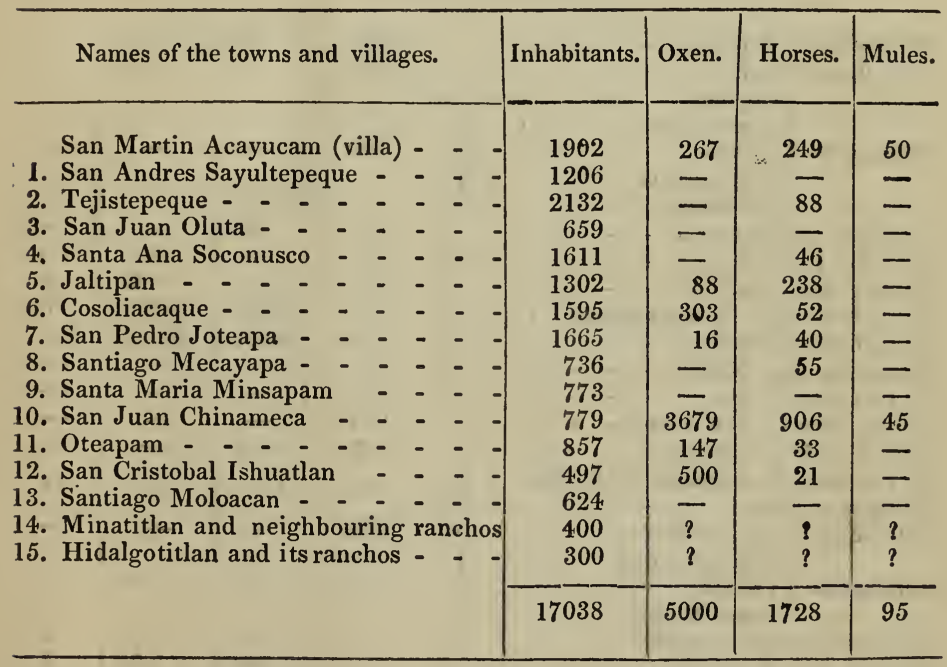


TABLE No. 4.

Notice of the haciendas and rancherias in the northern division of the Isth mus of Tehuantepec, with their census and number of head of cattle respectively, from the data furnished by the statistical account of the state of Vera Cruz, published in 1831 .

\begin{tabular}{|c|c|c|c|c|c|c|c|}
\hline \multicolumn{4}{|l|}{ Names. } & \multirow{2}{*}{ Inhabitants. } & \multirow{2}{*}{ Oxen. } & \multirow{2}{*}{ Horses. } & \multirow{2}{*}{ Mules. } \\
\hline Rancheria de Michapa - & - - & - & - - & & & & \\
\hline $\begin{array}{c}\text { Idem del Encinal - - - } \\
\text { Coyote }\end{array}$ & - & - & - & 382 & - & 35 & - \\
\hline Rancherias $\left\{\begin{array}{l}\text { Guellapam } \\
\text { Jalapa } \\
\text { Cosaguilapa } \\
\text { Lechonal }\end{array}\right.$ & & & & 450 & - & 一 & - \\
\hline Hacienda del Pedregal - & - & - & - - & 20 & 100 & - & - \\
\hline Idem del Calabozo - - & $-\quad-$ & - & $-\quad-$ & 63 & - & - & - \\
\hline Id. de Santa Catalina - & $-\quad-$ & - & - - & 210 & 1000 & 10 & 2 \\
\hline Id. de San Juan B. Nopala & pam & - & - - & 435 & 30000 & 4000 & 180 \\
\hline Id. de Cuatotolapam - - & - & - & - & 716 & 19000 & 4000 & 285 \\
\hline Rancheria de la Malota - & - & - & - & 287 & - & - & - \\
\hline Id. de Corral Viejo - - & $-\quad-$ & - & - & 81 & - & - & - \\
\hline Id. del Paso de San Juan & - & - & - & 264 & - & - & - \\
\hline Hacienda de Solcuautla - & - & - & - & 123 & 5000 & - & 一 \\
\hline $\begin{array}{l}\text { Id. de Santa Catalina de lo } \\
\text { Id. de San Felipe }\end{array}$ & $\begin{array}{l}\text { s Ortiz } \\
-\quad-\end{array}$ & es & $-\}$ & 133 & 1300 & 360 & 18 \\
\hline $\begin{array}{l}\text { Rancheria de los Quemados } \\
\text { (Camahuacapa }\end{array}$ & - & - & & 254 & 一 & 一 & 一 \\
\hline Rancherias $\left\{\begin{array}{l}\text { Correa } \\
\text { Casas Viejas }\end{array}\right.$ & & & & 165 & 513 & 73 & - \\
\hline Hacienda de los Almagres & $-\quad-$ & - & & 49 & 2200 & 200 & 8 \\
\hline Idem de San Antonio - & - - & - & - & 9 & 400 & 90 & 4 \\
\hline Id. de San José Teposapa & $-\quad-$ & - & $-\quad-$ & 7 & 2400 & 10 & 2 \\
\hline & & & & 3973 & 62143 & 8938 & 499 \\
\hline
\end{tabular}


TABLE No. 5.

Summary of the statistical notices respecting the number of inhabitants and head of cattle in the Isthmus of Tehuantepec.

\begin{tabular}{|c|c|c|c|c|c|}
\hline \multirow{2}{*}{\multicolumn{2}{|c|}{ Divisions. }} & Population. & \multicolumn{3}{|c|}{ Cattrle. } \\
\hline & & Inhabitants. & Oxen. & $\begin{array}{c}\text { Horses } \\
\text { and mules. }\end{array}$ & Sheep. \\
\hline Southern part of the & Isthmus & 30,845 & 44,135 & 11,260 & 1500 \\
\hline Northern part & $-\quad-$ & 21,011 & 67,143 & 25,000 & 230 \\
\hline Total & $-\quad-$ & 51,856 & 111,278 & 36,260 & 1730 \\
\hline
\end{tabular}

Note., In all the proper names of places mentioned in the preceeding Report whenever the letter $x$ occurs it onght to be pronounced as the French $c h$, or the English $s h$, this sound having been expressed by an $x$ in all the Mexican dictionaries from the period of the conquest. 


\section{D.}

\section{TABLE OF DISTANCES.}

\section{OBSERVATIONS.}

The following lengths of routes are calculated for the voyages of sailing vessels. It was obviously impossible to give at one view the differences of their duration which must vary according to a vessel being either a Collier or a swift Man of War.

To establish a comparison it was necessary to adopt some one point of departure, and the Lizard has been assumed from the West of Europe, it being evident that for all vessels passing the British Channel, the differences of distances in this table will still hold good; and the same may be said as to results for those leaving France and the Peninsula.

These voyages have been calculated on the courses, vessels would be compelled to take in consequence of the trade winds on both sides of the Equinoxial Line. For places within the Straits of Sunda the parallel of 41 South Latitude has been kept as far as the Longitude of the Island of St. Pauls, before making for Java-head.

The voyages touching at the Cape of Good Hope have not been given, because, although the distances drawn from point to point upon a Globe would by that route appear to be less, still it is well known that they would really employ the most time in beating against the trade winds.

As vessels from England now outward bound to China take but little cargo or passengers, they have sufficient spare room for provisions and fuel, and therefore they need not touch anywhere before reaching the China Sea. But this is not the case with Emigrant Ships to Australia and New Zealand; and vessels bound to these places can scarcely dispense with calling at Rio Janeiro both for the health and comfort of the passengers, as well as for revictualling.

From Europe to the Gulf of Mexico it has been supposed most convenient to touch first at the Island of St. Thomas, and then of course the voyage will be calling at Jamacia, and then round the Peninsula of Yucatan to the Coatzacoalcos.

St. Thomas has also been taken as the best point to make, for vessels from New York to the Gulf of Mexico; for although to the North of Cuba would appear to be much the shortest route, yet the difficulties of the Bahamas for large vessels, and the constant adverse current of the Gulf-stream, would still cause this last to be the most unfavourable in respect to time and safety.

It will be seen that for outward bound ships, the route through the Isthmus would in every instance be accomplished in the shortest time, going before favourable trade winds on both sides of the Line. 


\section{TABLE OF DJSTANCES}

To the principal Ports in the Pacific and Indian Oceans, compared with the Voyages to the same places via the Isthmus of T'ehuantepec.

\begin{tabular}{|c|c|c|c|c|}
\hline No. & VOYAGE. & $\begin{array}{l}\text { Distance } \\
\text { Nau. miles. }\end{array}$ & $\begin{array}{l}\text { Distance } \\
\text { via the } \\
\text { Isthmus. }\end{array}$ & $\begin{array}{l}\text { Difference } \\
\text { saved. }\end{array}$ \\
\hline 1 & $\begin{array}{l}\text { Lizard to the Isthmus of Tehuantepec, } \\
\text { touching at St. Thomas, Jamaica, round } \\
\text { Yucatan to the Coatzacoalcos - - - } \\
\text { Across the Isthmus to Bocabarra - - }\end{array}$ & $\begin{array}{r}5210 \\
150 \\
\end{array}$ & 5360 & \\
\hline 2 & $\begin{array}{l}\text { Lizard to Bocabarra, round Cape Horn, } \\
\text { touching at Madeira, Rio Janeiro, Val- } \\
\text { paraiso and Callao - - - - }\end{array}$ & 11,820 & 5360 & 6460 \\
\hline 3 & $\begin{array}{l}\text { Lizard to the Columbia River, by Cape Horn } \\
\text { to Bocabarra No. 2. } \\
\text { Bocabarra to Columbia River - }\end{array}$ & $\begin{array}{r}11,820 \\
2320\end{array}$ & & \\
\hline & & 14,140 & 7680 & 6460 \\
\hline 4 & $\begin{array}{l}\text { Lizard to Tahiti, round Cape Horn, touch- } \\
\text { ing at Madeira, Rio Janeiro and Valpa- } \\
\text { raiso }-{ }_{-}\end{array}$ & 12,830 & 9170 & 3660 \\
\hline 3 & $\begin{array}{l}\text { Lizard to Wellington, New Zealand, round } \\
\text { Cape Horn, touching at Valparaiso and } \\
\text { Tahiti - - - }\end{array}$ & 15,160 & 11,500 & 3660 \\
\hline 6 & $\begin{array}{l}\text { Lizard to Wellington, round Cape Horn, } \\
\text { direct from Valparaiso }\end{array}$ & 13,990 & 11,500 & 2490 \\
\hline 7 & $\begin{array}{l}\text { Lizard to Wellington, by the Atlantic and } \\
\text { Indian Oceans, touching at Madeira, Rio } \\
\text { Janeiro, to Lat. } 41 \text { S., and thence east- } \\
\text { ward - - - }\end{array}$ & 15,820 & 11,500 & 4320 \\
\hline 8 & $\begin{array}{l}\text { Lizard to Wellington, touching at Madeira } \\
\text { only, and crossing the equinoxial line in } \\
\text { Long. } 26 \mathrm{~W} \text {. }\end{array}$ & 14,740 & 11,500 & 3240 \\
\hline 9 & $\begin{array}{l}\text { Lizard to Sandwich Islands, via the Isthmus } \\
\text { to Bocabarra, No. 1. - } \\
\text { Bocabarra to Sandwich Islands }\end{array}$ & $\begin{array}{l}5360 \\
3500 \\
-\end{array}$ & 8860 & \\
\hline 10 & $\begin{array}{l}\text { Lizard to Sandwich Islands, via Cape Horn, } \\
\text { touching at Valparaiso }\end{array}$ & 14,300 & 8860 & 5440 \\
\hline 11 & $\begin{array}{l}\text { Lizard to Canton, via the Isthmus to Sand- } \\
\text { wich Islands, No. } 9 \text { - }- \\
\text { Sandwich Islands to Canton }\end{array}$ & $\begin{array}{l}8860 \\
5120 \\
\end{array}$ & 13,980 & \\
\hline
\end{tabular}


Table of Distances continued.

\begin{tabular}{|c|c|c|c|c|}
\hline No. & VOYAGE. & $\begin{array}{c}\text { Distance } \\
\text { Nau. miles. }\end{array}$ & $\begin{array}{l}\text { Distance } \\
\text { via the } \\
\text { Isthmus. }\end{array}$ & $\begin{array}{l}\text { Difference } \\
\text { saved. }\end{array}$ \\
\hline 12 & $\begin{array}{l}\text { Lizard to Canton, touching at Madeira, } \\
\text { crossing the Line in Long. } 26 \mathrm{~W} \text {. going to } \\
\text { Lat. } 41 \mathrm{~S} \text {, and Eastward to Long. of St. } \\
\text { Paul's, and thence by the Straits of Sunda }\end{array}$ & 14,750 & 13,980 & 770 \\
\hline 13 & $\begin{array}{l}\text { Lizard to Canton, touching at Madeira and } \\
\text { Rio Janeiro - }\end{array}$ & 15,830 & 13,980 & 1850 \\
\hline 14 & $\begin{array}{l}\text { Lizard to Manila (same route as No. } 12 \text { to } \\
\text { the Straits of Sunda) }\end{array}$ & 14,210 & 13,630 & 580 \\
\hline 15 & Lizard to Manila, touching at Rio Janeiro - & 15,290 & 13,630 & 1660 \\
\hline 16 & $\begin{array}{l}\text { New York to Bocabarra, round Cape Horn } \\
\text { crossing the Line in Long. 26 W., Rio } \\
\text { Janeiro, Valparaiso, Callao, and Boca- } \\
\text { barra - - - - }\end{array}$ & 12,390 & 3330 & 9060 \\
\hline 17 & $\begin{array}{l}\text { New York to Canton, by the Atlantic and } \\
\text { Indian Oceans, crossing the Line in } \\
\text { Long. } 26 \text { W., and the same course as in } \\
\text { No. } 12-\end{array}$ & 15,540 & 11,950 & 3590 \\
\hline 18 & $\begin{array}{l}\text { New Orleans to Bocabarra, round Cape } \\
\text { Horn, to St. Thomas, Rio Janeiro, Valpa- } \\
\text { raiso, Callao, and Bocabarra }\end{array}$ & 12,510 & 900 & 11,610 \\
\hline 19 & $\begin{array}{l}\text { New Orleans to Columbia River, round Cape } \\
\text { Horn - }-\end{array}$ & 14,830 & 3220 & 11,610 \\
\hline 20 & $\begin{array}{c}\text { New Orleans to the Columbia River-inland } \\
\text { journey-up the Mississippi, up the Mis- } \\
\text { souri and across the Rocky mountains } \\
\text { Note-This has a land journey of } 900 \text { miles full } \\
\text { of difficulties. }\end{array}$ & 3400 & 3220 & 180 \\
\hline 21 & $\begin{array}{l}\text { Jamaica to the Columbia River via the Isth- } \\
\text { mus of Tehuantepec- } \\
\text { In favour of New Orleans the difference } \\
\text { of }-\end{array}$ & & 3530 & 310 \\
\hline 22 & $\begin{array}{l}\text { New York to the Columbia River via the } \\
\text { Isthmus of Tehuantepec } \\
\text { Jamaica to the same } \\
\text { In favour of Jamaica the difference of }\end{array}$ & & $\begin{array}{r}5650 \\
3530 \\
-10\end{array}$ & 2120 \\
\hline
\end{tabular}

Consequently in favour of the British Establishments in the West Indies ; and also for a British settlement in the Isthmus of Tehuantepec for the whole trade of the China seas, the West Coasts of both the Americas, and over the great Pacific Ocean. 


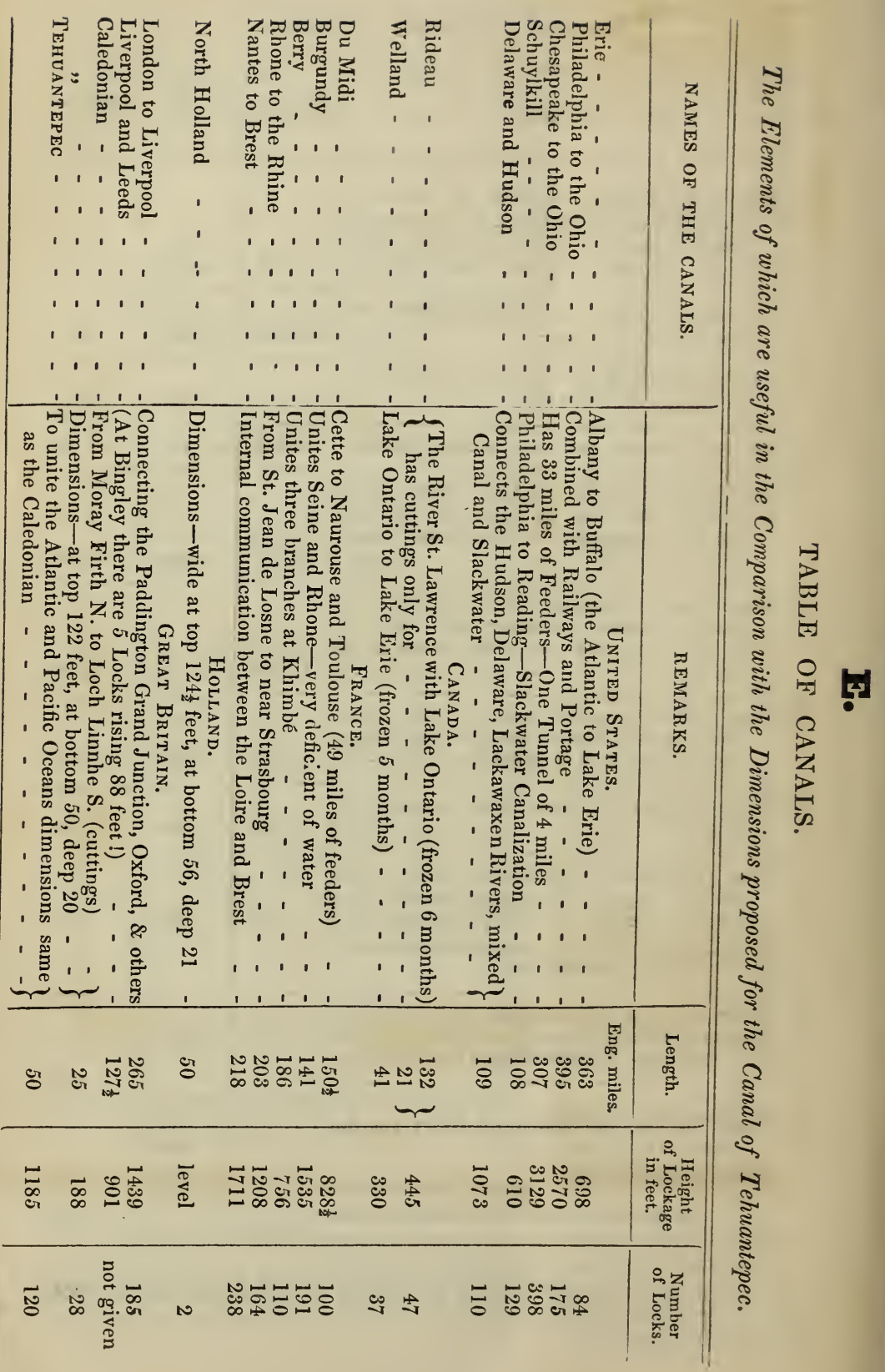




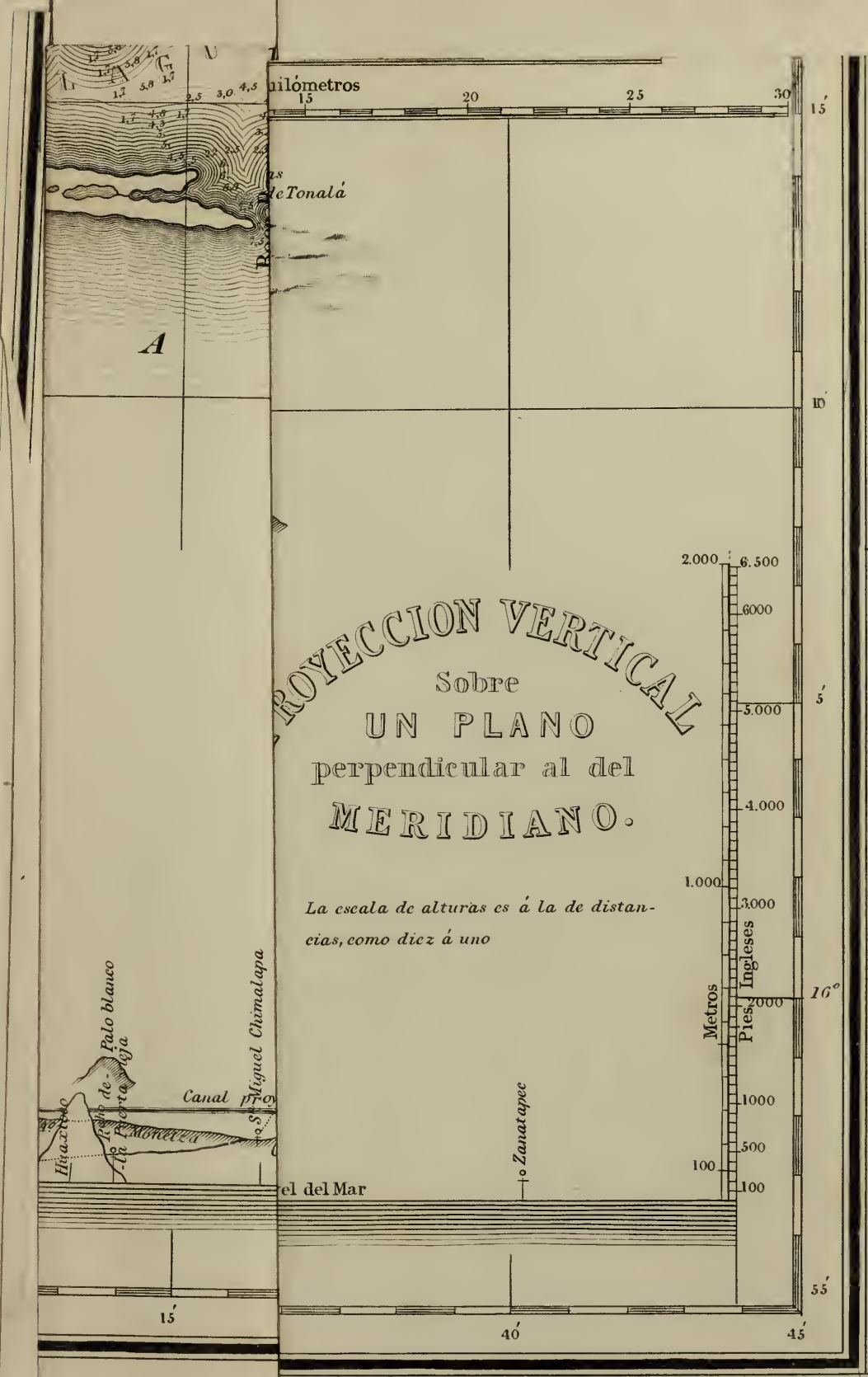




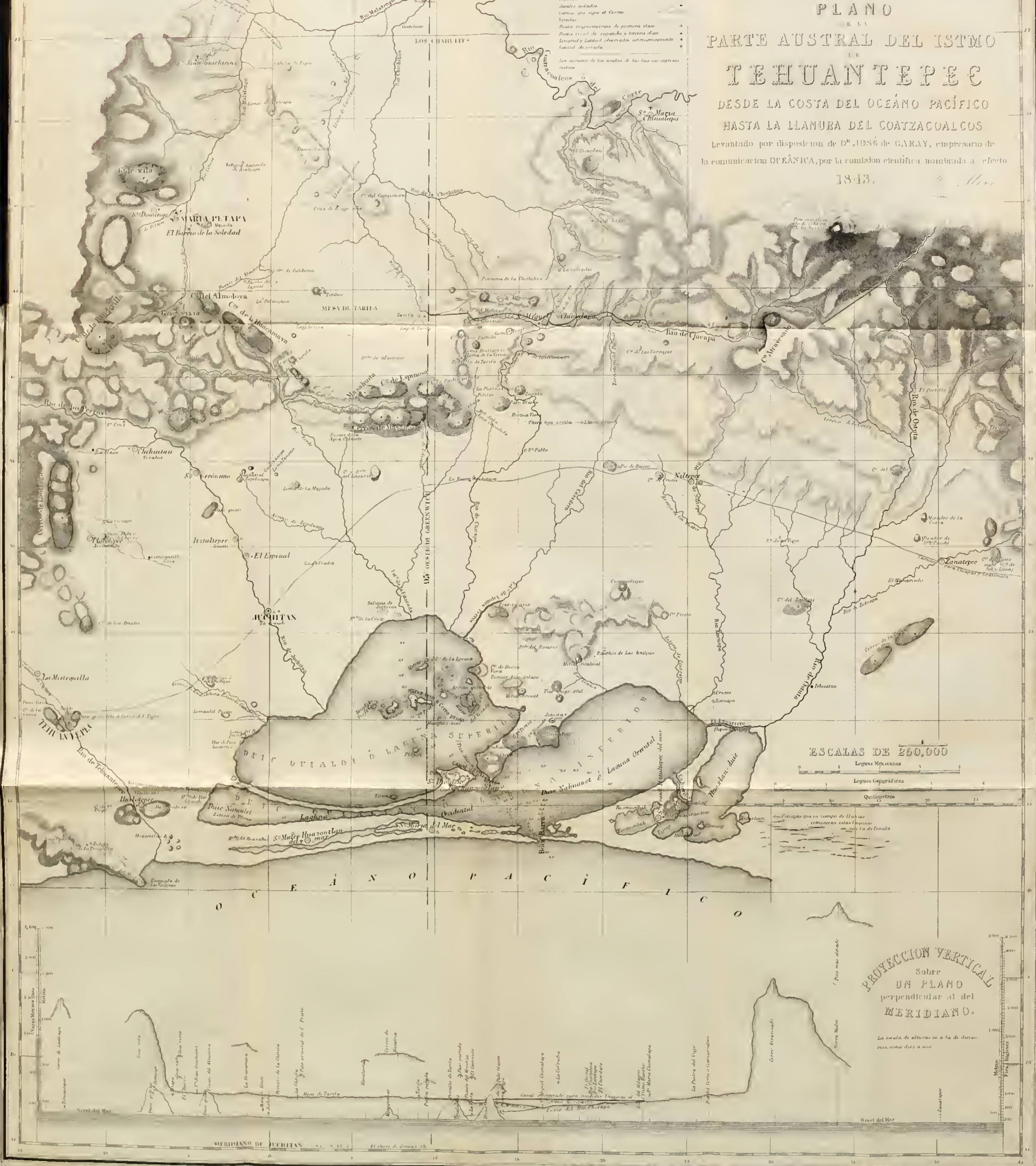





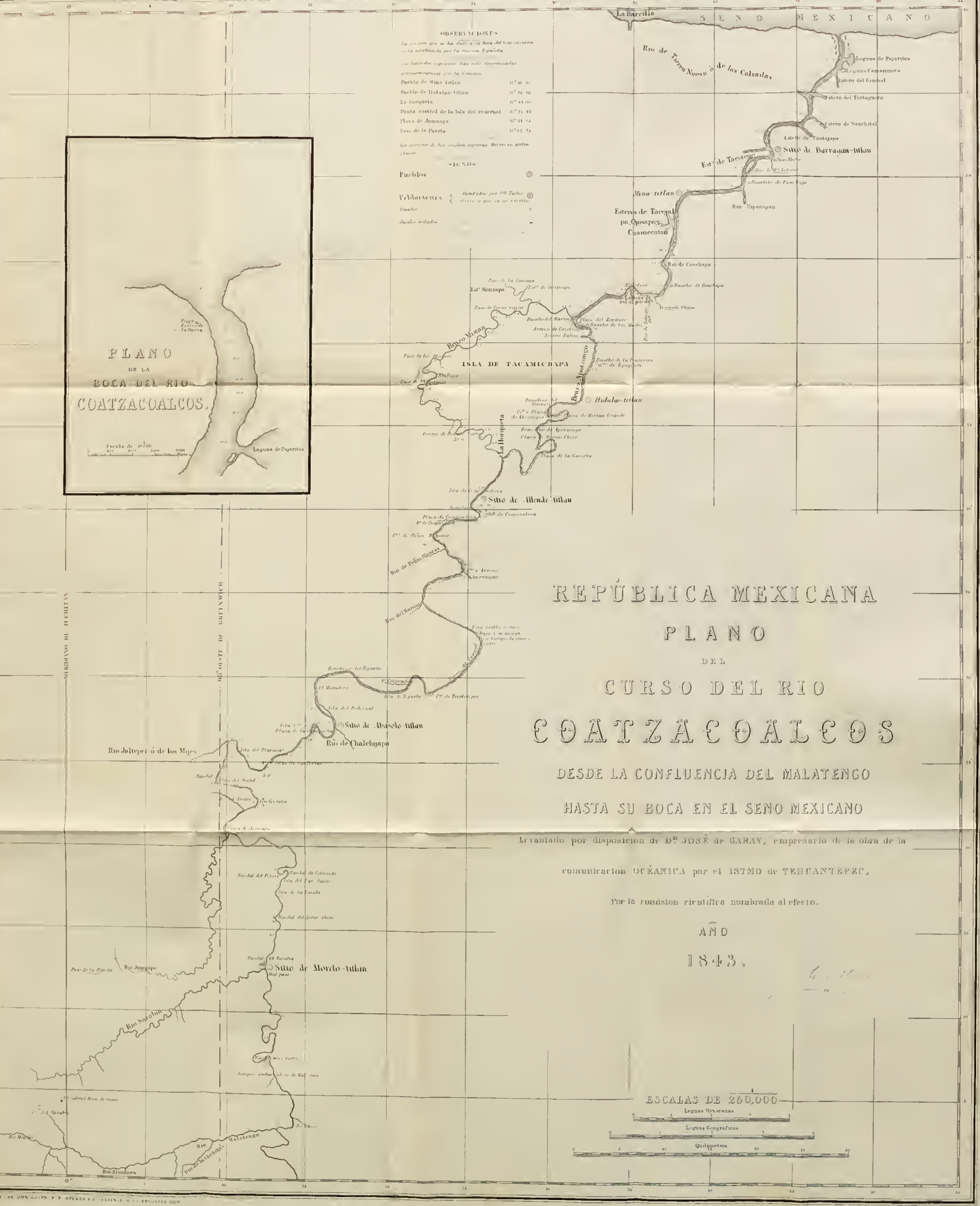


- 


UNIVERSITY OF ILLINOIS-URBANA

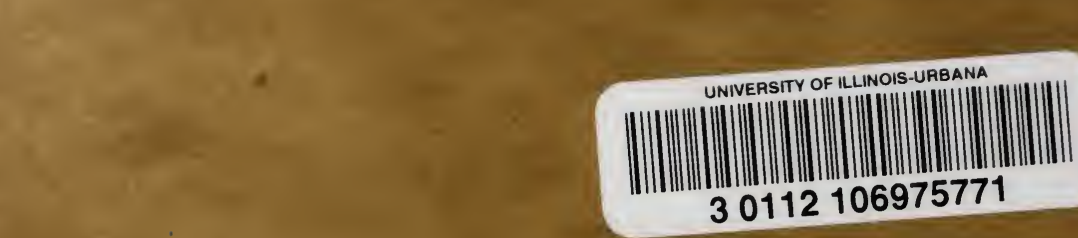

30112106975771 